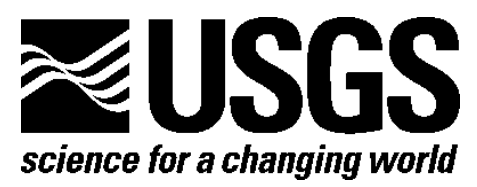

Prepared in cooperation with the U.S. Department of Defense Task Force for Business and Stability Operations and the Afghanistan Geological Survey

\title{
Characterization of Potential Mineralization in Afghanistan: Four Permissive Areas Identified Using Imaging Spectroscopy Data
}

Open-File Report 2014-1071 
Prepared in cooperation with the U.S. Department of Defense Task Force for Business and Stability Operations and the Afghanistan Geological Survey

\section{Characterization of Potential Mineralization in Afghanistan: Four Permissive Areas Identified Using Imaging Spectroscopy Data}

By Trude V.V. King, Byron R. Berger, and Michaela R. Johnson

Open-File Report 2014-1071 


\section{U.S. Department of the Interior \\ SALLY JEWELL, Secretary}

\section{U.S. Geological Survey \\ Suzette M. Kimball, Acting Director}

U.S. Geological Survey, Reston, Virginia: 2014

For more information on the USGS-the Federal source for science about the Earth,

its natural and living resources, natural hazards, and the environment-visit

http://www.usgs.gov or call 1-888-ASK-USGS

For an overview of USGS information products, including maps, imagery, and publications, visit $h$ ttp://www.usgs.gov/pubprod

To order this and other USGS information products, visit http://store.usgs.gov

Suggested citation:

King, T.V.V., Berger, B.R., and Johnson, M.R., 2014, Characterization of potential mineralization in Afghanistan: Four permissive areas identified using imaging spectroscopy data: U.S. Geological Survey Open-File Report 2014-1071, 67 p., http://dx.doi/org/10.3133/ofr20141071.

ISSN 2331-1258 (online)

Any use of trade, firm, or product names is for descriptive purposes only and does not imply endorsement by the U.S. Government.

Although this information product, for the most part, is in the public domain, it also may contain copyrighted materials as noted in the text. Permission to reproduce copyrighted items must be secured from the copyright owner. 


\section{Contents}

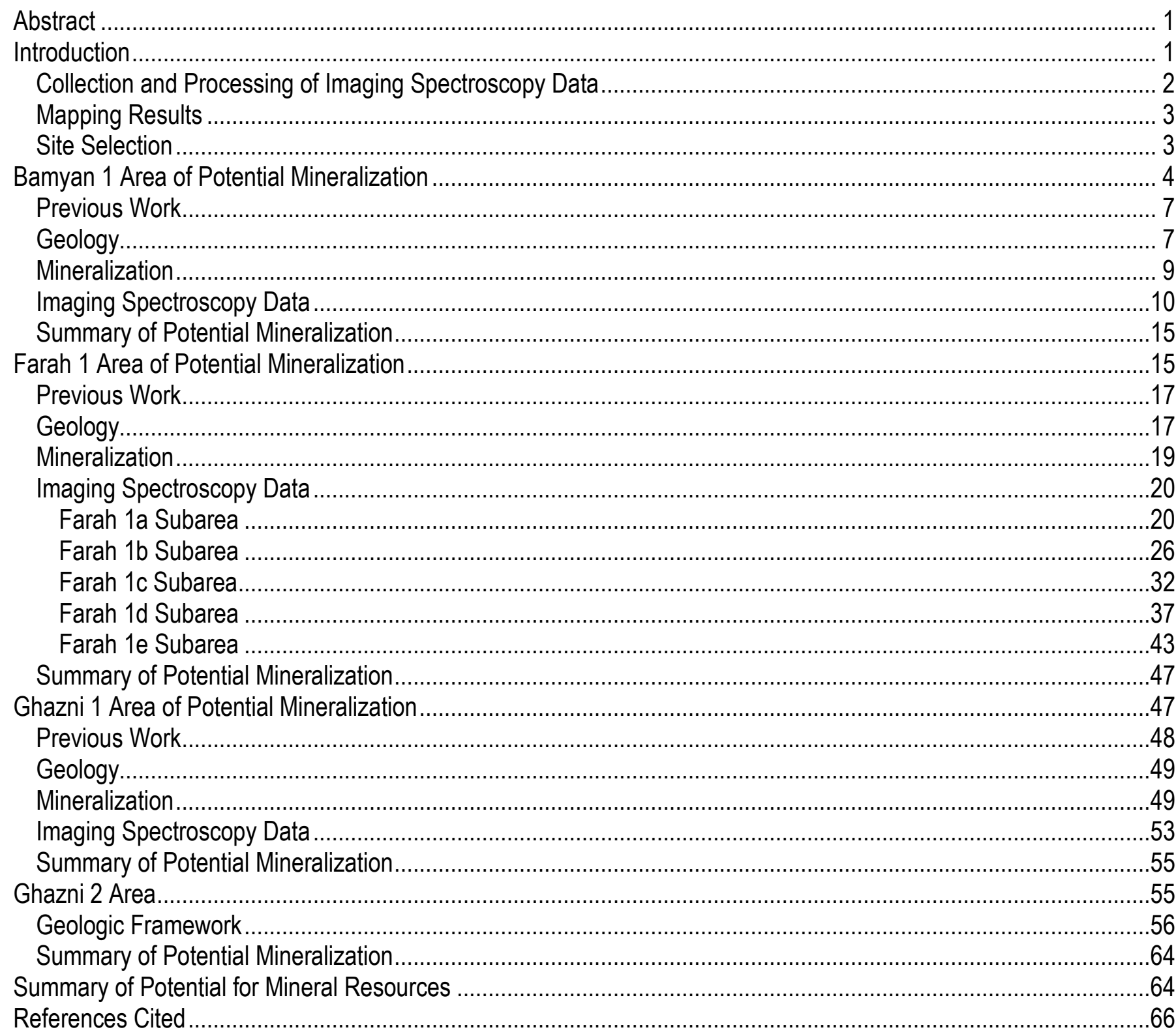

\section{Figures}

Figure 1. Location map showing the four areas of potential mineralization in Afghanistan discussed in the report: Bamyan 1, Farah 1, Ghazni 1, and Ghazni 2

Figure 2. Location of the Bamyan 1 area in Afghanistan

Figure 3. Geologic framework map of the Bamyan area including the Bamyan 1 area in Afghanistan (Abdullah and Chmyriov, 1977; Abdullah and others, 1977; Doebrich and Wahl, 2006). Map includes locations of thermal springs (Abdullah and others, 1977)....

Figure 4. Geologic map of the Bamyan 1 area in Afghanistan shown as a red box on Figure 3 (Abdullah and

Chmyriov, 1977; Abdullah and others, 1977; Doebrich and Wahl, 2006) 
Figure 5. Map of iron-bearing minerals and other materials derived from HyMap ${ }^{\mathrm{TM}}$ data in the Bamyan 1 area in Afghanistan (King and others, 2011b; Kokaly and others, 2013)

Figure 6. Map of carbonates, phyllosilicates, sulfates, altered minerals, and other materials derived from HyMap $^{\text {TM }}$ data in the Bamyan 1 area in Afghanistan (Kokaly and others, 2011, 2013) ....

Figure 7. Map showing common alteration minerals derived from HyMap ${ }^{\mathrm{TM}}$ data in the Bamyan 1 area in Afghanistan (Kokaly and others, 2011, 2013). The detection of common alteration minerals is suggestive of possible past mineralization processes

Figure 8. A three-dimensional image showing common alteration minerals derived from HyMap ${ }^{\mathrm{TM}}$ data overlain on a digital elevation model (Davis, 2007) in the Bamyan 1 area in Afghanistan (Kokaly and others, 2011, 2013).... 14

Figure 9. Location of the Farah 1 area with five subareas $(a, b, c, d$, and $e)$ in Afghanistan.............................. 16 Figure 10. Geologic map of the Farah 1 area in Afghanistan (Abdullah and Chmyriov, 1977;Abdullah and

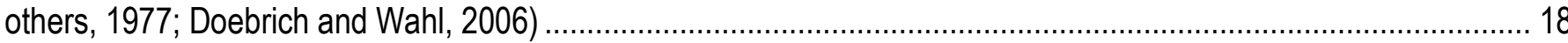

Figure 11. Map of carbonates, phyllosilicates, sulfates, altered minerals, and other materials derived from HyMap $^{\text {TM }}$ data in the Farah 1 area in Afghanistan (Kokaly and others, 2011, 2013)

Figure 12. Map showing common alteration minerals derived from HyMap ${ }^{\mathrm{TM}}$ data in the Farah 1 area in Afghanistan (Kokaly and others, 2011, 2013). The detection of common alteration minerals is suggestive of possible past mineralization processes

Figure 13. Map of carbonates, phyllosilicates, sulfates, altered minerals, and other materials derived from HyMap $^{\mathrm{TM}}$ data in the Farah 1a subarea in Afghanistan (Kokaly and others, 2011, 2013).....

Figure 14. Geologic map of the Farah 1a subarea in Afghanistan (Abdullah and others, 1977; Doebrich and Wahl, 2006)....

Figure 15. Map of iron-bearing minerals and other materials derived from HyMap ${ }^{\mathrm{TM}}$ data in the Farah 1a subarea in Afghanistan (King and others, 2011b; Kokaly and others, 2013). The data for the extreme left side of this image were collected under adverse light conditions and have not been included in this analysis ....

Figure 16. Map of carbonates, phyllosilicates, sulfates, altered minerals, and other materials derived from HyMap $^{\mathrm{TM}}$ data in the Farah 1b subarea in Afghanistan (Kokaly and others, 2011, 2013)

Figure 17. Geologic map of the Farah 1b subarea in Afghanistan (Abdullah and Chmyriov, 1977; Abdullah and others, 1977; Doebrich and Wahl, 2006)

Figure 18. Contrast-enhanced stretch of the natural-color composite of Landsat Thematic Mapper bands from Davis (2007) of the Farah $1 \mathrm{~b}$ area in Afghanistan....

Figure 19. Map showing common alteration minerals derived from HyMap ${ }^{\mathrm{TM}}$ data in the Farah $1 \mathrm{~b}$ subarea in Afghanistan (Kokaly and others, 2011, 2013). The spectroscopic detection of common alteration minerals is suggestive of possible past mineralization processes

Figure 20. Map of iron-bearing minerals and other materials derived from HyMap ${ }^{\mathrm{TM}}$ data in the Farah $1 \mathrm{~b}$ area in Afghanistan (King and others, 2011b; Kokaly and others, 2013)....

Figure 21. Contrast-enhanced stretch of the natural-color composite of Landsat Thematic Mapper bands from Davis (2007) of the Farah 1c subarea in Afghanistan.

Figure 22. Geologic map of the Farah 1c subarea in Afghanistan (Abdullah and Chmyriov, 1977; Abdullah and others, 1977; Doebrich and Wahl, 2006)

Figure 23. Map of carbonates, phyllosilicates, sulfates, altered minerals, and other materials derived from HyMap $^{\text {TM }}$ data in the Farah 1c subarea in Afghanistan (Kokaly and others, 2011, 2013).....

Figure 24. Map of iron-bearing minerals and other materials derived from HyMap ${ }^{\mathrm{TM}}$ data in the Farah $1 \mathrm{C}$ subarea in Afghanistan (King and others, 2011b; Kokaly and others, 2013)....

Figure 25. Geologic map and known mineral occurrences in the Farah 1d subarea in Afghanistan (Abdullah and Chmyriov, 1977; Abdullah and others, 1977; Doebrich and Wahl, 2006)

Figure 26. Contrast-enhanced stretch of the natural-color composite of Landsat Thematic Mapper bands from Davis (2007) of the Farah 1d subarea in Afghanistan. The large, light-colored oblong area in the bottom half of the image is mapped as Oligocene intrusive rocks (Abdullah and Chmyriov, 1977; Doebrich and Wahl, 2006) 
Figure 27. Map of carbonates, phyllosilicates, sulfates, altered minerals, and other materials derived from HyMap $^{\mathrm{TM}}$ data in the Farah 1d subarea in Afghanistan (Kokaly and others, 2011, 2013) 40

Figure 28. Map showing common alteration minerals derived from HyMap ${ }^{\mathrm{TM}}$ data in the Farah $1 \mathrm{~d}$ subarea in Afghanistan (Kokaly and others, 2011, 2013). The detection of common alteration minerals is suggestive of possible past mineralization processes .....

Figure 29. Map of iron-bearing minerals and other materials derived from HyMap ${ }^{\mathrm{TM}}$ data in the Farah $1 \mathrm{~d}$ subarea in Afghanistan (King and others, 2011b; Kokaly and others, 2013)

Figure 30. Contrast-enhanced stretch of the natural-color composite of Landsat Thematic Mapper bands from Davis (2007) of the Farah 1e subarea in Afghanistan

Figure 31. Geologic map and known mineral occurrence of the Farah 1e subarea in Afghanistan (Abdullah and Chmyriov, 1977; Abdullah and others, 1977; Doebrich and Wahl, 2006)

Figure 32. Map of carbonates, phyllosilicates, sulfates, altered minerals, and other materials derived from HyMap $^{\mathrm{TM}}$ data in the Farah 1e subarea in Afghanistan (Kokaly and others, 2011, 2013) ...................................46

Figure 33. Location of the Ghazni 1 area in Afghanistan ........................................................................... 48

Figure 34. Contrast-enhanced stretch of the natural-color composite of Landsat Thematic Mapper bands from Davis (2007) of the Ghazni 1 area in Afghanistan

Figure 35. Geologic map and known mineral occurrences in the Ghazni 1 area in Afghanistan (Abdullah and Chmyriov, 1977; Abdullah and others, 1977; Doebrich and Wahl, 2006)

Figure 36. Map of carbonates, phyllosilicates, sulfates, altered minerals, and other materials derived from HyMap $^{\mathrm{TM}}$ data in the Ghazni 1 area in Afghanistan (Kokaly and others, 2011, 2013) .........................................52

Figure 37. Map of iron-bearing minerals and other materials derived from HyMap ${ }^{\mathrm{TM}}$ data in the Ghazni 1 area in Afghanistan (King and others, 2011b; Kokaly and others, 2013) ......................................................... 54

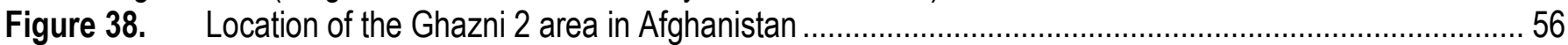

Figure 39. Geologic map and known mineral occurrences in the Ghazni 2 area in Afghanistan (Abdullah and Chmyriov, 1977; Abdullah and others, 1977; Doebrich and Wahl, 2006) ............................................................ 56

Figure 40. Contrast-enhanced stretch of the natural-color composite of Landsat Thematic Mapper bands from Davis (2007) of the Ghazni 2 area in Afghanistan.

Figure 41. Map of carbonates, phyllosilicates, sulfates, altered minerals, and other materials derived from HyMap $^{\mathrm{TM}}$ data in the Ghazni 2 area in Afghanistan (Kokaly and others, 2011, 2013).

Figure 42. Map of iron-bearing minerals and other materials derived from HyMap ${ }^{\mathrm{TM}}$ data in the Ghazni 2 area in Afghanistan (King and others, 2011b; Kokaly and others, 2013)

Figure 43. Map showing common alteration minerals derived from HyMap ${ }^{\mathrm{TM}}$ data and volcanoes in the Ghazni 2 area in Afghanistan (Kokaly and others, 2011, 2013). The detection of common alteration minerals is suggestive of possible past mineralization processes

Figure 44. A three-dimensional image showing common alteration minerals derived from HyMap ${ }^{\mathrm{TM}}$ data overlain on a digital elevation model (Davis, 2007) in the Ghazni 2 area in Afghanistan (Kokaly and others, 2011, 2013). 


\section{Conversion Factors}

\begin{tabular}{lcl}
\hline \multicolumn{1}{c}{ Multiply } & By & To obtain \\
\hline Leter $(\mathrm{m})$ & 3.281 & foot $(\mathrm{ft})$ \\
kilometer $(\mathrm{km})$ & 0.6214 & mile $(\mathrm{mi})$ \\
\hline & Area & \\
\hline square kilometer $\left(\mathrm{km}^{2}\right)$ & 0.3861 & square mile $\left(\mathrm{mi}^{2}\right)$ \\
\hline
\end{tabular}

Horizontal coordinate information is referenced to the insert datum name, World Geodetic System 1984 


\title{
Characterization of Potential Mineralization in Afghanistan: Four Permissive Areas Identified Using Imaging Spectroscopy Data
}

\author{
By Trude V.V. King, Byron R. Berger, and Michaela R. Johnson
}

\begin{abstract}
As part of the U.S. Geological Survey and Department of Defense Task Force for Business and Stability Operations natural resources revitalization activities in Afghanistan, four permissive areas for mineralization, Bamyan 1, Farah 1, Ghazni 1, and Ghazni 2, have been identified using imaging spectroscopy data. To support economic development, the areas of potential mineralization were selected on the occurrence of selected mineral assemblages mapped using the HyMap ${ }^{\mathrm{TM}}$ data (kaolinite, jarosite, hydrated silica, chlorite, epidote, iron-bearing carbonate, buddingtonite, dickite, and alunite) that may be indicative of past mineralization processes in areas with limited or no previous mineral resource studies. Approximately 30 sites were initially determined to be candidates for areas of potential mineralization. Additional criteria and material used to refine the selection and prioritization process included existing geologic maps, Landsat Thematic Mapper data, and published literature. The HyMap $^{\mathrm{TM}}$ data were interpreted in the context of the regional geologic and tectonic setting and used the presence of alteration mineral assemblages to identify areas with the potential for undiscovered mineral resources. Further field-sampling, mapping, and supporting geochemical analyses are necessary to fully substantiate and verify the specific deposit types in the four areas of potential mineralization.
\end{abstract}

\section{Introduction}

The HyMap ${ }^{\mathrm{TM}}$ imaging spectroscopy data of Afghanistan have been analyzed to detect the presence of selected minerals consistent with past mineralization processes in previously uncharacterized areas of potential mineralization (Peters and others, 2011). This study identifies four such areas: Bamyan 1, Farah 1, Ghazni 1, and Ghazni 2 (fig. 1), which have limited or no previous studies to support economic development (Peters and others, 2007). However, based on the characterization and mapping of surficial mineralogy derived from the HyMap ${ }^{\mathrm{TM}}$ data, these areas are believed to present opportunities for economic development of a number of different mineral, commodity, and deposit types and warrant further evaluation and onsite characterization. In previous studies, the U.S. Geological Survey (USGS) with support from the Department of Defense Task Force for Business and Stability Operations (TFBSO), has successfully used imaging spectrometer (hyperspectral) data (Kokaly and others, 2008, 2011; King and others, 2011b) to help evaluate opportunities for economic development of gold, silver, copper, rare earth elements, uranium, tin, iron ore, mercury, lead-zinc, bauxite, and industrial minerals at 21 study sites (Abdullah and others, 1977; Peters and others, 2011; King and others, 2011a). 


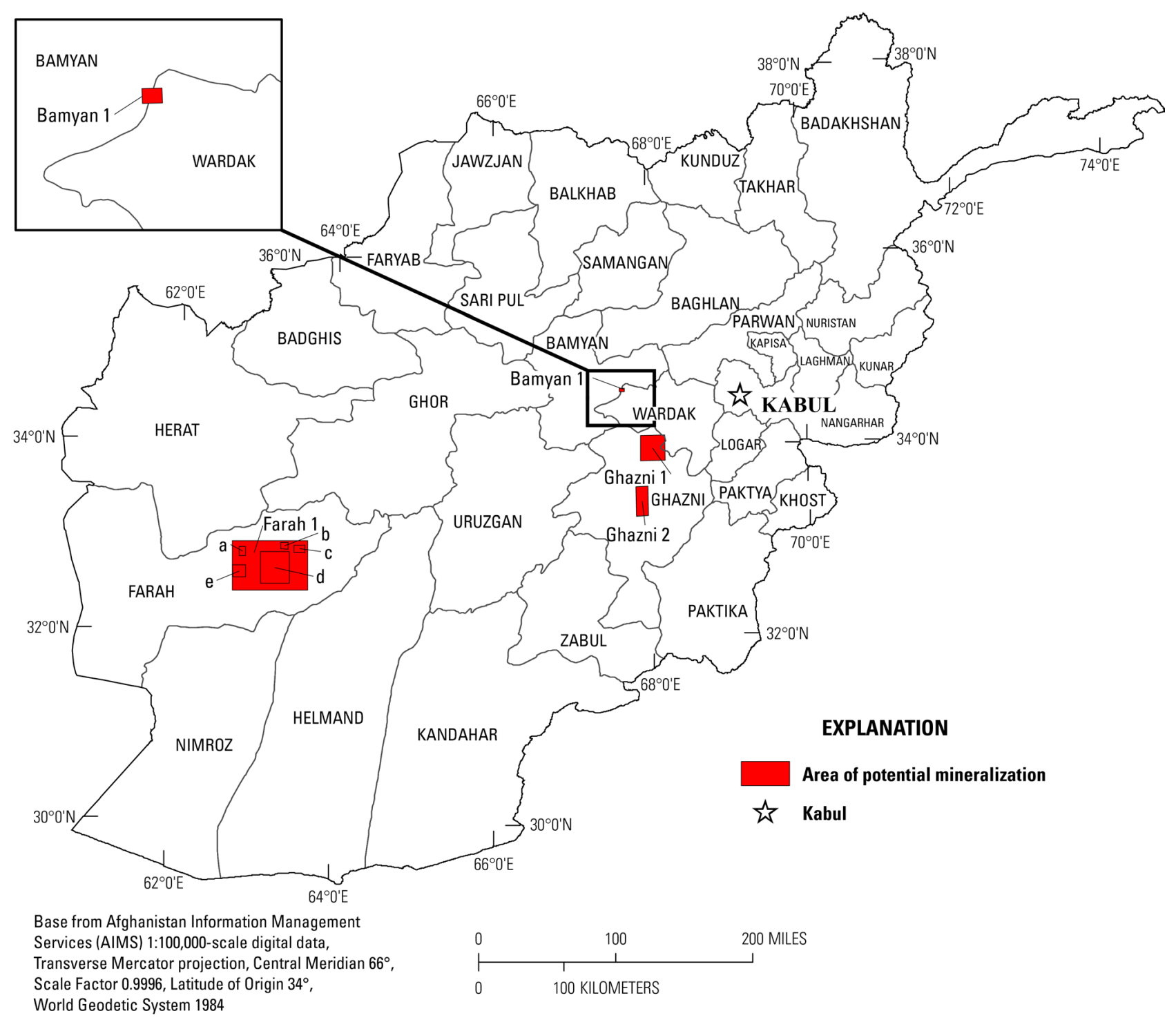

Figure 1. Location map showing the four areas of potential mineralization in Afghanistan discussed in the report: Bamyan 1, Farah 1, Ghazni 1, and Ghazni 2.

\section{Collection and Processing of Imaging Spectroscopy Data}

Imaging spectrometers measure the reflectance of visible and near-infrared light from the the Earth's surface in many narrow spectral channels, producing a reflectance spectrum for each image pixel. These reflectance spectra can be deconvolved to identify absorption features that arise from specific chemical transitions and molecular bonds; such information provides compositional information about surface materials. Imaging spectrometer data can only be used to characterize the surface materials and not subsurface composition or structure. Aspects of the subsurface can be inferred by the interpretation of the distribution of surface materials that can be detected using imaging spectroscopy data (Berger and others, 2003; Thompson and others, 2009) in the context of mineralizing processes. 
The imaging spectroscopy data for Afghanistan were collected by the HyMap ${ }^{\mathrm{TM}}$ sensor (Cocks and others, 1998) between August 22 and October 2, 2007, using the NASA WB-57 aircraft temporarily based at Kandahar Airfield. The data were collected from approximately 15 kilometer altitude in 28 flights. A total of 218 flight lines, covering a surface area of 438,012 square kilometers $\left(\mathrm{km}^{2}\right)$ were analyzed to produce the mineral maps (Kokaly and others, 2008). The HyMap ${ }^{\text {TM }}$ sensor measures 128 channels of reflected sunlight at wavelengths between 0.4 and $2.5 \mu \mathrm{m}$.

As part of the data analysis process, scaled radiance data were processed into atmospherically corrected reflectance data in a multistep process. In this process, the reflectance spectrum of each pixel was compared to the spectral features of reference standards in a spectral library of minerals using the Material Identification and Characterization Algorithm (MICA), a module of USGS Processing Routines in Interactive Data Language (IDL) for Spectroscopic Measurements software (Kokaly, 2011). For each pixel, MICA determined the reference material having the best matching spectrum. MICA analysis resulted in a "Not classified" determination for a pixel when comparisons with reference spectra produced no viable match. The material maps were pieced together to create thematic maps of surface mineral occurrences for approximately 70 percent of Afghanistan (King and others, 2011b; Kokaly and others, 2011).

Subsequent modifications to the mapping algorithm were used to produce updated material maps of the country (Kokaly and others, 2013). The surficial mineral maps for each of the four areas of potential mineralization are based on the revised thematic data (Kokaly and others, 2013).

\section{Mapping Results}

The HyMap ${ }^{\mathrm{TM}}$ data were used to produce two inclusive maps for each of the areas of potential mineralization: (1) Clays, carbonates, phyllosilicates, sulfates, altered minerals and other materials; and (2) iron-bearing minerals and other alteration materials. Depending on the observed mineral occurrences and geologic significance in ore formation processes, maps of surficial material subsets, such as "common alteration materials" have been prepared. Imaging spectroscopy data have proven valuable in identifying ore deposits on the basis of the extent and assemblages of alteration minerals associated with a specific deposit type and in detecting and mapping such alteration assemblages, variations in trace element mineral chemistry, and differences in the oxidation state of transition element-bearing minerals (Berger and others, 2003; King and others, 2011a; Peters and others, 2011).

Spectroscopic analysis of the HyMap ${ }^{\mathrm{TM}}$ data for the areas of potential mineralization identified a wide variety of minerals exposed at the surface. Although the occurrence of certain minerals may suggest that mineralization processes may have once operated in the area (Thompson, 2009), caution must be applied because many of the minerals identified by the analysis of the hyperspectral data are also common weathering products of rock-forming minerals.

\section{Site Selection}

Four areas of potential mineralization (Bamyan 1, Farah 1, Ghazni 1, and Ghazni 2) have been identified and are discussed in this report. These areas were selected on the occurrence of selected mineral assemblages mapped using the HyMap ${ }^{\mathrm{TM}}$ data; the initial filtering required the presence of one or more of the minerals included in the "common alteration mineral assemblage" map products. The spectroscopic common alteration mineral assemblage includes the following minerals and mineral groups: kaolinite, jarosite, hydrated silica, chlorite, epidote, iron-bearing carbonate, buddingtonite, dickite, and alunite (King and others, 2011a; Peters and others, 2011). Additional criteria and material reviewed as input data included existing geologic maps, Landsat Thematic Mapper (TM) data, and published literature (Abdullah and Chmyriov, 1977; Abdullah and others, 1977; Doebrich and Wahl, 
2006; Davis, 2007; Peters and others, 2007). Approximately 30 locations were initially identified; however, following analysis of the input data the four areas discussed here are credible sites for future mineral resource development.

Supporting mineralogical and structural interpretations of the areas are based on existing geologic reports and maps (Abdullah and Chimyrov, 1977; Abdullah and others, 1977; Tapponnier and others, 1981; Doebrich and Wahl, 2006; Davis, 2007; Peters and others, 2007) and summaries of the tectonic and structural history of Afghanistan (Wheeler and others, 2005).

The use of hyperspectral data for resource evaluations has provided a tool for making geologically sound decisions, precluding grand scale speculation, in a region lacking modern interpretative data products. Additional information from field-sampling, mapping, and supporting geochemical analysis are necessary to fully confirm the specific deposit types in the four areas.

Following are detailed descriptions of the areas identified during the analysis of the HyMap ${ }^{\mathrm{TM}}$ imaging spectroscopy data as being permissive for mineral resource development.

\section{Bamyan 1 Area of Potential Mineralization}

The Bamyan 1 area of hydrothermal alteration is located in Tertiary rocks towards the eastern end of the middle Afghanistan Farah Rud tectonic zone between the Herat fault zone on the north and the Helmand fault zone on the south (figs. 2 and 3). This study infers a mineral deposit type with the potential for undiscovered resources of copper and gold. 


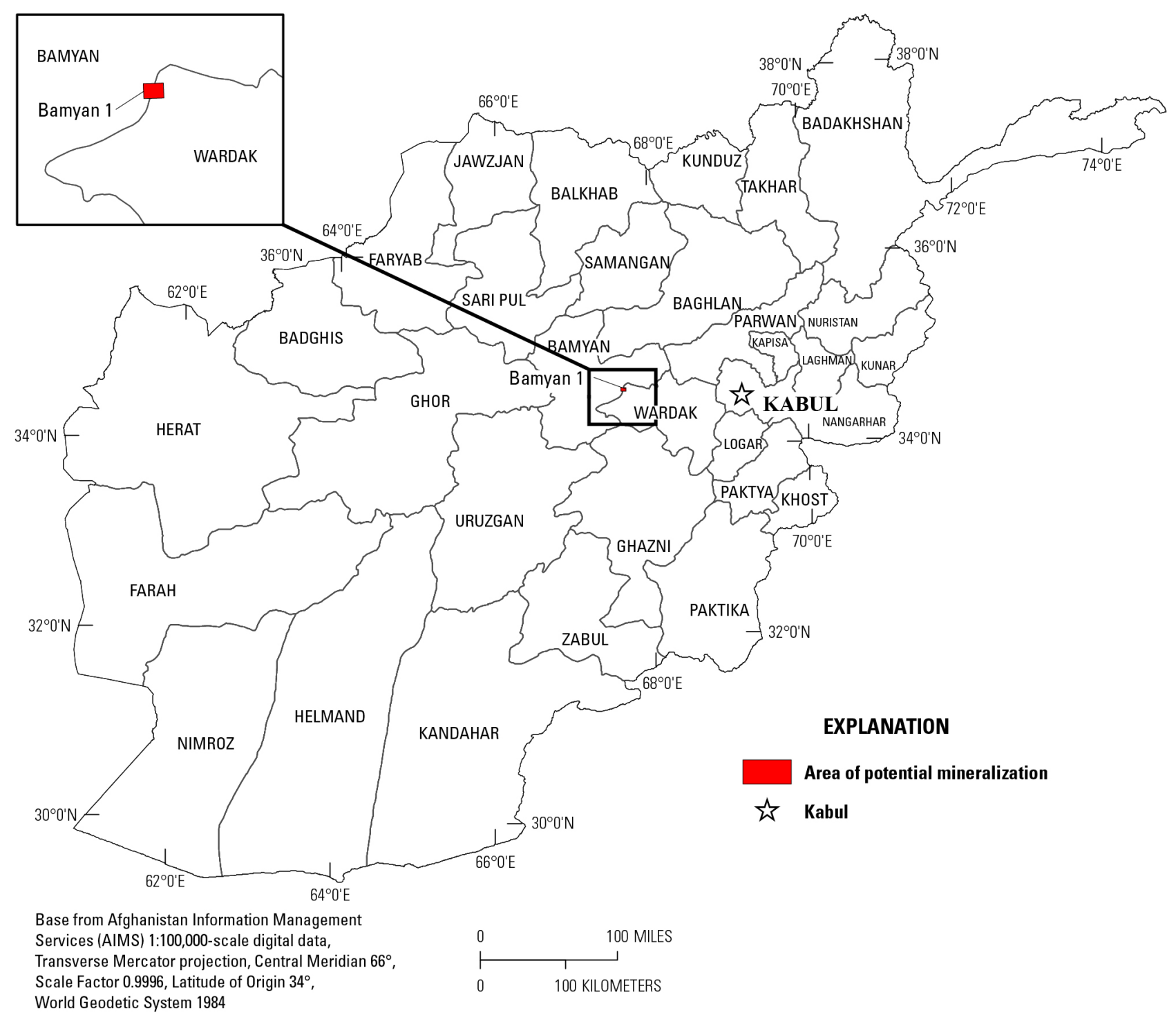

Figure 2. Location of the Bamyan 1 area in Afghanistan. 


\section{EXPLANATION}

Stratified rocks

Middle Quaternary

Pliocene. Undifferentiated

Miocene. Undifferentiated

Oligocene

Eocene-Oligocene

Late Cretaceous. Undifferentiated

Maastrichtian-Paleocene

Upper Aptian stage-Albian

Berriasian-Valanginian

Late Jurassic-Early Cretaceous

Early Jurassic-Middle Jurassic

Middle Triassic

Early Triassic

Late Permian

Early Permian. Undifferentiated

Carboniferous-Early Permian

Mississippian. Undifferentiated

Late Devonian-Missisippian

Late Proterozoic. Early part

Middle Proterozoic. Late part

Middle Proterozoic. Early part

Early Proterozoic

Intrusive rocks

\section{Oligocene}

Late Cretaceous-Paleocene

Early Cretaceous

Late Triassic

Proterozoic

\section{Bamyan 1}

Lithologic contact

- Faults

- Thermal springs (Abdullah and Chmyriov, 1977)

- Province center

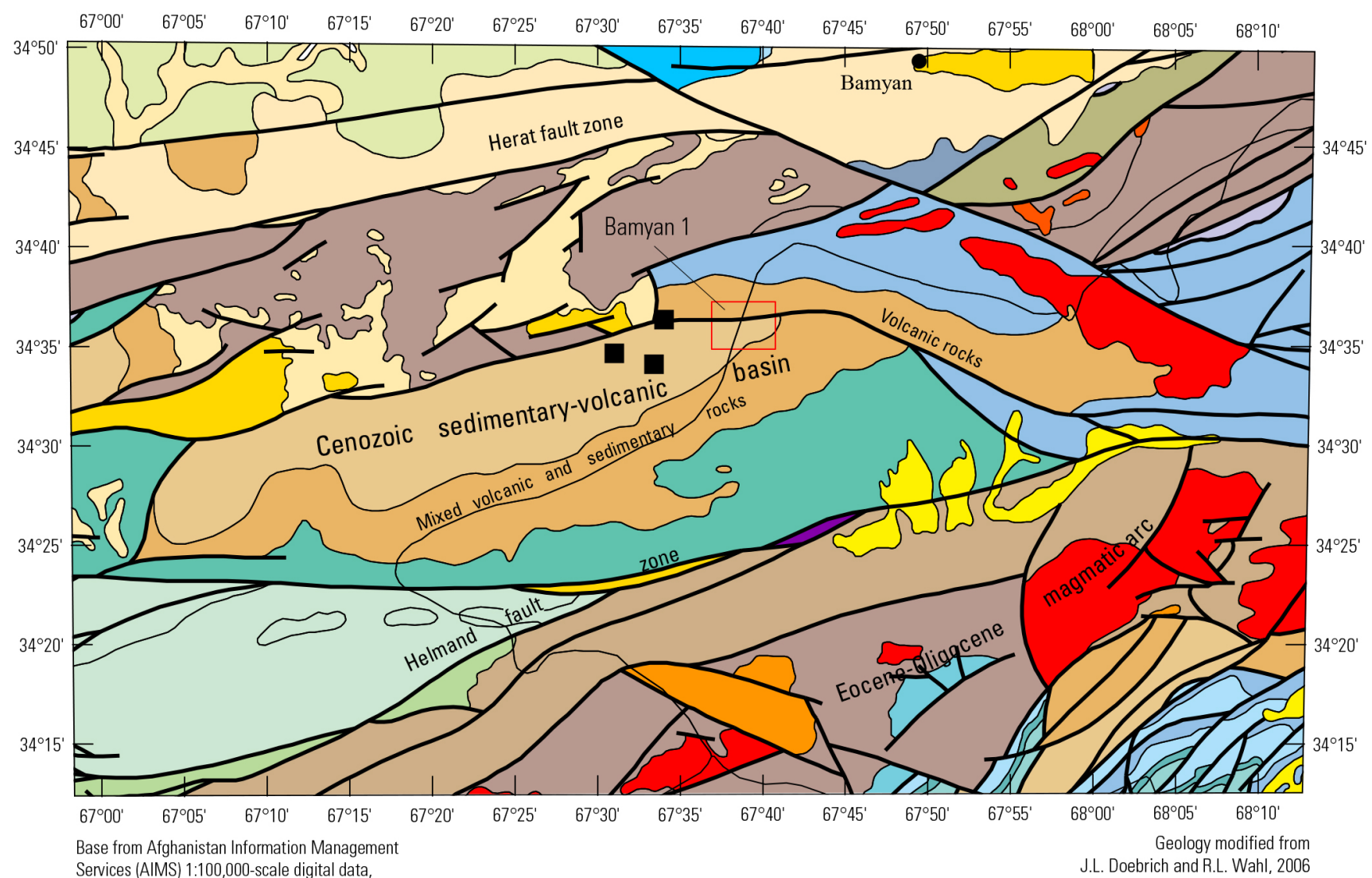

Services (AIMS) 1:100,000-scale digital data,

Transverse Mercator projection, Central Meridian $66^{\circ}$ World Geodetic System 1984

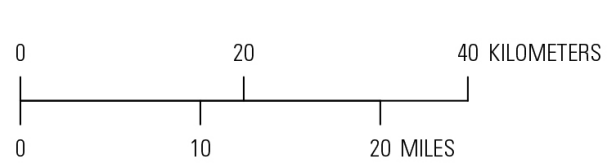

J.L. Doebrich and R.L. Wahl, 2006

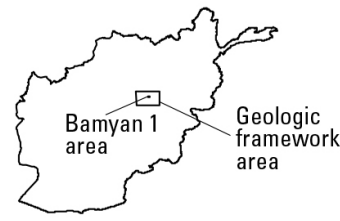

AFGHANISTAN LOCATION MAP

Figure 3. Geologic framework map of the Bamyan area including the Bamyan 1 area in Afghanistan (Abdullah and Chmyriov, 1977; Abdullah and others, 1977; Doebrich and Wahl, 2006). Map includes locations of thermal springs (Abdullah and others, 1977). 
Two potential hydrothermal alteration assemblages are evident in the hyperspectral data. The most aerially extensive alteration assemblage consists of silica, kaolinite, alunite, and pyrophyllite; more restricted, but still prominent is the assemblage silica and buddingtonite. These alteration assemblages are consistent with epithermal-type deposits of the quartz-alunite-kaolinite copper-gold (for example, Berger, 1986) and quartz-adularia gold-silver (for example, Mosier and others, 1985) varieties. Thus, this area has the potential for resources of gold, copper, arsenic, antimony, and mercury, and warrants further study and evaluation.

\section{Previous Work}

There is scant geologic information available regarding the area of alteration; the most detailed geologic and mineral-resource information are provided by reconnaissance field work subsequently compiled at a scale of 1:500,000 by Abdullah and Chmyriov (1977), Abdullah and others (1977), and Doebrich and Wahl (2006) (fig. 3).

\section{Geology}

The Bamyan 1 area is located in east-central Afghanistan along a generally east-northeast, southdipping fault zone at approximately $34^{\circ} 36^{\prime} 1 " \mathrm{~N}$ latitude and $67^{\circ} 38^{\prime} 45^{\prime \prime} \mathrm{E}$ longitude, about $25-30 \mathrm{~km}$ southwest of Bamyan (figs. 3 and 4). The study area is bisected by an unnamed, east-west trending fault and the south side of the study area is mapped as undivided Oligocene siliciclastic and carbonate sedimentary rocks and mafic to siliceous volcanics which have been hydrothermally altered (Abdullah and Chmyriov, 1977; Abdullah and others, 1977; and Doebrich and Wahl, 2006). Rocks in the north face of the east-west transversing fault are Eocene to Oligocene volcanic and sedimentary units that are reported to include andesitic basalt, basalt, trachyte, rhyolite, ash-flow tuffs, conglomerate, sandstone, siltstone, and limestone (fig. 4). The predominant sedimentary rock types in the area are sandstone, siltstone, clay, conglomerate, limestone, and marl (Abdullah and Chmyriov, 1977; Abdullah and others, 1977; and Doebrich and Wahl, 2006). 


\section{EXPLANATION}

Stratified Rocks

Oligocene

Eocene-Oligocene

Lithologic contact

Faults

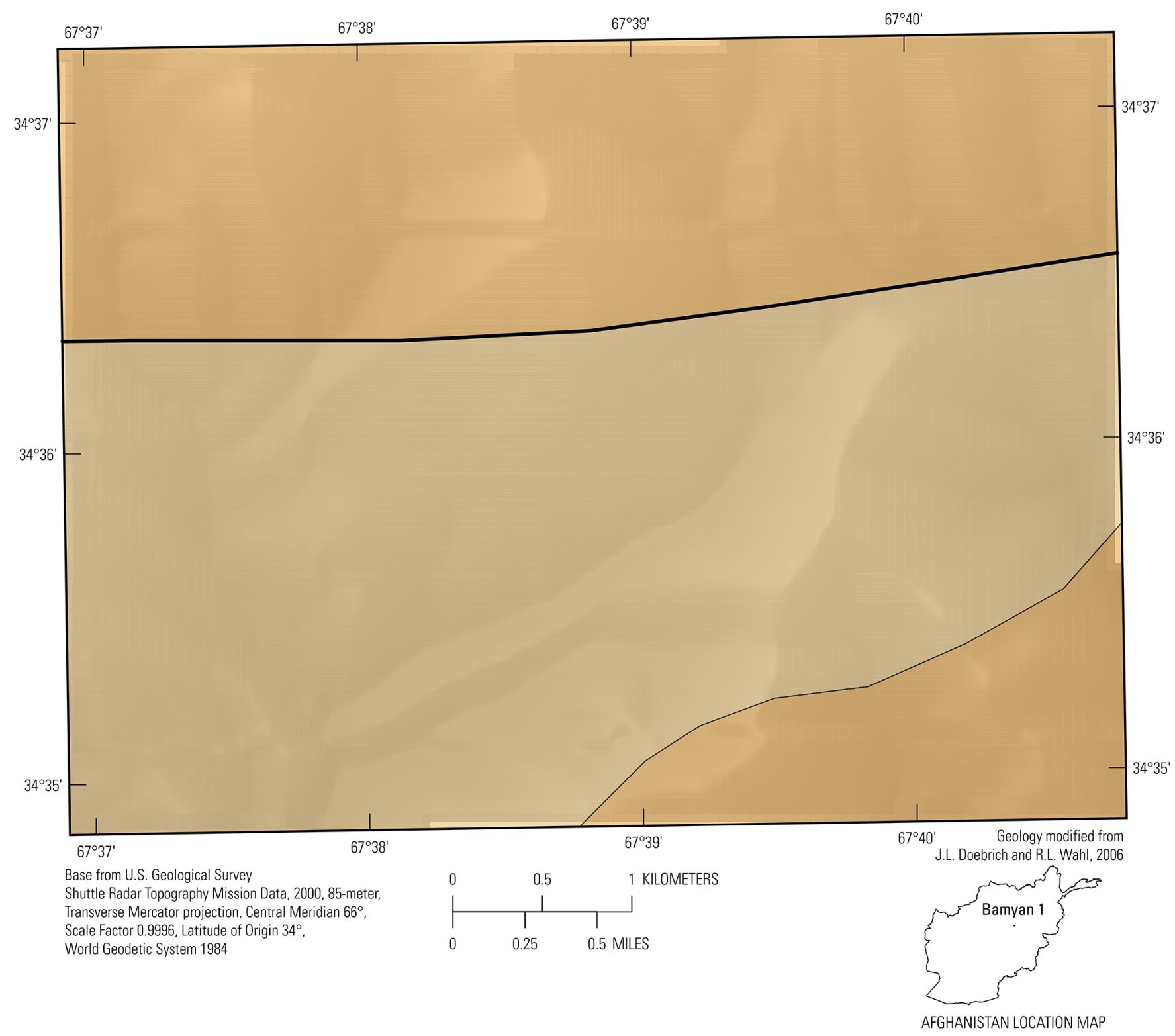

Figure 4. Geologic map of the Bamyan 1 area in Afghanistan shown as a red box on Figure 3 (Abdullah and Chmyriov, 1977; Abdullah and others, 1977; Doebrich and Wahl, 2006). 
The Cenozoic host rocks within the study area likely formed in a structural basin on a basement of late Paleozoic to middle Mesozoic rocks that lie unconformably on Mesoproterozoic to Neoproterozoic rocks with oceanic affinities (Abdullah and Chmyriov, 1977; Abdullah and others, 1977; Doebrich and Wahl, 2006). The Cenozoic basin and the underlying basement are within a tectonic unit referred to here as the Farah Rud block (Montenat, 2009) bounded by two major regional fault zones, the Herat fault zone to the north and the Helmand to the south, formed during two Jurassic accretion events (Tapponnier and others, 1981). The Farah Rud block has been internally deformed post-Mesozoic by faults that link into the bounding regional fault zones. Thus, the history of deformation on the regional faults likely affected the timing and nature of deformation in the zone of mapped alteration.

The Herat fault zone is located a few kilometers north of the Bamyan 1 area of potential mineralization (fig. 3) represented by a broad zone of right-lateral, strike-slip faulting with a length on the order of 1,100 km (Abdullah and Chmyriov, 1977; Abdullah and others, 1977; Doebrich and Wahl, 2006). It was most active during the late Eocene to Miocene (Wheeler and others, 2005), although faceted streambank sediments in the vicinity of Bamyan imply some present-day seismicity along the Herat fault zone (Tapponnier and others, 1981).

The Herat and Helmand fault zones represent Jurassic suture zones. The Helmand fault zone is younger and converges towards the Herat zone to the northeast (fig. 3). According to Wheeler and others (2005), the Herat and Helmand collision zones were reactivated in strike-slip transtension during the Oligocene and Miocene coincident with sedimentary basin development and volcanic activity in the area of alteration. East of the study area, the localizing fault curves to the southeast and links into the northeast-striking Helmand fault zone (fig. 3). Thus, deformation in the study area is coupled to the two regional fault zones.

To the east, south, and southwest of the study area, there are small Oligocene intrusive complexes that make up a magmatic arc built to a large extent across the Helmand fault zone on a Precambrian basement of continental affinity, a marked contrast with the oceanic basement beneath the study area (Abdullah and Chmyriov, 1977; Doebrich and Wahl, 2006). If the Tertiary volcanic and sedimentary rocks are coeval with the Oligocene intrusions and were deposited in something akin to a pull-apart basin, then the zone of alteration is located in a back-arc region that underwent greater extension than along the main volcanic front. Further, the basin has been dismembered to a greater extent than the main arc trend, likely a consequence of post-Oligocene deformation along the Herat fault zone.

The Herat and Helmand fault zones are not seismically active at present, but merge to the east into the currently active Chaman fault zone, a consequence of the Cenozoic collision of India and Asia (Wheeler and others, 2005). It is likely that some Miocene and younger deformation has been ongoing within the northeastern Farah Rud block. The importance of the regional tectonics to the study area is that faults between the Herat and Helmand fault zones were active concurrent with deformation along the boundary zones. Thus, mineralization took place in a zone of, and during a period of, strike-slip transtensional deformation that changed in character with time as the regional tectonics evolved. How such change affected the hydrothermal system that formed the study area is unknown, but as discussed below, syn-deformation mineralization is an important attribute of the mineral-deposit type inferred from the mineral assemblage in the zone of alteration.

\section{Mineralization}

The alunite/pyrophyllite alteration and association with earlier volcanic activity are consistent with the copper-gold deposit model and attendant advanced argillic alteration (Berger, 1986; Henley and 
Berger, 2011). In this model, high-temperature gases released from an underlying magma reservoir rise, expand and lose sufficient heat to condense to a two-phase mixture of acidic fluid and vapor. The acidic fluid alters the surrounding rock to form small to large volumes of dense, fine-grained silica with associated alunite, kaolinite, pyrophyllite, diaspore and other aluminosilicate minerals. If structural conditions are appropriate (Berger and Henley, 2011), localized refracturing of the embrittled, insulating silica-alunite rocks can result in the deposition of sulfide, sulfosalt, telluride, and native metals from the magmatic vapor. In the peripheral parts of the magmatic-vapor plume, condensation into local ground waters may create an advecting, near-neutral $\mathrm{pH}$ geothermal system. Future sampling and detailed mapping may better define the peripheral part of the alteration system, which is characteristically composed of silica, potassium feldspar, white mica, chlorite, and epidote.

Continuing tectonic activity during the course of hydrothermal activity can lead to repetitive refracturing. The antecedent silica-alunite rock acts as an embrittled insulator. When it is refractured, it allows the magmatic gas flow to retain its heat content, which, in turn, leads to the deposition of sulfide, sulfosalt, and sulfate minerals in the refractured masses. Therein lies the importance of synmineralization tectonic and structural change in the area of alteration to ore formation in silica-alunite beneath the surface and the hypothetical formation of a copper-gold deposit.

\section{Imaging Spectroscopy Data}

Figure 5 depicts the distribution of the iron-bearing minerals and other materials in the Bamyan 1 area. Hematitic and goethitic minerals, along with dry and green vegetation, are the most abundant materials mapped using the HyMap ${ }^{\mathrm{TM}}$ data in the Bamyan 1 area. In the southern part of the study area, the hematitic minerals are mapped primarily in Eocene-Oligocene stratified sedimentary rocks (sandstone, siltstone, and claystones with acid and mafic rocks). On the north side of the east-west trending cross-cutting fault that dissects the study area, the Eocene-Oligocene rocks are reported to consist of stratified acid volcanic rocks and sandstone, siltstone, and limestone (fig. 4) (Abdullah and Chmyriov, 1977; Abdullah and others, 1977; and Doebrich and Wahl, 2006). The surficial minerals mapped on the north side of the fault include $\mathrm{Fe}^{2+} \mathrm{Fe}^{3+}$ group minerals along with lesser amounts of $\mathrm{Fe}^{3+}$ group minerals, goethite, and hematite. The $\mathrm{Fe}^{3+}$ group minerals, along with minor amounts of maghemite, show preferential distribution along the east-west fault trace dissecting the study area. Adjacent to the cross-cutting fault in the Eocene-Oligocene rocks, a loosely defined area of alteration assemblage minerals including $\mathrm{Fe}^{3+}, \mathrm{Fe}^{2+} \mathrm{Fe}^{3+}$ group minerals, goethites, Fe-hydroxide, epidote and hematite is mapped using the HyMap ${ }^{\mathrm{TM}}$ data. The black areas in figure 5 correspond to areas where no minerals were mapped because of either their lack of absorption features in the visible/near-infrared portion of the electromagnetic spectrum or lack of spectral standard used for comparison in the mapping algorithm.

Mineral distribution patterns in the carbonates, phyllosilicates, sulfates, altered minerals, and other materials map (fig. 6) show that alunite group minerals (alunite and alunite and kaolinite), kaolinite group minerals, and lesser amounts of buddingtonite and pyrophyllite form a well-defined circular alteration area that is approximately $4.5 \times 2.0 \mathrm{~km}$. The alunite group minerals form the central core of the feature ringed by kaolinite group minerals. Pyrophyllite is present on the western side associated with the alunite group minerals and kaolinite. Buddingtonite is mapped along a linear zone, possibly defining an unmapped fault that crosses the alteration zone. The formation of the buddingtonite zone may or may not be related to the hydrothermal activity that produced the alunite/kaolinite alteration (figs. 7 and 8). 
EXPLANATION

Mineral class (pixel count)

Not classified $(18,129)$

Hematite, nanocrystalline $(11,330)$

Iron hydroxide (293)

Goethite, fine-grained (202)

Goethite, medium-grained (74)

Goethite, coarse-grained (47)

Fe2+ type 2 (37)

Fe3+ type $1(1,134)$

Fe3+ type 2 (70)

Fe2+Fe3+ type $1(2,246)$

$\mathrm{Fe} 2+\mathrm{Fe} 3+$ type 2 (331)

Epidote (259)

Maghemite (25)

Green vegetation $(4,615)$

Dry vegetation $(10,217)$

Snow and ice (11)

Faults

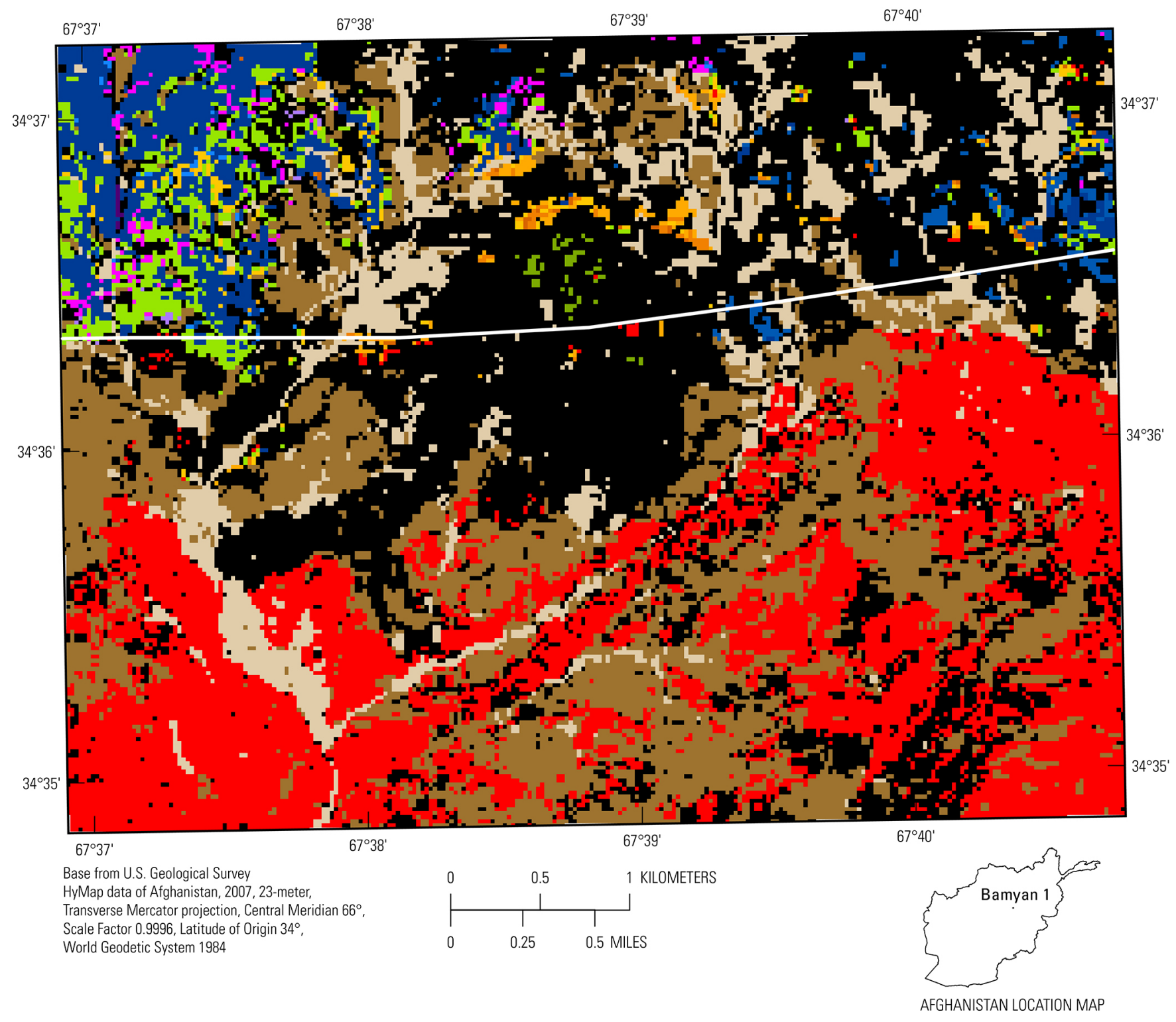

Figure 5. Map of iron-bearing minerals and other materials derived from HyMap ${ }^{\mathrm{TM}}$ data in the Bamyan 1 area in Afghanistan (King and others, 2011b; Kokaly and others, 2013). 


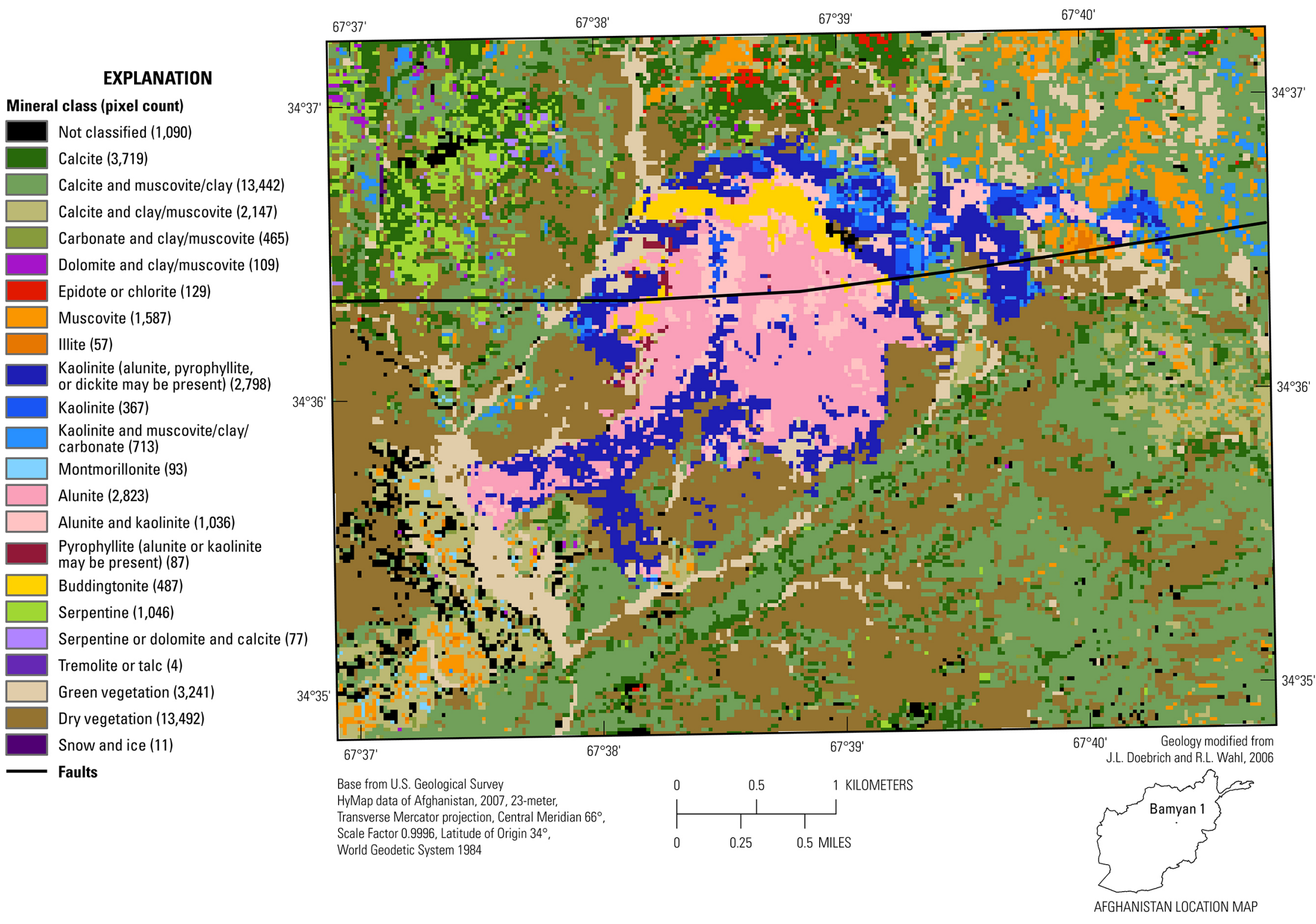

Figure 6. Map of carbonates, phyllosilicates, sulfates, altered minerals, and other materials derived from HyMap ${ }^{\text {TM }}$ data in the Bamyan 1 area in Afghanistan (Kokaly and others, 2011, 2013). 


\section{EXPLANATION}

Class Name (pixel count)

Epidote or chlorite (129)

Kaolinite (alunite, pyrophyllite, or

dickite may be present) $(2,798)$

Kaolinite (367)

Kaolinite and muscovite/clay/

carbonate (713)

Alunite $(2,823)$

Alunite and kaolinite $(1,036)$

Pyrophyllite (alunite or kaolinite

may be present) (87)

Buddingtonite (487)

Lithologic contact

Faults

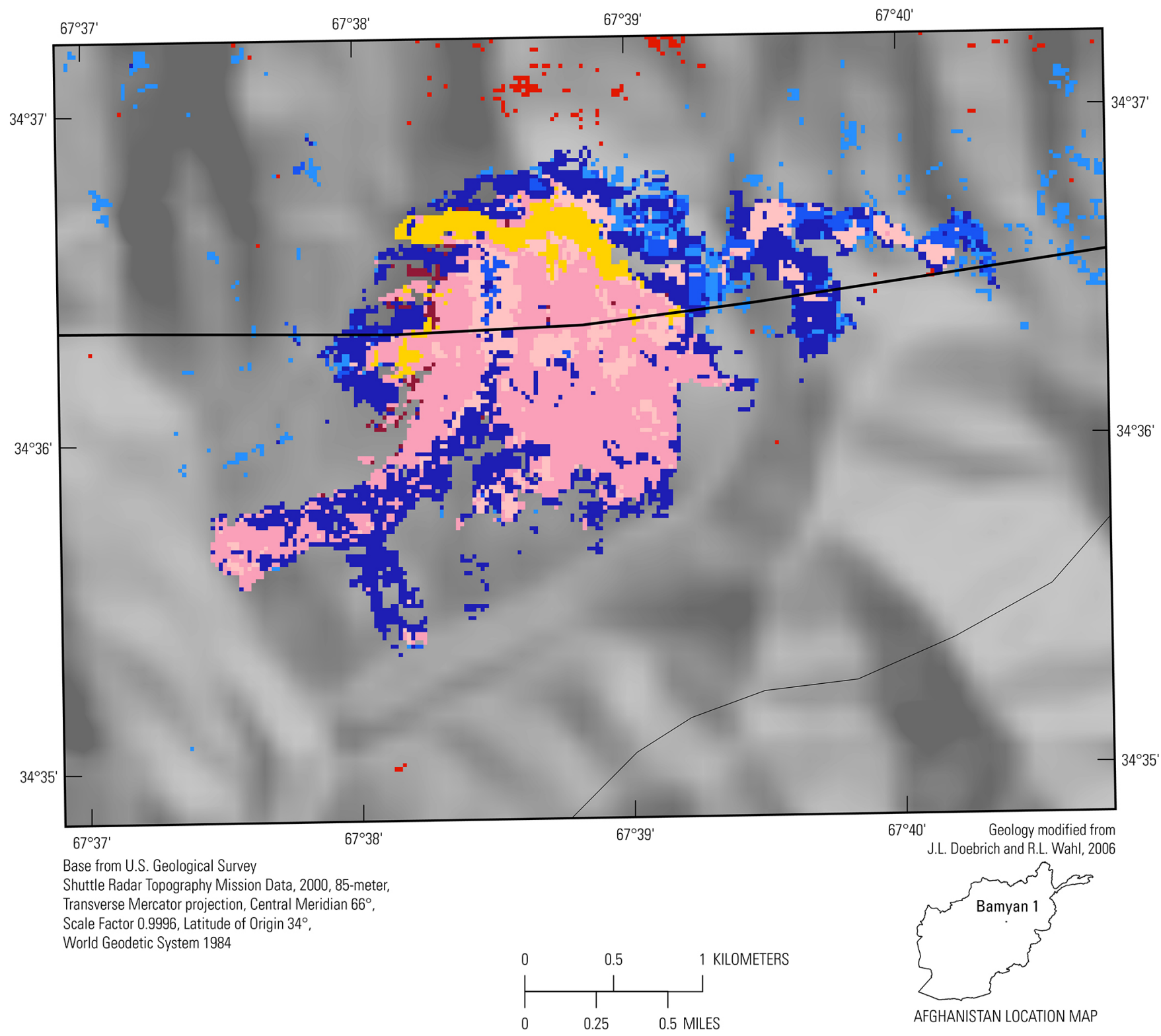

Figure 7. Map showing common alteration minerals derived from HyMap ${ }^{\text {TM }}$ data in the Bamyan 1 area in Afghanistan (Kokaly and others, 2011, 2013). The detection of common alteration minerals is suggestive of possible past mineralization processes. 


\section{EXPLANATION}

Class Name (pixel count)

Epidote or chlorite (129)

Kaolinite (alunite, pyrophyllite, or

dickite may be present) $(2,798)$

Kaolinite (367)

Kaolinite and muscovite/clay/carbonate (713)

Alunite $(2,823)$

Alunite and kaolinite $(1,036)$

Pyrophyllite (alunite or kaolinite

may be present) (87)

Buddingtonite (487)

¿3 Lithologic contact

Faults

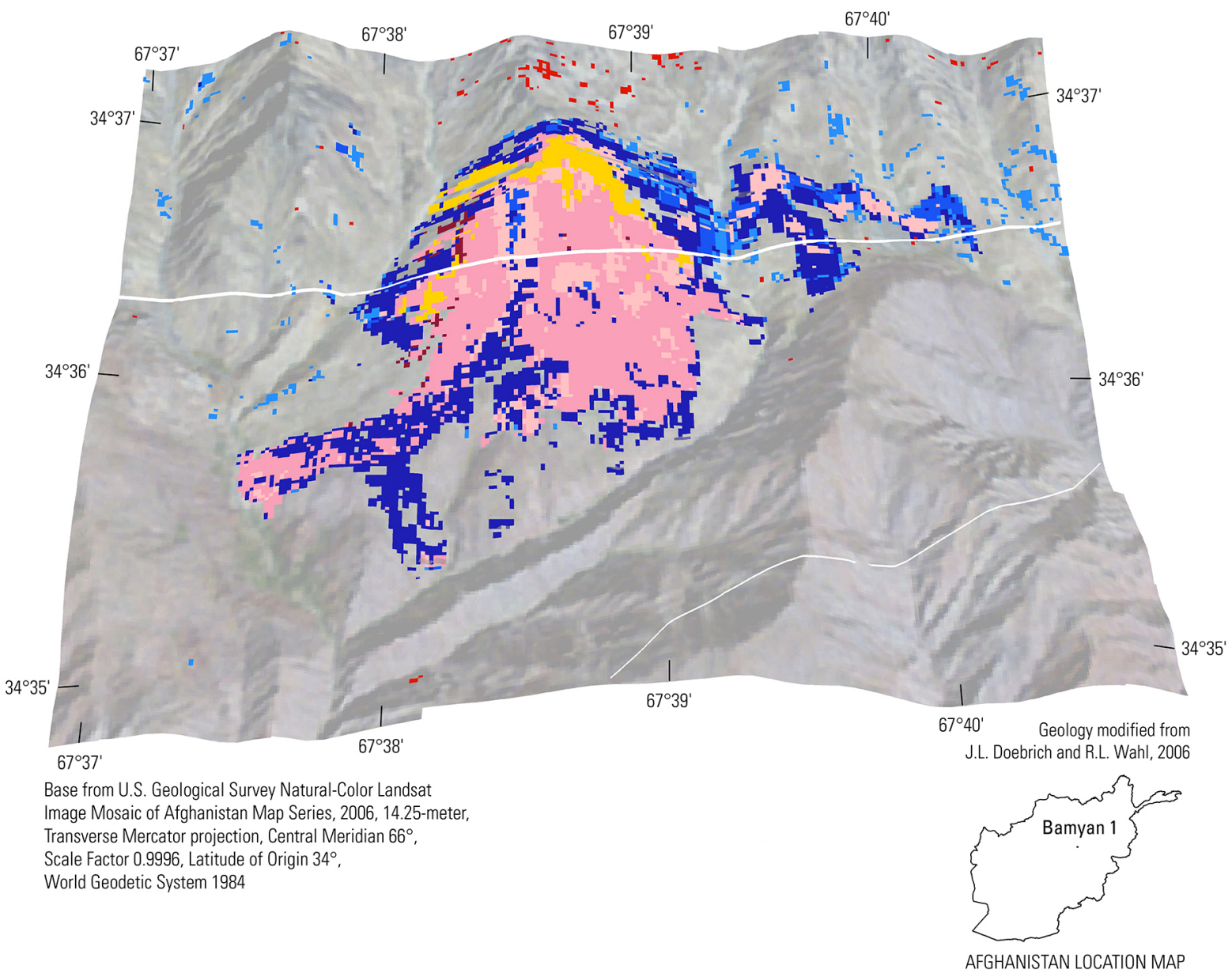

Figure 8. A three-dimensional image showing common alteration minerals derived from HyMap ${ }^{\mathrm{TM}}$ data overlain on a digital elevation model (Davis, 2007) in the Bamyan 1 area in Afghanistan (Kokaly and others, 2011, 2013). 
Approximately $1 \mathrm{~km}$ west of the dominant central feature, adjacent to the cross-cutting fault in the Eocene-Oligocene rocks, an additional, less defined, alteration assemblage of serpentine minerals, kaolinite and kaolinite and muscovite mixtures, dolomite and epidote and muscovite is mapped (fig 6). A well-defined area of epidote is mapped in the Eocene-Oligocene rocks east of the central alteration zone (fig 7). The area surrounding the alunite/pyrophyllite topographic high (Chirico and Barrios, 2005) is primarily mapped as mixtures of calcite and mixed calcite and muscovite, muscovite, with minor amounts of epidote along with green and dry vegetation. Small isolated groupings of serpentine, muscovite, and kaolinite group minerals occur intermittently with snow at higher elevations.

Based on our previous work (Berger and others, 2003) and the work of others (Thompson and others, 2009), the assemblage of alteration minerals is readily identified using spectroscopic mapping techniques and is clearly indicative of advanced argillic alteration. This provides strong evidence of mineralization and support for Bamyan 1 being an exploration target (fig. 8).

\section{Summary of Potential Mineralization}

The study area is consistent with the silica-alunite-kaolinite and pyrophyllite type of copper-gold deposit model. However, verification of ore bodies can be determined only through on-the-ground field studies and geochemical sampling.

\section{Farah 1 Area of Potential Mineralization}

The Farah 1 area is located northeast of Farah (fig. 9). Eocene to Oligocene volcanics and volcaniclastics and related intrusive rocks outcrop toward the western end of the middle Afghanistan Farah Rud tectonic zone between the Herat fault zone on the north and the Helmand fault zone on the south. Much of the volcanic field is fault bounded, although in part unconformable on Mesozoic sedimentary and volcanic rocks. 


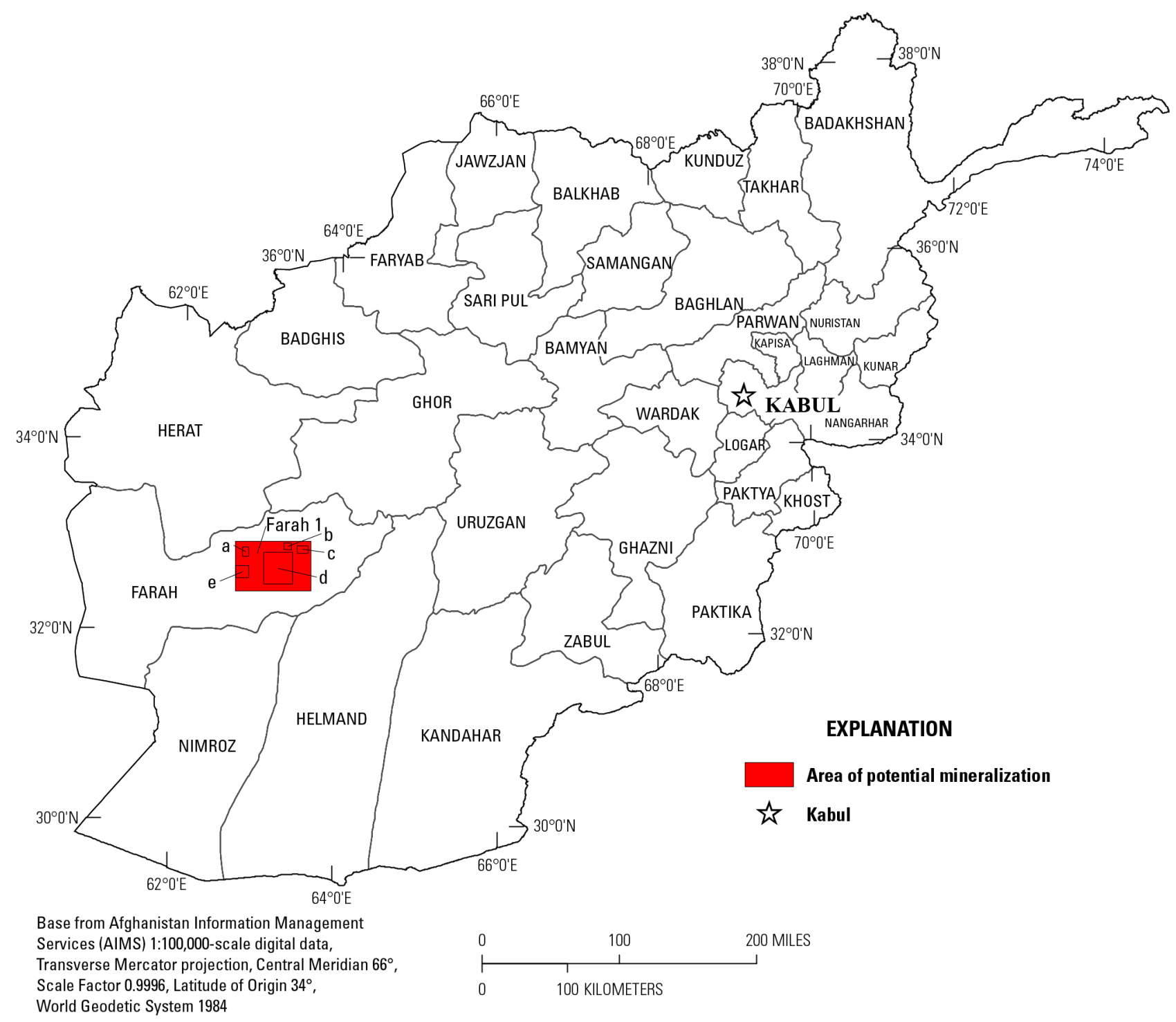

Figure 9. Location of the Farah 1 area with five subareas (a, b, c, d, and e) in Afghanistan.

Five subareas with discrete zones of hydrothermal alteration are evident in the hyperspectral data. The predominant alteration minerals in these zones are white mica, chlorite, epidote, and kaolinite. This assemblage is consistent with mineral-deposit models of polymetallic-type vein deposits that elsewhere in the study area are known to contain copper, zinc, lead, silver, and gold (Abdullah and others, 1977; Peters and others, 2007). Spectral indications of buddingtonite (ammonium feldspar) suggest that $\mathrm{K}$-feldspar is part of the alteration assemblage. The proximity of polymetallic quartzcarbonate veins provides additional support to the conclusion that this region has the potential to contain undiscovered resources of base and precious metals, and warrants further study and evaluation. 


\section{Previous Work}

There is scant geologic information available regarding the areas of alteration; the most detailed geologic and mineral-resource information is provided by Wittekindt and Weippert (1973), Abdullah and Chmyriov (1977), Abdullah and others (1977), Doebrich and Wahl (2006), and Peters and others (2007, 2011).

\section{Geology}

The Farah 1 area is located in west-central Afghanistan on the north margin of a broad northwest-striking fault zone including the Farah Rud fault zone that separates the study area from the Helmand fault zone to the south and east (Abdullah and Chymriov, 1977; Wheeler and others, 2005; Doebrich and Wahl, 2006; Ruleman and others, 2007, fig. 13, p. 30) (fig. 10). The Eocene-Oligocene Farah 1 volcanic field measures approximately $90 \mathrm{~km}$ wide and $60 \mathrm{~km}$ from north to south (fig. 10). The volcanic field consists predominantly of andesitic and dacitic volcanic rocks, although minor basalts and rhyolites are present (Abdullah and Chmyriov, 1977; Abdullah and others, 1977; Doebrich and Wahl, 2006). Eocene-Oligocene granodiorite to granite intrusions are exposed in the field area (fig. 10), primarily in its southern half (Abdullah and Chmyriov, 1977). 


\section{EXPLANATION}

Stratified rocks

Latest Quaternary

Late Quaternary

Middle Quaternary

Oligocene

Eocene-Oligocene

Upper Aptian stage-Albian

Barremian-Aptian

Valanginian-Hauterivian

Berriasian-Valanginian

Late Jurassic-Early Cretaceous

Intrusive rocks

Oligocene

Eocene-Oligocene

$\left\llcorner \_\right\lrcorner$Subarea boundary

$\because \because$ Volcanic field

Lithologic contact

- Faults

Population center

- District Center

\section{Non-fuel minerals}

$\triangle \quad$ volcanogenic massive sulfide

$\square \quad$ polymetallic vein

$B$ vein barite

unk $\mathrm{Hg}$

unk $\mathrm{Cu}$

Unnamed deposits are not labeled

负 Volcano

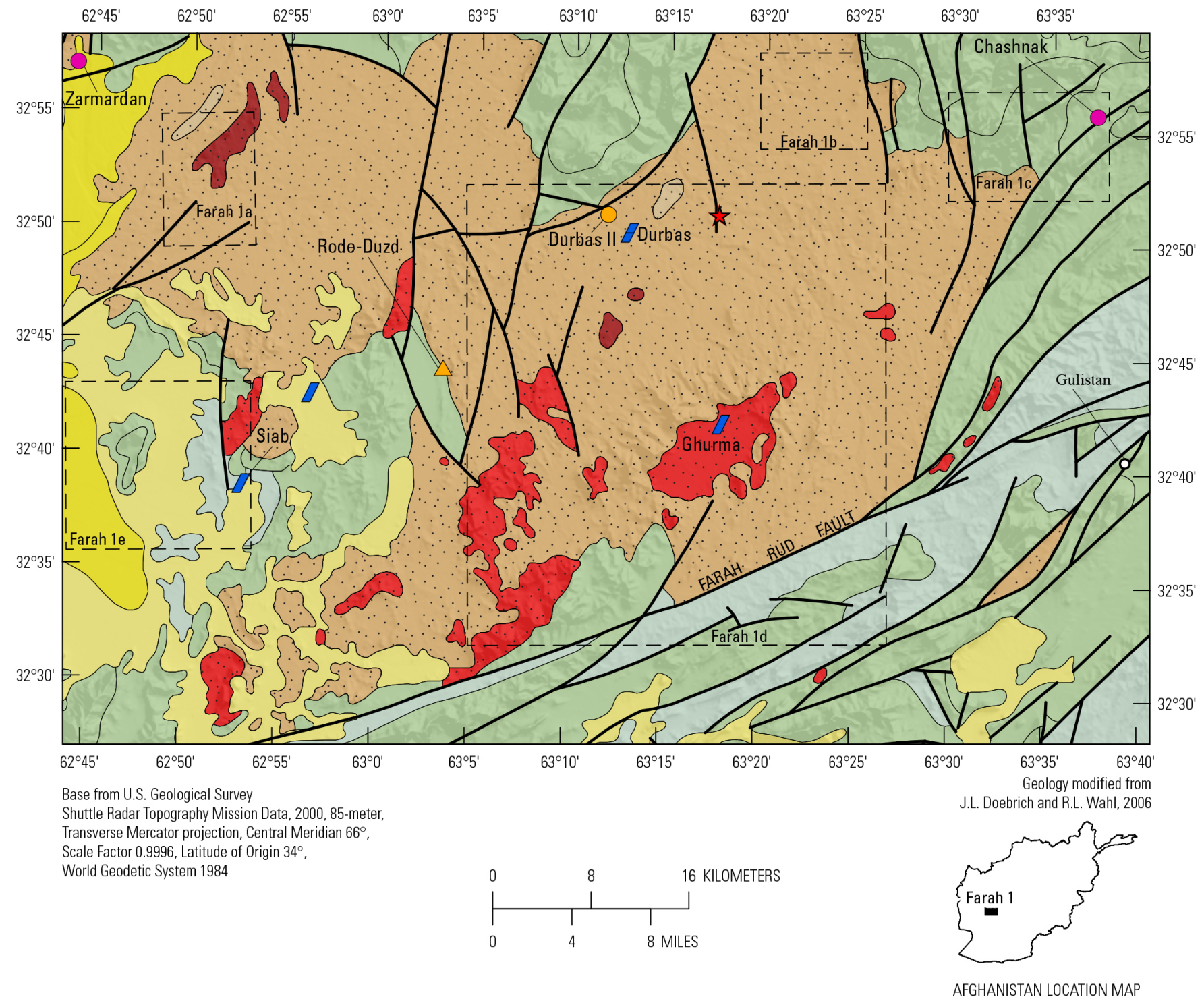

Figure 10. Geologic map of the Farah 1 area in Afghanistan (Abdullah and Chmyriov, 1977; Abdullah and others, 1977; Doebrich and Wahl, 2006). 
Lithologies and whole-rock chemistry suggest that the Farah 1 volcano-plutonic complex likely formed in a magmatic-arc environment on a basement of upper Mesozoic sedimentary rocks. The latter are a basinal sequence that surrounds the volcanic field and constitutes the predominant part of the Farah Rud tectonic block (Abdullah and Chmyriov, 1977). Some Jurassic rocks crop out in the north part of the tectonic block along the south side of the Herat fault zone. The Farah Rud block has been structurally deformed internally since the Mesozoic by faults that link into the bounding regional fault zones as discussed previously.

The Farah Rud block accreted to northern Afghanistan along the Herat fault/suture during the Jurassic, followed by a second accretion event along the Helmand fault zone during the later Jurassic (Tapponnier and others, 1981). Paleocene rocks are absent within the Farah Rud block, but Eocene sedimentary and volcanic rocks are widespread. Therefore, basin opening within the Farah Rud tectonic block likely occurred in the earliest Cretaceous shortly after suturing along the Helmand fault zone. Magmatic arc activity appears to have begun during the Eocene and peaked during the Oligocene (Abdullah and Chmyriov, 1977).

Although small Tertiary intrusives are widespread throughout the Farah Rud block, the clusters of small instrusives in the Farah 1 study area are uncommon elsewhere in the Farah-Rud tectonic block. It is probable that the Eocene-Oligocene intrusions and volcanic rocks in the study area are part of a more widespread Tertiary arc activity that included hydrothermal mineralization.

\section{Mineralization}

There are six base metal occurrences in the study area and two mercury $(\mathrm{Hg})$ occurrences (fig. 10). The mercury occurrences are similar to mercury deposits in the Mesozoic basin sedimentary rocks; although hosted in the Eocene-Oligocene volcanic rocks (Abdullah and Chmyriov, 1977). The Zarmardan Hg occurrence in the northwest corner of the Farah 1 study area is associated with quartz and carbonate gangue in sheared volcanic rock. Cinnabar is reported along with chalcopyrite, sphalerite, and galena (Abdullah and others, 1977). Intermediate subvolcanic intrusions also are reported in the area (Abdullah and Chmyriov, 1977; Abdullah and others, 1977; Doebrich and Wahl, 2006). The Chashnak Hg occurrence is in the northeast corner of the Farah 1 study area although geologic context is problematic. The geologic map shows that the occurrence is hosted in Cretaceous siliciclastic rocks, but the available deposit description states that the $\mathrm{Hg}$ mineralization is along brecciated zones in the Tertiary volcanic rocks (Abdullah and Chmyriov, 1977; Abdullah and others, 1977; Doebrich and Wahl, 2006). Cinnabar in a gangue of quartz and carbonate is reported along with chalcopyrite, sphalerite, and galena.

Six base metal occurrences in polymetallic veins are distributed through the study area (Abdullah and Chmyriov, 1977; Abdullah and others, 1977; Doebrich and Wahl, 2006) (fig. 10) and are described below. (1) The westernmost is Siab, in Lower Cretaceous volcanogenic and terrigenous rocks. Unspecified copper sulfide minerals are reported and with galena in quartz veins. (2) Unnamed copper and lead-bearing polymetallic quartz veins are reported in the west-central part of the study area northeast of Siab (fig. 10) hosted in Oligocene granite, below Quaternary cover. The occurrence is small, owing to the limited exposure of the granite in an area dominated by upper Quaternary sedimentary rocks. (3) To the northeast of this prospect is the Rode-Duzd volcanogenic massive sulfide. Copper oxide minerals, including malachite and azurite occur in Eocene-Oligocene andesite. (4) Durbas and (5) Durbas II are in the north-central part of the study area (fig. 10). Durbas is a barite vein that also contains copper, lead, and zinc minerals. Durbas II consists of Eocene-Oligocene dacite intrusive bodies that host mineralized lenses containing copper and zinc. Hydrothermal alteration consists of quartz, sericite, and chlorite. (6) The Ghurma occurrence is located in the east-central part of the study area 
within a granodiorite intrusion. Copper occurs in quartz veins with carbonate gangue, including siderite. The Ghurma mineralized zone exceeds $1 \mathrm{~km}$ in length and contains chalcopyrite and pyrite with minor amounts of lead and zinc. The veins occur at the intrusive contact with dacitic volcanic rocks.

\section{Imaging Spectroscopy Data}

Areas of hydrothermal alteration scattered throughout the Farah 1 volcano-plutonic field are readily delineated by HyMap ${ }^{\mathrm{TM}}$ hyperspectral data (King and others, 2011a, 2011b; Kokaly and others, 2011, 2013; Peters and others, 2011). Their distribution suggests local structural control (figs. 10 and 11). The prevalent alteration zones contain white mica, chlorite, epidote, and clay with widespread buddingtonite (fig. 12) and are located in Farah 1a, Farah 1b, and Farah 1d. In the northeast corner of the Farah 1 region (Farah 1c), there are zones of argillic alteration consisting of kaolinite, dickite, and possible alunite and pyrophyllite that straddle a fault zone that bounds the eastern margin of the volcanic field (fig. 12).

The carbonate minerals, predominantly calcite, are the most abundant mineral phases mapped using the HyMap ${ }^{\mathrm{TM}}$ data (fig. 11). The potassic alteration assemblage of muscovite, white mica group minerals (including mixtures of muscovite and other phyllosilicates) are widespread across the entire area. Similarly, montmorillonite and the relatively few kaolinite and kaolinite group minerals are also spatially dispersed over the area or occur in small, localized clusters. However, some mineral occurrences are associated with specific types of rocks. For example, the abundant carbonate group minerals (carbonate and clay mixtures) are commonly spatially coincident with underlying sedimentary rocks. Higher concentrations of muscovite, and associated illite, occur in the volcanic rocks (figs. 10 and 11). Likewise, chlorite and epidote most commonly occur in Eocene/Oligocene volcanic rocks. Buddingtonite and iron-bearing carbonate minerals are primarily mapped as small coherent clusters in Eocene/Oligocene volcanic rocks.

To provide more detailed explanation and mapping products, we have identified five subareas within the larger Farah 1 study area (Farah 1a-Farah 1e) that are discussed below.

\section{Farah 1a Subarea}

Farah 1a, located in the northwest part of the study area (fig. 12) is distinguished by abundant buddingtonite (fig. 13). The buddingtonite is spectrally mapped in Eocene/Oligocene rhyolitic/dacitic intrusive rocks. These intrusives are surrounded by Eocene/Oligocene stratified ignimbrites and tuffs rocks (fig. 14), consisting of basalt, andesitic basalt, andesite, dacite, trachyte compositions intercalated with conglomerate, sandstone, and siltstone (Abdullah and Chmyriov, 1977; Doebrich and Wahl, 2006) that are largely devoid of buddingtonite (fig. 13). In contrast, the HyMap ${ }^{\mathrm{TM}}$ data show the Eocene/Oligocene stratified volcaniclastic rocks contain alteration assemblages of muscovite and clay/muscovite and lesser amounts of montmorillonite, iron-carbonate minerals, and calcite. The HyMap $^{\mathrm{TM}}$ data show buddingtonite occurrences in the southwest parts of the subarea suggesting that the aerial extent of the Eocene/Oligocene intrusions may extend to the southwest (figs. 13 and 14). Epidote and chlorite are found in the contact zone adjacent to the proposed intrusive margin in the northeast and southwest corners of the subarea, whereas calcite is the dominant mineral in the Oligocene stratified rocks in the northwest part of the subarea.

The distribution of iron-bearing minerals indicates that $\mathrm{Fe}^{2+} \mathrm{Fe}^{3+}$ mineral groups, $\mathrm{Fe}^{2+}$ and $\mathrm{Fe}^{3+}$ and goethite mineral groups are the dominant iron-bearing mineral phases in the Farah 1a subarea (fig. 15), with lesser amounts of fine-grained hematite. Jarosite is abundant, along with small zones of coarse-grained hematite, in the areas coincident with buddingtonite (fig. 13). 


\section{EXPLANATION}

Class name (pixel count)

Not classified $(78,632)$

Calcite, abundant $(201,073)$

Calcite $(5,351,974)$

Calcite and muscovite/clay $(328,413)$

Calcite and clay/muscovite

$(2,437,754)$

Carbonate and clay/muscovit $(90,349)$

Carbonate, iron-bearing $(28,400)$

Dolomite (3,324)

Dolomite and clay/muscovite $(8,461)$

Epidote or chlorite $(270,275)$

Muscovite $(464,639)$

Illite $(251,500)$

Kaolinite (alunite, pyrophyllite, or

dickite may be present) $(1,466)$

Kaolinite (301)

Kaolinite and muscovite/clay/

carbonate $(19,946)$

Montmorillonite $(95,419)$

Alunite (8)

Alunite and kaolinite (4)

Pyrophyllite (alunite or kaolinite

may be present) (1)

Jarosite (58)

Buddingtonite $(4,864)$

Serpentine $(37,949)$

Serpentine, or dolomite and

calcite $(10,773)$

Tremolite or talc (35)

Hydrated silica (127)

Green vegetation $(27,194)$

Dry vegetation $(41,981)$

Water $(4,198)$

Wet soils (7)

Faults

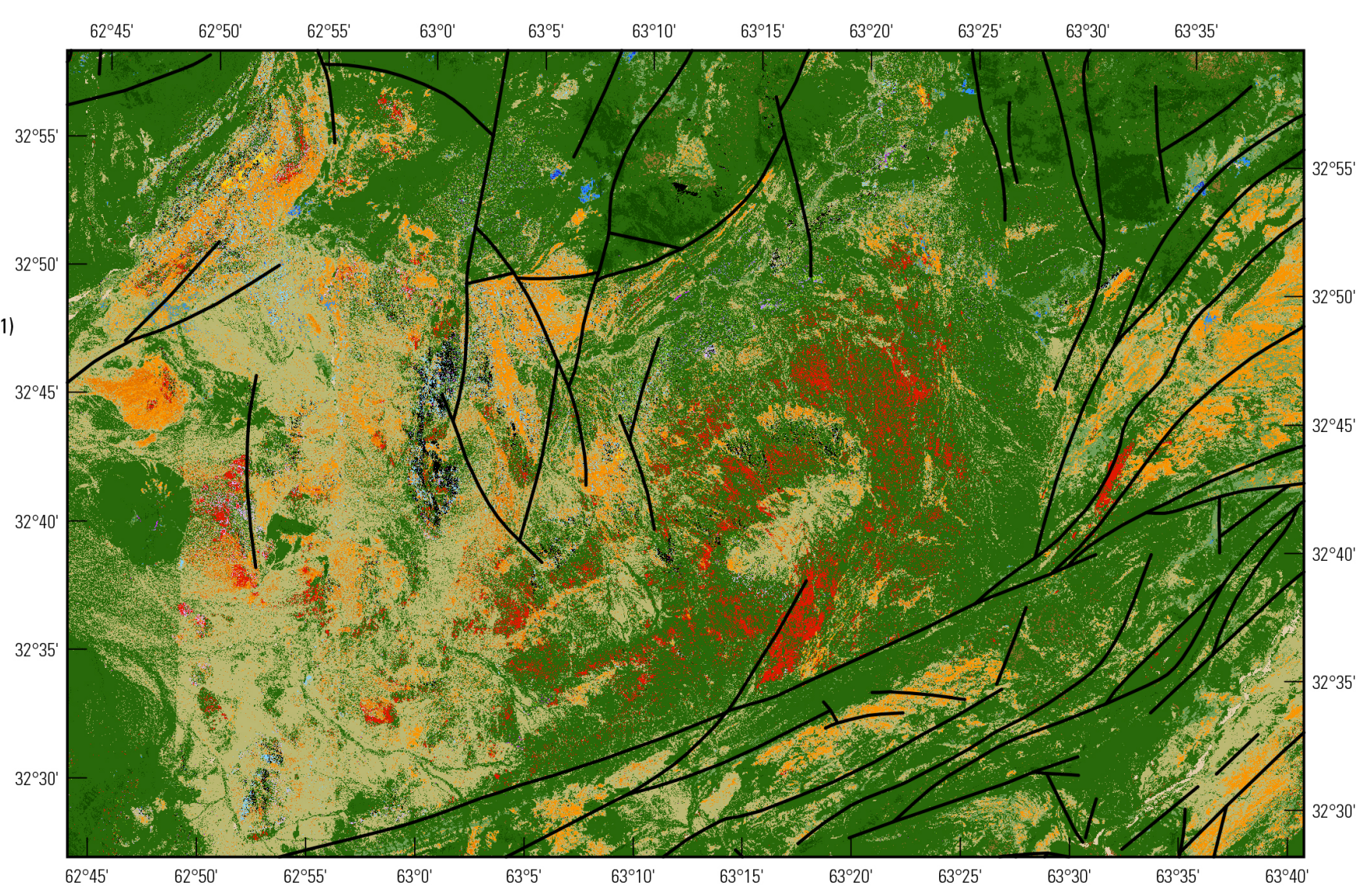

Base from U.S. Geological Survey

HyMap'M data of Afghanistan, 2007, 23-meter,

Transverse Mercator projection, Central Meridian 66 ${ }^{\circ}$,

Scale Factor 0.9996, Latitude of Origin $34^{\circ}$

World Geodetic System 1984
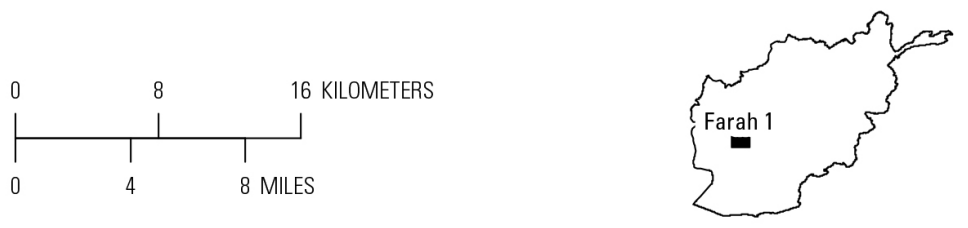

AFGHANISTAN LOCATION MAP

Figure 11. Map of carbonates, phyllosilicates, sulfates, altered minerals, and other materials derived from HyMap ${ }^{\mathrm{TM}}$ data in the Farah 1 area in Afghanistan (Kokaly and others, 2011, 2013). 


\section{EXPLANATION}

Class name (pixel count)

$\square$ Carbonate, iron-bearing $(28,400)$

Epidote or chlorite $(270,275)$

Kaolinite (alunite, pyrophyllite, or

dickite may be present) $(1,466$

Kaolinite (301)

Kaolinite and muscovite/clay/

carbonate $(19,946)$

Alunite (8)

Alunite and kaolinite (4)

Pyrophyllite (alunite or kaolinite

may be present) (1)

Jarosite (58)

Buddingtonite $(4,864)$

Hydrated silica (127)

_ I Subarea boundary

Lithologic contact

- Faults

Population center

- District Center

\section{Non-fuel minerals}

$\triangle \quad$ volcanogenic massive sulfide

$\square$ polymetallic vein

vein barite

unk $\mathrm{Hg}$

unk $\mathrm{Cu}$

Unnamed deposits are not labeled

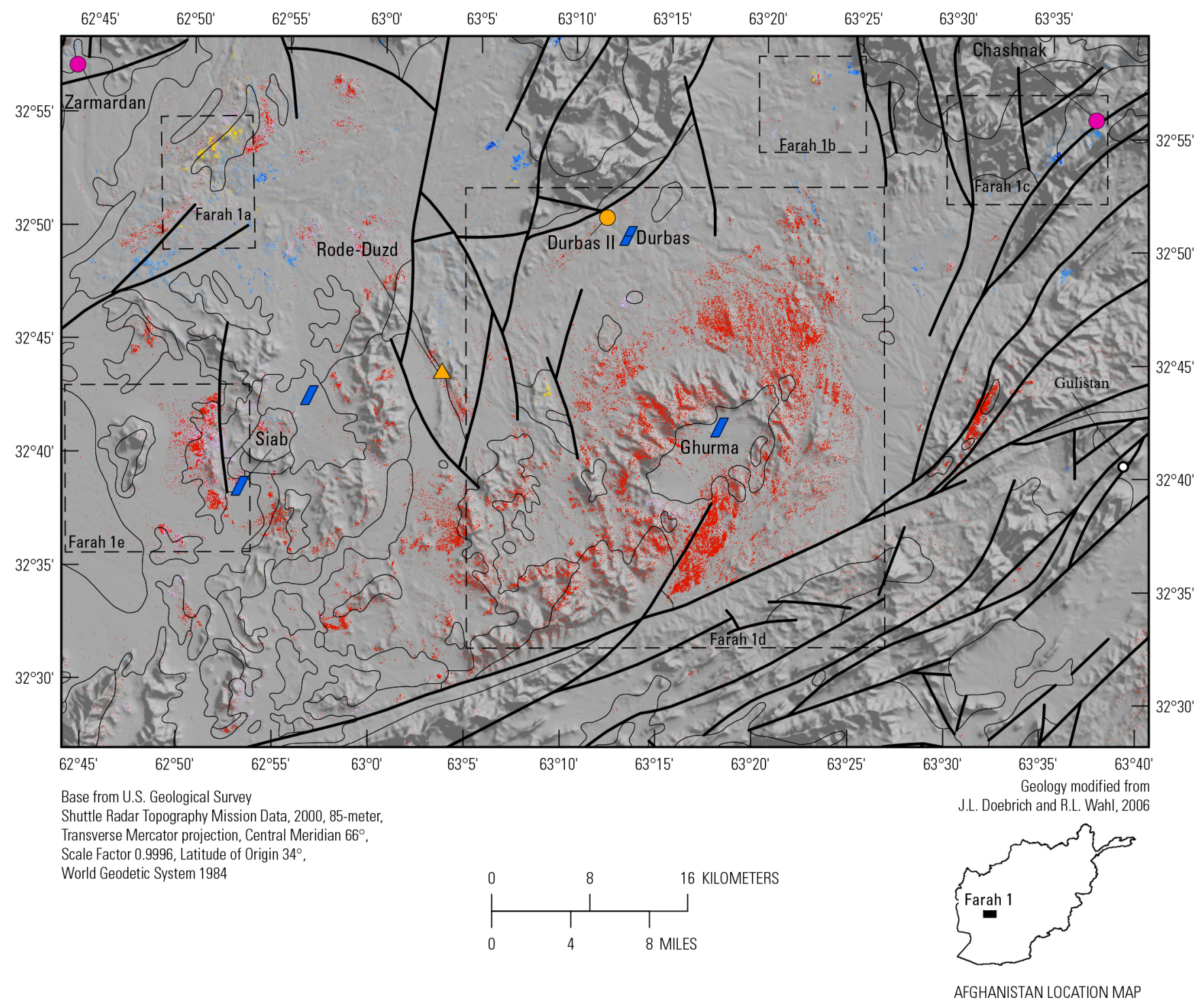

Figure 12. Map showing common alteration minerals derived from HyMap ${ }^{\mathrm{TM}}$ data in the Farah 1 area in Afghanistan (Kokaly and others, 2011, 2013). The detection of common alteration minerals is suggestive of possible past mineralization processes. 
Class name (pixel count)

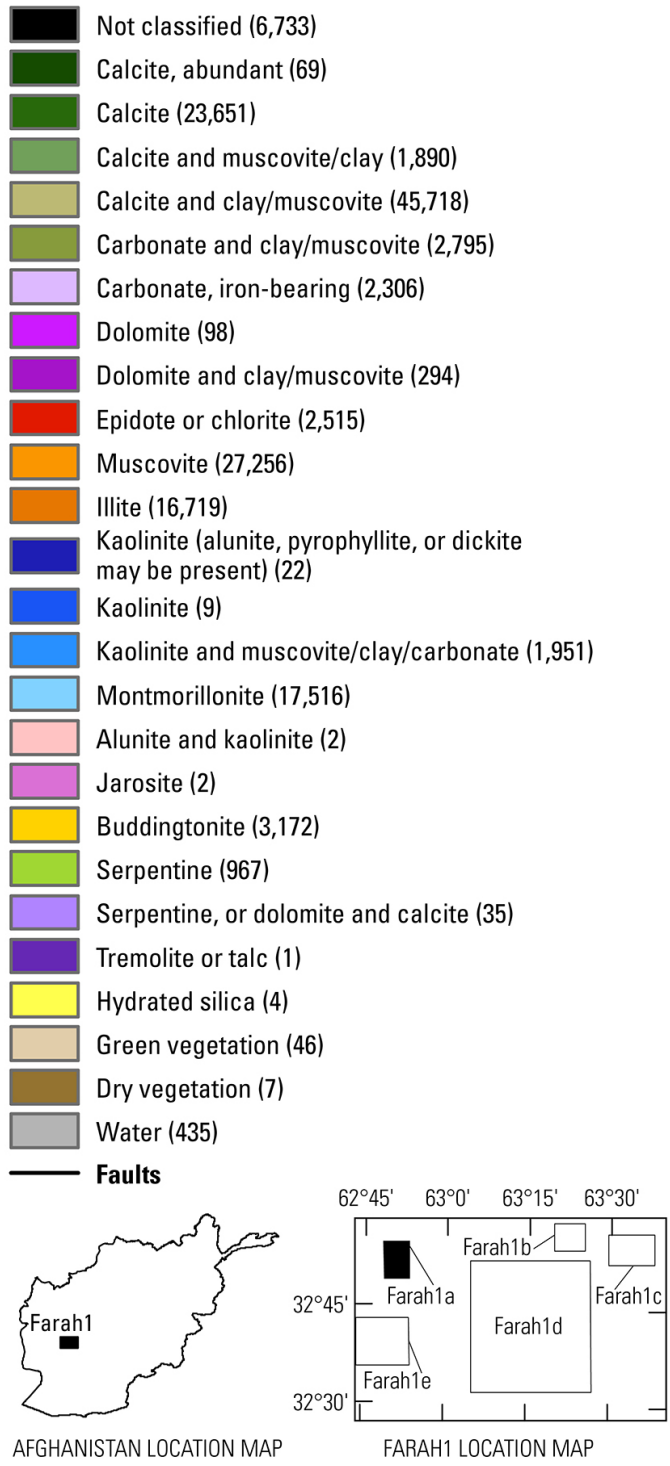

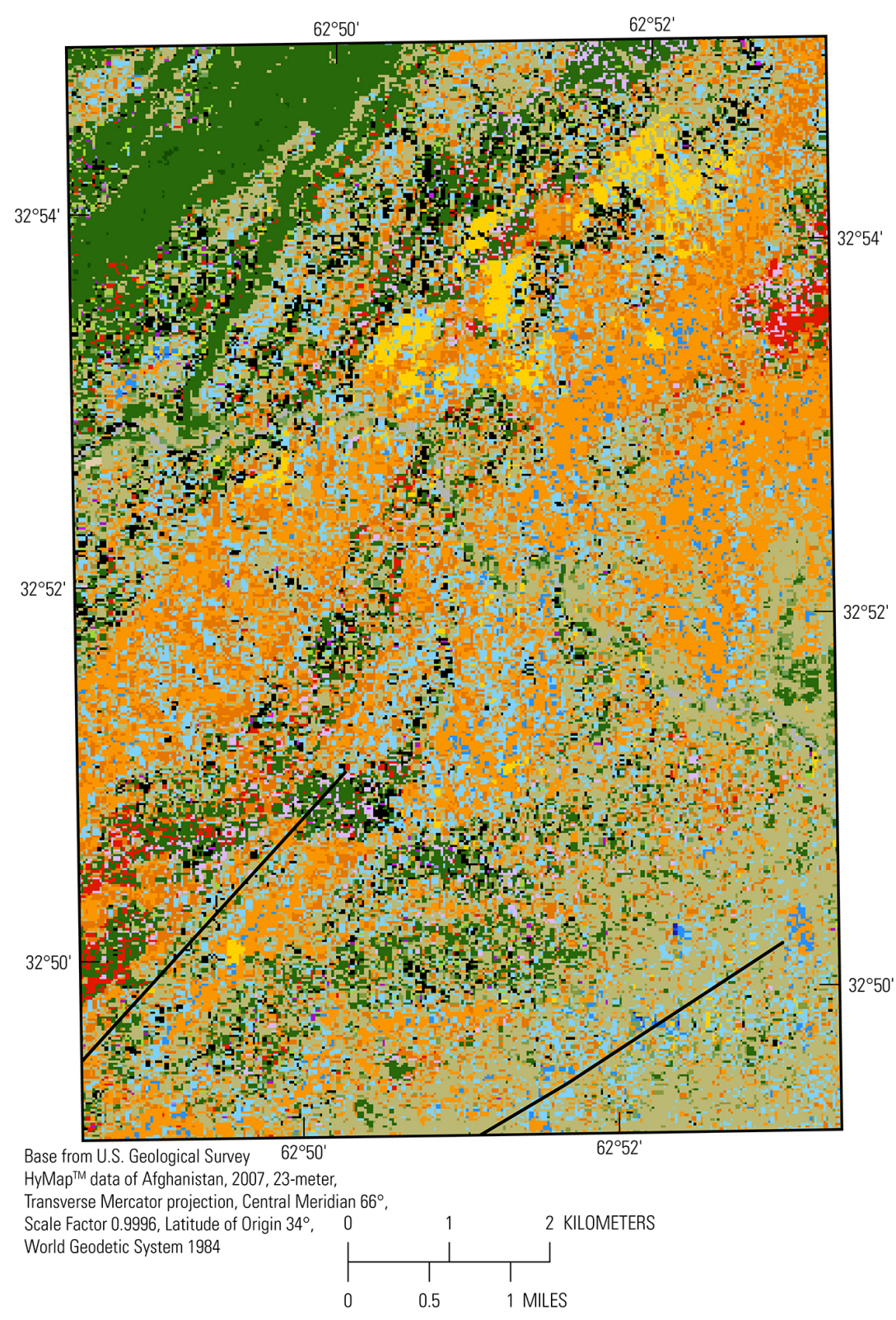

Figure 13. Map of carbonates, phyllosilicates, sulfates, altered minerals, and other materials derived from HyMap ${ }^{\text {TM }}$ data in the Farah 1 a subarea in Afghanistan (Kokaly and others, 2011, 2013). 


\section{EXPLANATION}

\section{Stratified rocks}

Oligocene

Eocene-Oligocene

Intrusive rocks

Eocene-Oligocen

Lithologic contac

Faults
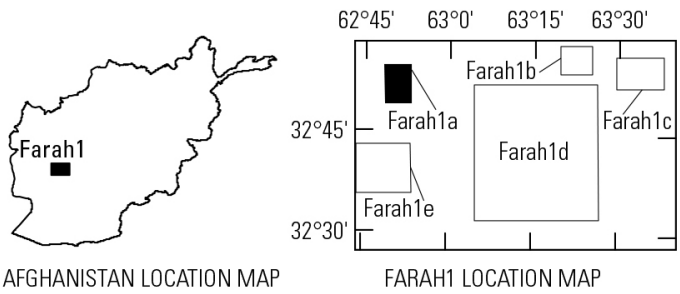

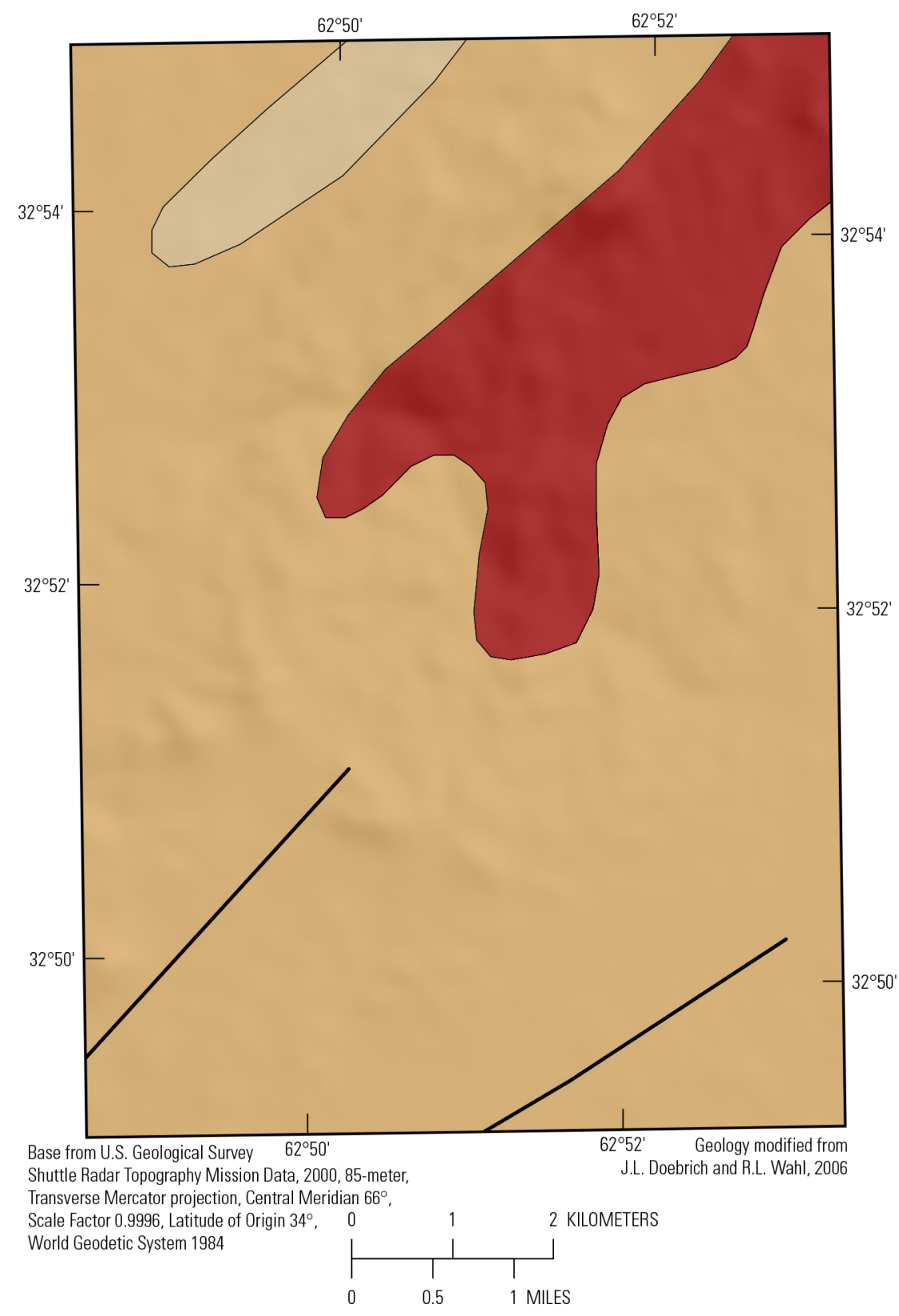

Figure 14. Geologic map of the Farah 1a subarea in Afghanistan (Abdullah and others, 1977; Doebrich and Wahl, 2006). 


\section{EXPLANATION}

\section{Class name (pixel count)}

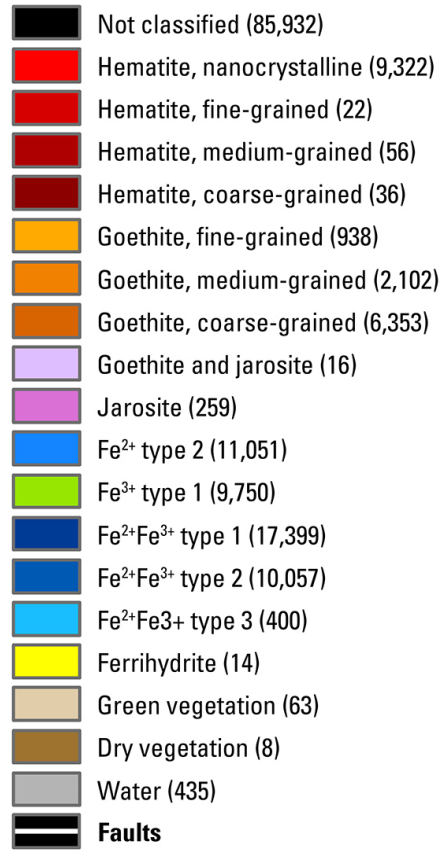
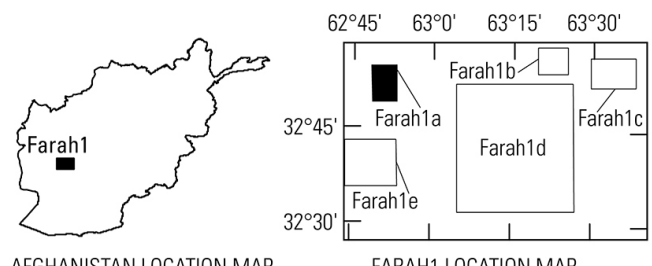

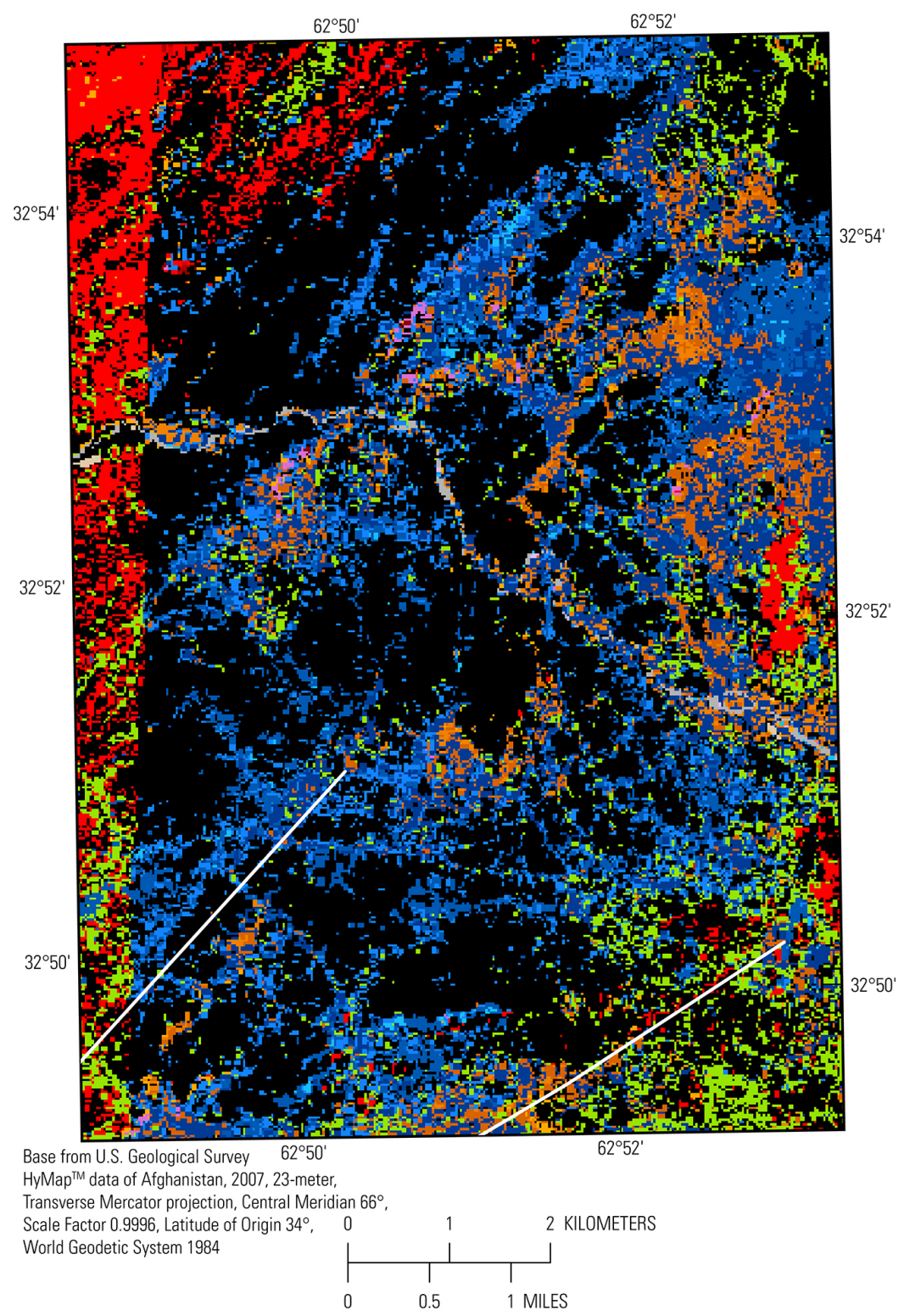

Figure 15. Map of iron-bearing minerals and other materials derived from HyMap ${ }^{T M}$ data in the Farah $1 \mathrm{a}$ subarea in Afghanistan (King and others, $2011 \mathrm{~b}$; Kokaly and others, 2013). The data for the extreme left side of this image were collected under adverse light conditions and have not been included in this analysis. 


\section{Farah $1 \mathrm{~b}$ Subarea}

The Farah $1 \mathrm{~b}$ subarea is of interest because of the presence of buddingtonite (fig. 16) and spatial association with volcanic rocks (figs. 10 and 17). The entire subarea, with the exception of its northeast corner, consists of stratified volcaniclastic rocks that include andesite, trachyte, dacite and rhyolite as well as limestone, siltstone, and sandstone (Abdullah and Chmyriov, 1977; Abdullah and others, 1977; Doebrich and Wahl, 2006). Carbonate minerals, particularly, calcite, carbonate group minerals (calcite and clay mixtures) and dolomite are the most dominant minerals mapped using the HyMap ${ }^{\mathrm{TM}}$ data in the subarea (fig. 16). Calcite is widely distributed in Farah $1 \mathrm{~b}$ and occurs in the alluvial washes and in sediments at lower elevations (fig. 18). Dolomitic minerals and dolomite with clay and serpentine are present on the west side of the Farah $1 \mathrm{~b}$ area. Dolomite appears to occur at the edges of topographic lows in circular patterns and these could be surficial expressions of subsurface alteration halos around a central heat source. The dolomite is commonly detected in close proximity to serpentine and montmorillonite. Kaolinites, muscovite, and illite are the dominant mineral mixtures on the eastern side of the subarea and form in two major zones or clusters (fig. 16). The kaolinite and kaolinite group minerals, which may include alunite and pyrophyllite, are spatially coincident with Quaternary valley sediments. Buddingtonite is mapped near the village of Gor Zanak along a 1.5 by $1.0 \mathrm{~km}$ region near the center of the subarea (fig. 19) that in Landsat Thematic Mapper (TM) images appears to be cut by numerous north-northwest trending dikes (fig. 18). In the HyMap ${ }^{\mathrm{TM}}$ data buddingtonite pixels are surrounded by pixels mapped as muscovite and chlorite/epidote (figs. 16 and 19). These mineral associations are suggestive of argillic alteration.

The iron-bearing minerals mapped in the Farah $1 \mathrm{~b}$ subarea (fig. 20 ) show distinct circular distribution patterns, in the upper and lower halves on the western side of the subarea, of $\mathrm{Fe}^{2+} \mathrm{Fe}^{3+}$ type 1 minerals which are surrounded by $\mathrm{Fe}^{3+}$ type 1, hematite and goethite minerals and lesser amounts of $\mathrm{Fe}^{2+} \mathrm{Fe}^{3+}$ type 2 and $\mathrm{Fe}^{2+}$ type 1 . These are located in the same circular areas that are ringed by and defined by the distribution of dolomite (fig. 16). A similar mineral distribution pattern, although more irregular in shape and with a greater abundance of $\mathrm{Fe}^{2+} \mathrm{Fe}^{3+}$ type 2 minerals and lesser amounts of hematite and goethite, is mapped in the southern half of the east side of the subarea. $\mathrm{Fe}^{2+} \mathrm{Fe}^{3+}$ type 2 and

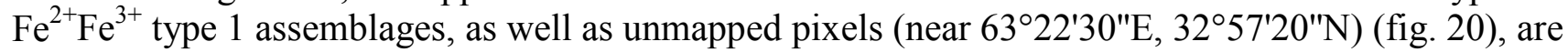
identified in the area mapped as buddingtonite (figs. 16 and 19). 


\section{EXPLANATION}

Class name (pixel count)

Not classified (856)

Calcite, abundant $(1,014)$

Calcite $(93,064)$

Calcite and muscovite/clay $(5,860)$

Calcite and clay/muscovite $(15,570)$

Carbonate and clay/muscovite $(2,699)$

Carbonate, iron-bearing (379)

Dolomite (82)

Dolomite and clay/muscovite (632)

Epidote or chlorite (438)

Muscovite $(1,975)$

Illite (514)

Kaolinite (alunite, pyrophyllite, or dickite

may be present) (70)

Kaolinite (12)

Kaolinite and muscovite/clay/carbonate (824)

Montmorillonite (1,329)

Buddingtonite (136)

Serpentine $(2,428)$

Serpentine, or dolomite and calcite (704)

Green vegetation (541)

Dry vegetation (261)

Water (275)

Faults
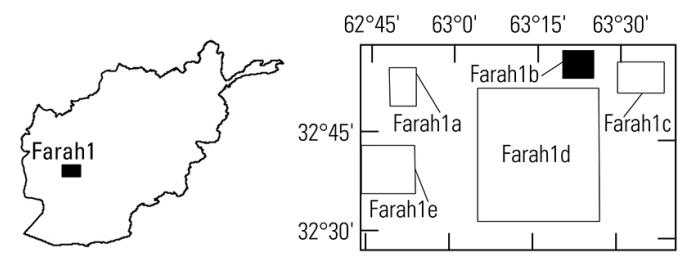

AFGHANISTAN LOCATION MAP

FARAHI LOCATION MAP

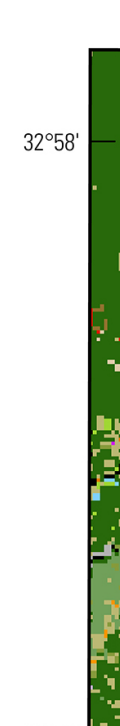

$63^{\circ} 20$

$63^{\circ} 22$

$63^{\circ} 24^{\prime}$

$32^{\circ} 56^{\prime}$
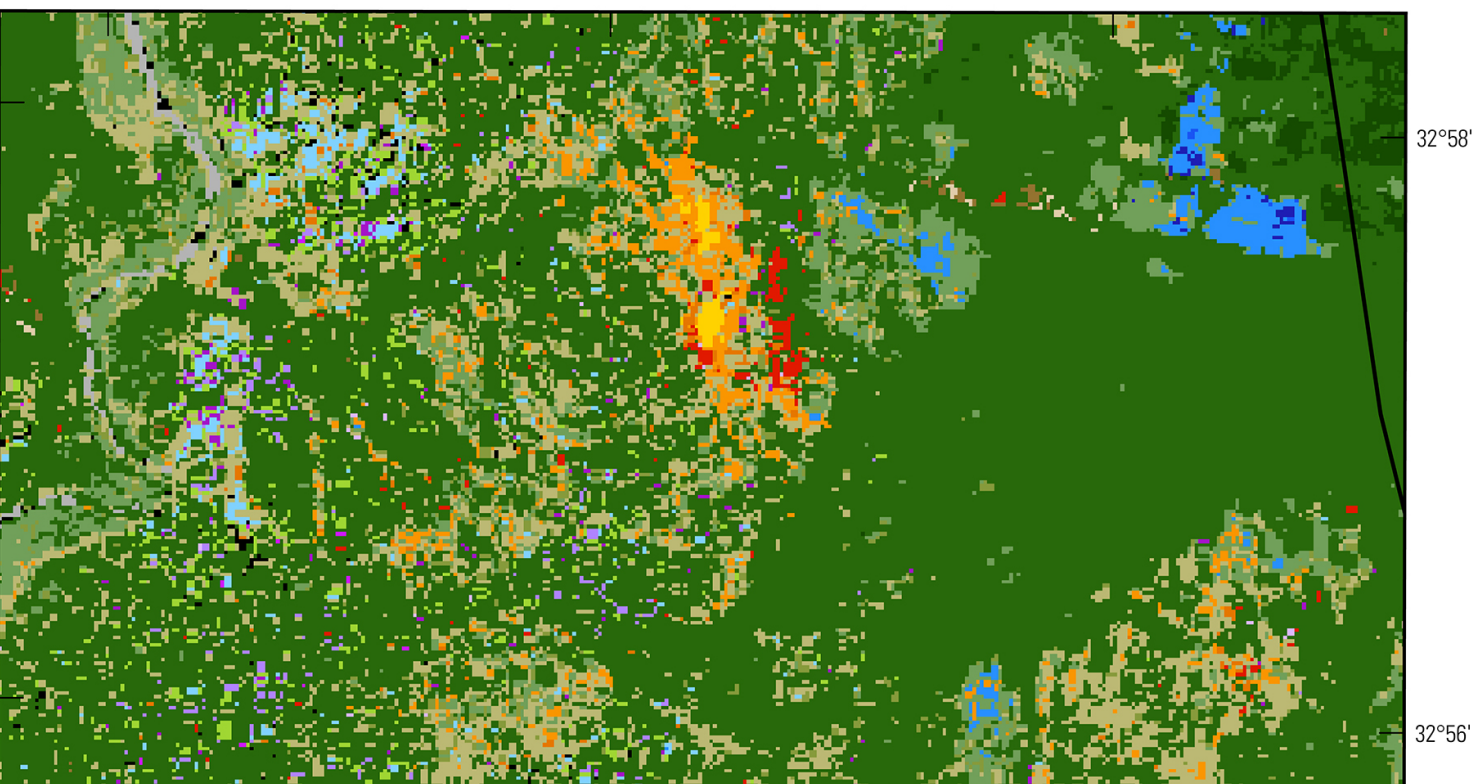

1.

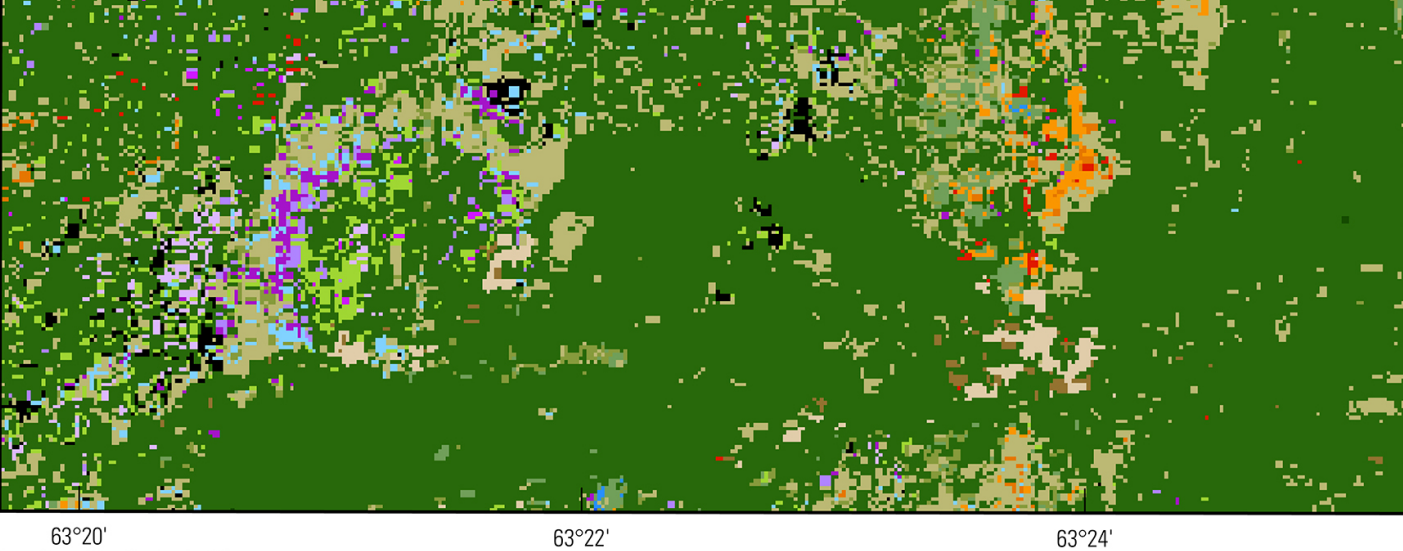

$63^{\circ} 20^{\circ}$

$63^{\circ} 22$

$63^{\circ} 24^{\prime}$

Base from U.S. Geological Survey

HyMap ${ }^{T M}$ data of Afghanistan, 2007, 23-meter,

年,

Origin $34^{\circ}$,

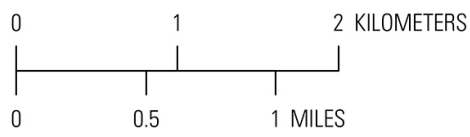

Figure 16. Map of carbonates, phyllosilicates, sulfates, altered minerals, and other materials derived from HyMap ${ }^{\mathrm{TM}}$ data in the Farah $1 \mathrm{~b}$ subarea in Afghanistan (Kokaly and others, 2011, 2013). 


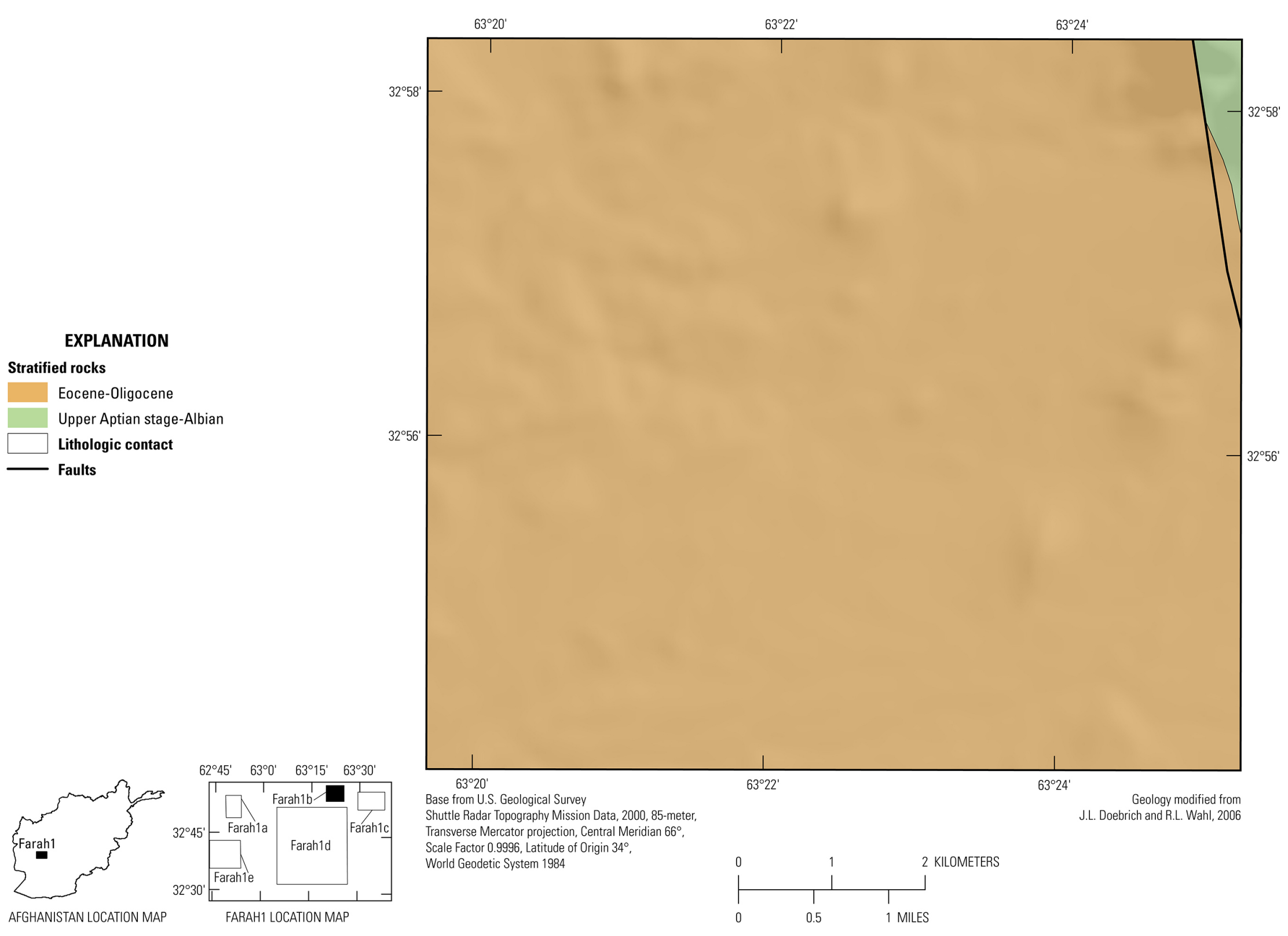

Figure 17. Geologic map of the Farah 1b subarea in Afghanistan (Abdullah and Chmyriov, 1977; Abdullah and others, 1977; Doebrich and Wahl, 2006). 


\section{EXPLANATION}

Lithologic contact

- Faults
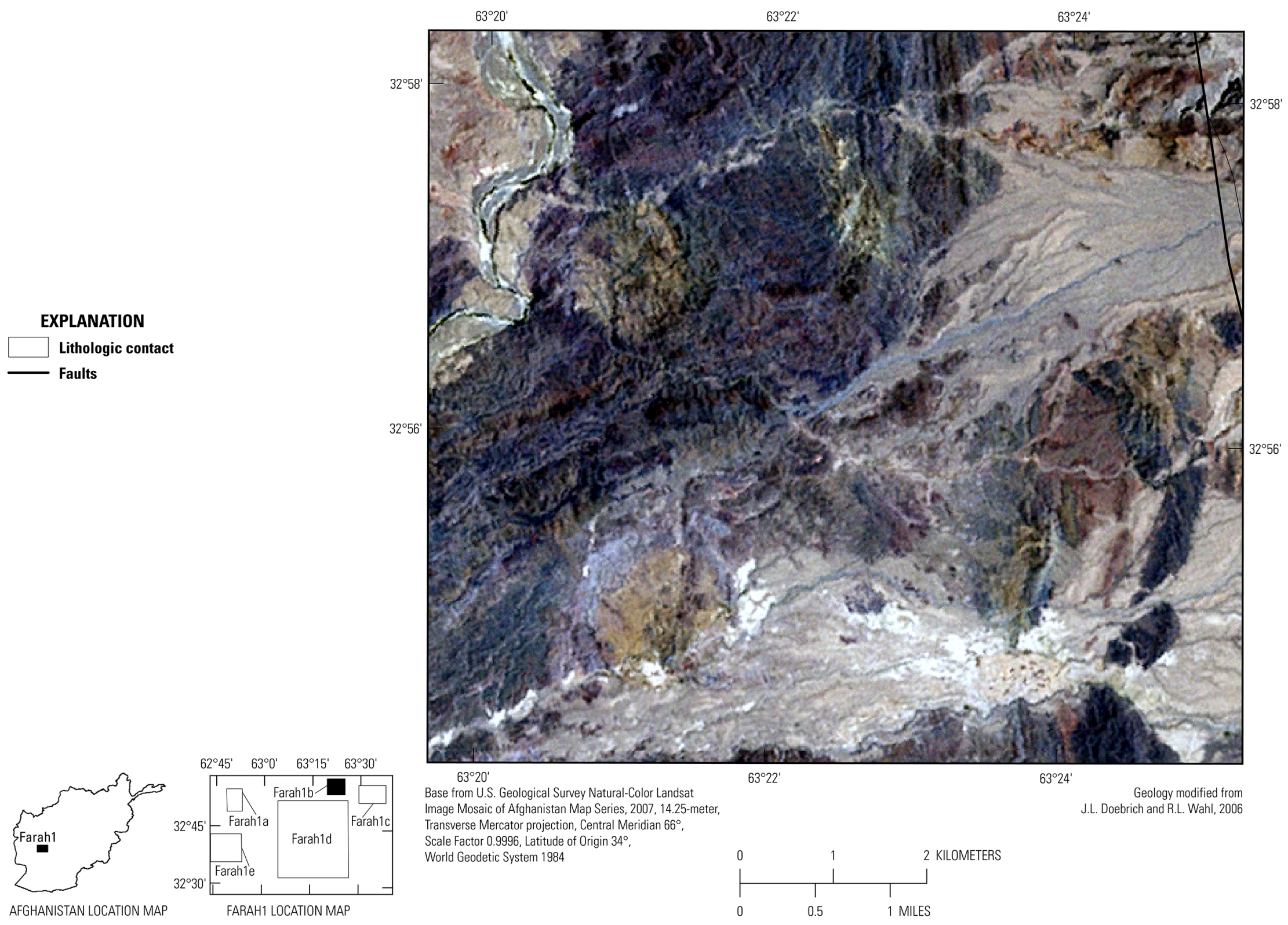

Figure 18. Contrast-enhanced stretch of the natural-color composite of Landsat Thematic Mapper bands from Davis (2007) of the Farah $1 \mathrm{~b}$ area in Afghanistan. 


\section{EXPLANATION}

Class name (pixel count)

$\square$ Carbonate, iron-bearing (379)

Epidote or chlorite (438)

Kaolinite (alunite, pyrophyllite, or dickite

may be present) (70)

Kaolinite (12)

Kaolinite and muscovite/clay/carbonate (824)

Buddingtonite (136)

Lithologic contact

- Faults

- Village

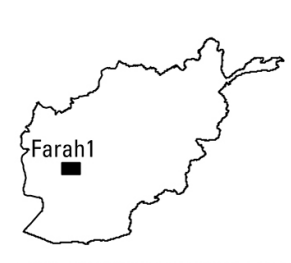

AFGHANISTAN LOCATION MAP

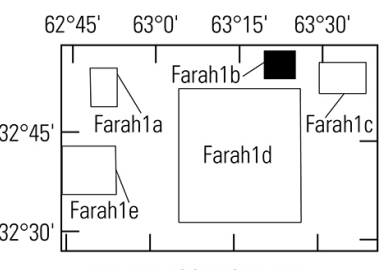

FARAHI LOCATION MAP

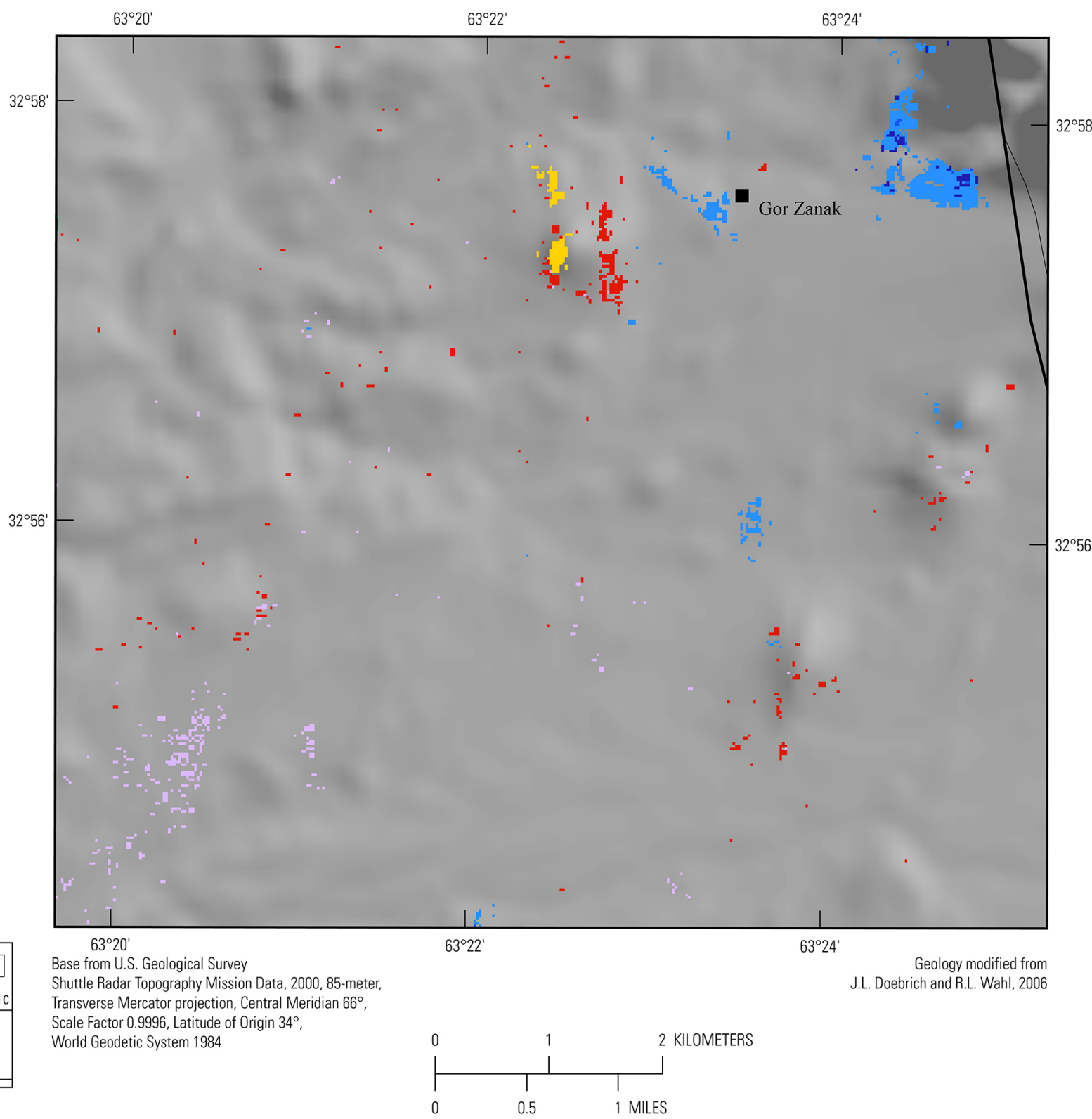

Figure 19. Map showing common alteration minerals derived from HyMap ${ }^{T M}$ data in the Farah $1 \mathrm{~b}$ subarea in Afghanistan (Kokaly and others, 2011, 2013). The spectroscopic detection of common alteration minerals is suggestive of possible past mineralization processes. 


\section{EXPLANATION}

Class name (pixel count)

Not classified $(91,998)$

Hematite, nanocrystalline $(16,229)$

Hematite, fine-grained (65)

Hematite, medium-grained (84)

Hematite, coarse-grained (45)

Goethite, fine-grained (948)

Goethite, medium-grained $(1,205)$

Goethite, coarse-grained (482)

Goethite and jarosite (13)

Jarosite (21)

$\mathrm{Fe}^{2+}$ type $2(2,706)$

$\mathrm{Fe}^{3+}$ type $1(8,535)$

Fe3+ type 2 (1)

$\mathrm{Fe}^{2+} \mathrm{Fe}^{3+}$ type $1(3,484$

$\mathrm{Fe}^{2+} \mathrm{Fe}^{3+}$ type $2(2,425)$

$\mathrm{Fe}^{2+} \mathrm{Fe}^{3+}$ type $3(12)$

Green vegetation (858)

Dry vegetation (277)

Water (275)

Faults
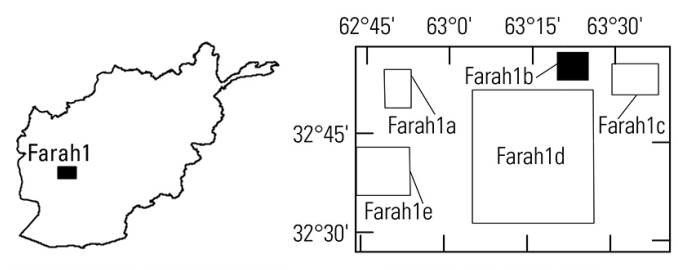

AFGHANISTAN LOCATION MAP

FARAH1 LOCATION MAP

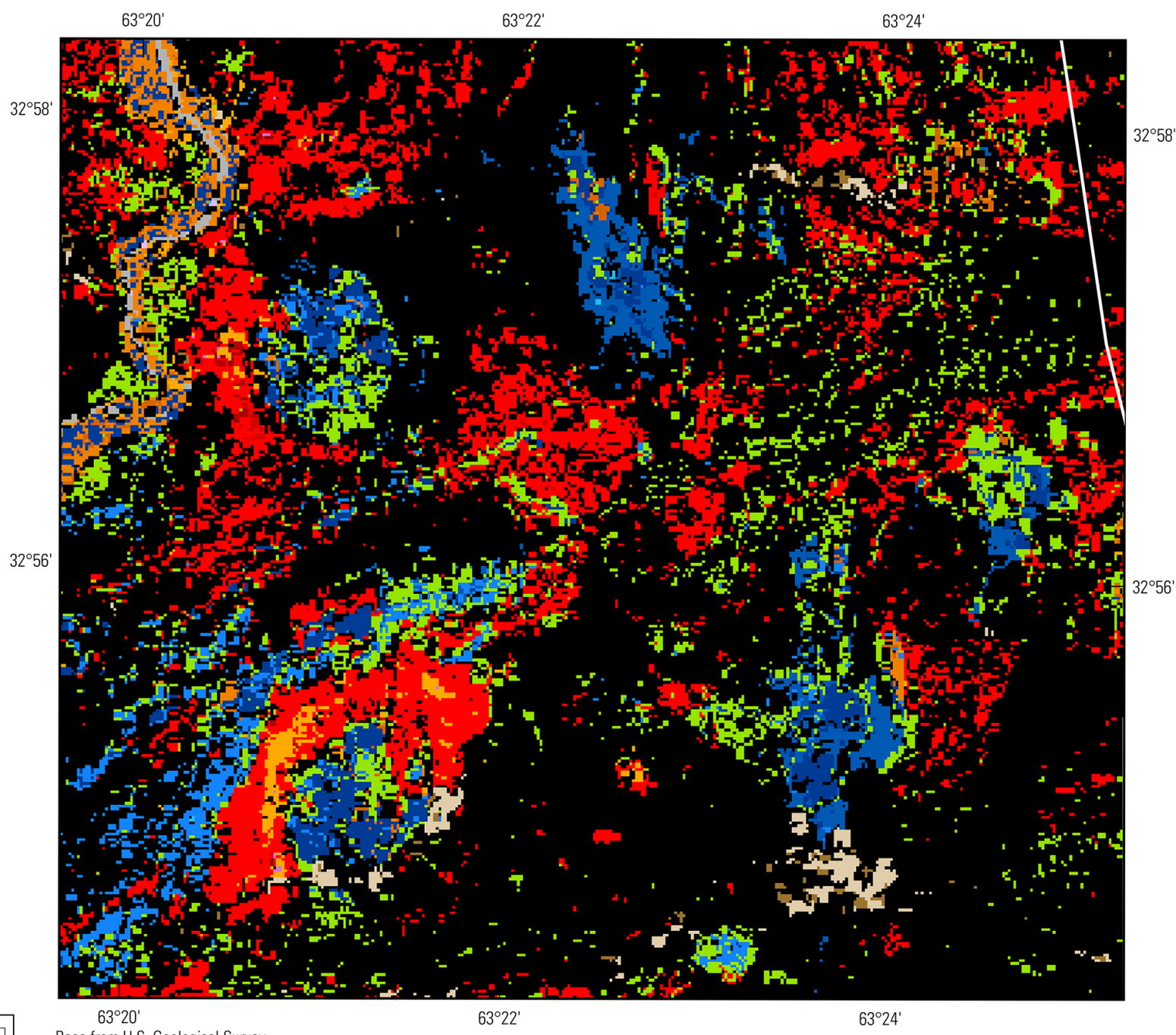

Base from U.S. Geological Survey
HyMap ${ }^{\text {TM }}$ data of Afghanistan, 2007, 23-meter

Transverse Mercator projection, Central Meridian $66^{\circ}$

Scale Factor 0.9996, Latitude of Origin $34^{\circ}$.

World Geodetic System 1984

Figure 20. Map of iron-bearing minerals and other materials derived from HyMap ${ }^{\mathrm{TM}}$ data in the Farah $1 \mathrm{~b}$ area in Afghanistan (King and others, 2011b; Kokaly and others, 2013). 


\section{Farah 1c Subarea}

The Farah subarea 1c is dominated by a large circular feature that is a topographic high (fig. 21). The calcite-rich is area is mapped as Lower Cretaceous stratified rocks which are bounded on the southwest by Eocene-Oligocene volcanic rocks (Abdullah and Chmyriov, 1977; Abdullah and others 1977; Doebrich and Wahl, 2006) (fig. 22). Clusters of kaolinite (possibly with alunite, pyrophyllite or dickite) and kaolinite group minerals (kaolinite and clay) occur along the margins of the calcite-rich body and along a northeast-trending, fault-controlled valley to the east (fig. 23). Calcite and clay mixtures along with muscovite are also randomly present in the subarea.

Iron hydroxide, goethite, $\mathrm{Fe}^{3+}$ type 1 and $\mathrm{Fe}^{2+} \mathrm{Fe}^{3+}$ assemblages are the dominant iron-bearing minerals in the HyMap ${ }^{\mathrm{TM}}$ data in the subarea (fig. 24), particularly in the northeast-trending valley that contains the kaolinite. The Chashnak Hg-occurrence is coincident with the iron hydroxide and goethite minerals mapped along the northeast-trending valley (figs. 22-24). A small circular cluster of jarosite lies along the southern margin of the calcite-rich circular feature in the southern most part of the subarea. 
EXPLANATION

Lithologic contact

- Faults

Non-fuel minerals

unk $\mathrm{Hg}$

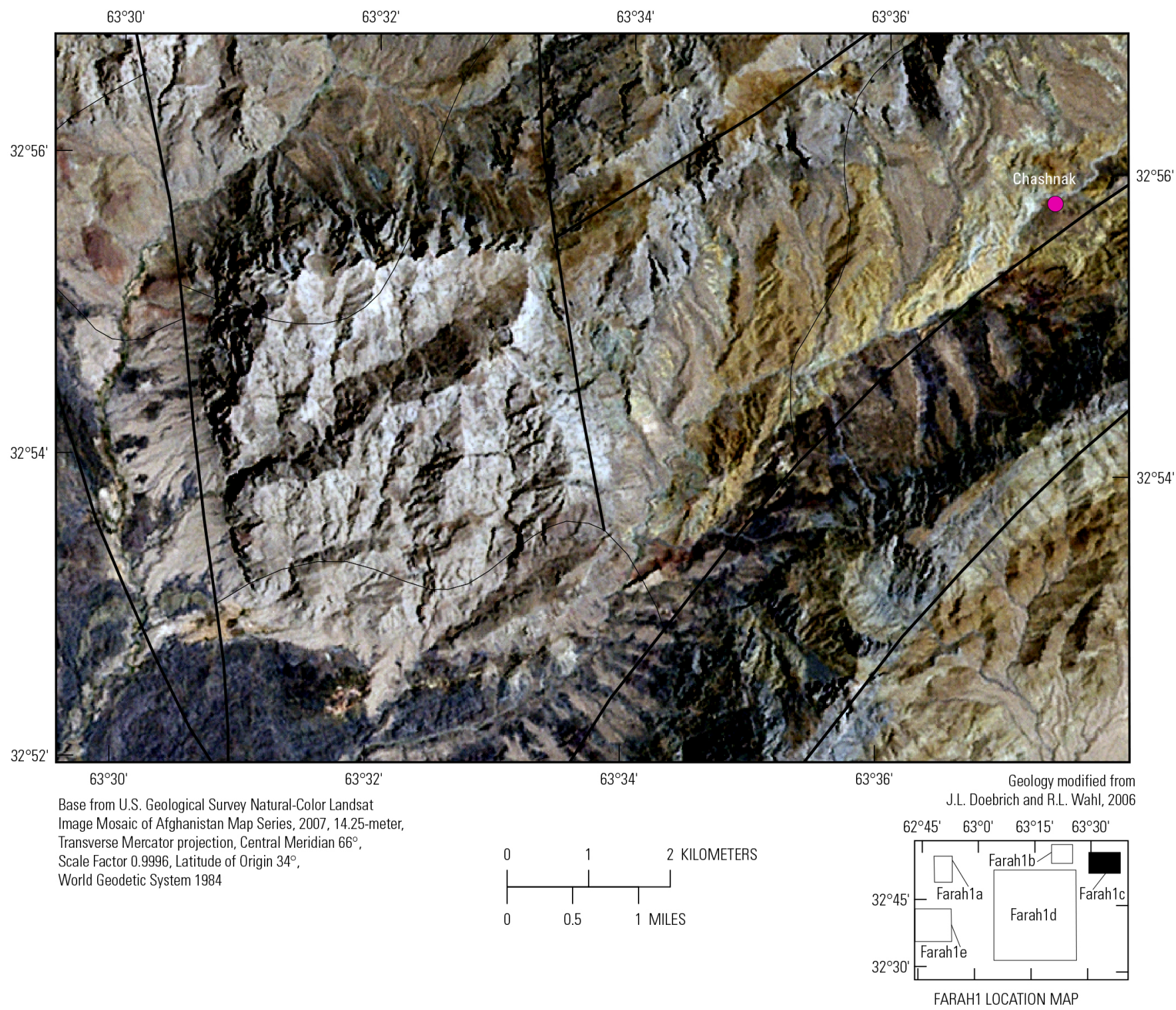

Figure 21. Contrast-enhanced stretch of the natural-color composite of Landsat Thematic Mapper bands from Davis (2007) of the Farah 1c subarea in Afghanistan. 


\section{EXPLANATION}

\section{Stratified rocks}

Eocene-Oligocene

Upper Aptian stage-Albian

Barremian-Aptian

Valanginian-Hauterivian

Volcanic field

Lithologic contact

Faults

Non-fuel minerals

unk $\mathrm{Hg}$

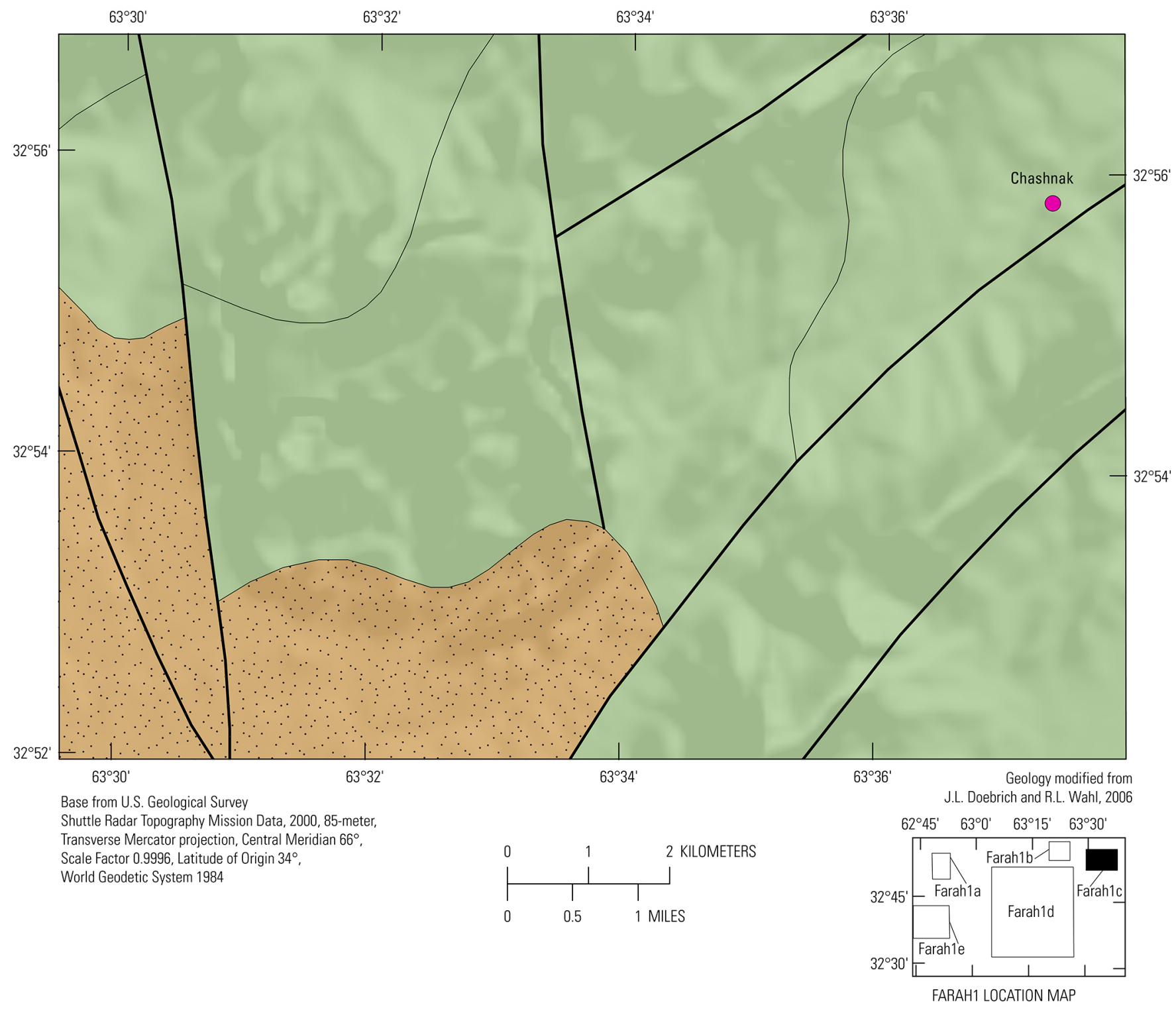

Figure 22. Geologic map of the Farah 1c subarea in Afghanistan (Abdullah and Chmyriov, 1977; Abdullah and others, 1977; Doebrich and Wahl, 2006). 


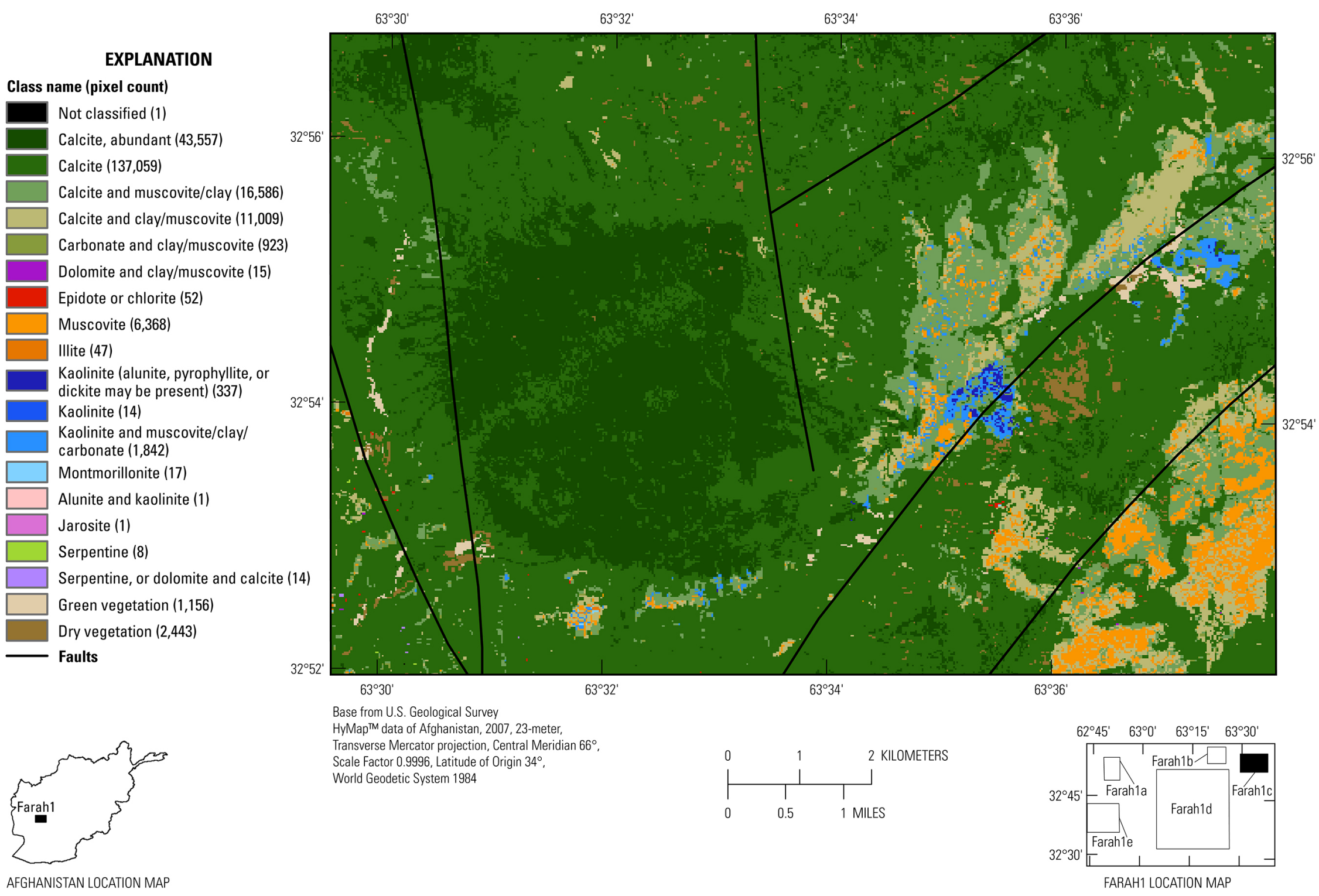

Figure 23. Map of carbonates, phyllosilicates, sulfates, altered minerals, and other materials derived from HyMap ${ }^{\mathrm{TM}}$ data in the Farah $1 \mathrm{c}$ subarea in Afghanistan (Kokaly and others, 2011, 2013). 


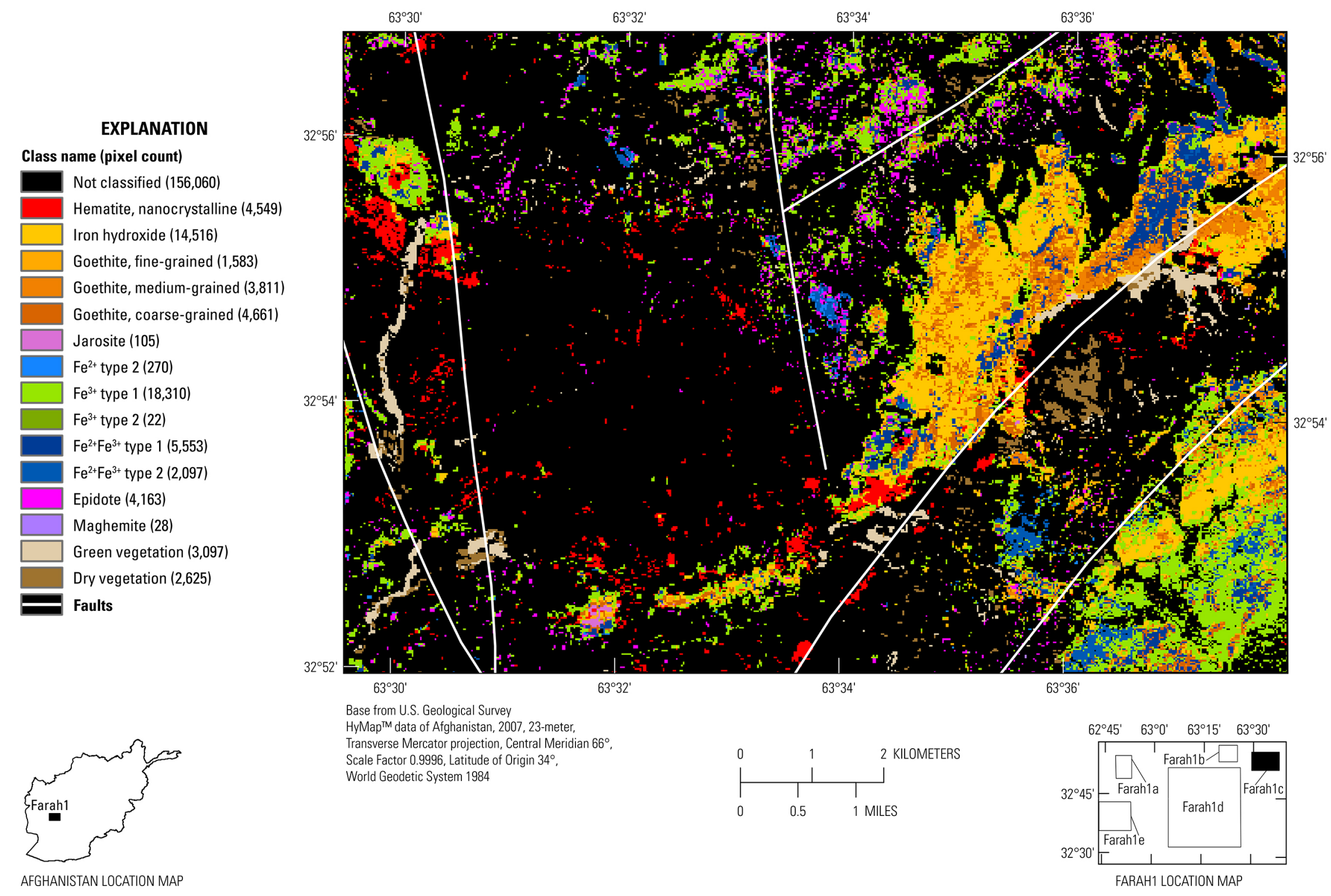

Figure 24. Map of iron-bearing minerals and other materials derived from HyMap ${ }^{\mathrm{TM}}$ data in the Farah $1 \mathrm{c}$ subarea in Afghanistan (King and others, 2011b; Kokaly and others, 2013). 


\section{Farah 1d Subarea}

The Farah 1d subarea is the largest in the Farah 1area, and is composed of Eocence-Oligocence volcanic rocks (andesite, trachyte, basalt, dacite, rhyolite, ignimbrites) and sediments (sandstone, siltstone, and limestone) (fig. 25). Oligocene intrusives are also present (Abdullah and Chmyriov, 1977; Abdullah and others, 1977; Doebrich and Wahl, 2006). An Oligocene intrusion, near the center of the subarea, and the northeast-trending fault zone in the southern part are the most prominent features. It has been noted previously that the subarea contains known mineral occurrences including polymetallic vein at Ghurma $\left(63^{\circ} 17^{\prime} 41^{\prime \prime} \mathrm{E}, 32^{\circ} 41^{\prime} 45^{\prime \prime} \mathrm{N}\right)$ and volcanogenic massive sulfide at Durbas II 63 $11^{\prime} 47^{\prime \prime} \mathrm{E}, 32^{\circ} 50^{\prime}$

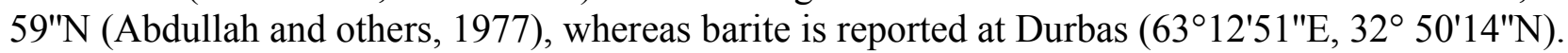

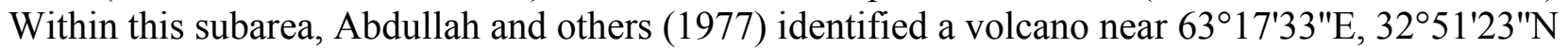
(fig. 25), and reviews of the Landsat TM data images suggest additional volcanic vents in the vicinity (figs. 25 and 26).

Minerals mapped in the Farah 1d subarea include epidote or chlorite, calcite, carbonate group minerals (calcite and clays), muscovite, illite, and minor montmorillonite (fig. 27). Epidote or chlorite minerals intermixed with calcitic minerals are widespread and surround the central Oligocene intrusion. Limited occurrences of dolomite and iron-bearing carbonate are present in the northern portion of the subarea in stratified units and in isolated patches in the Eocene-Oligocene extrusive rocks (rhyolite and dacite) (figs. 25 and 27). Buddingtonite is also mapped in approximately the north-south center of the western half of the subarea and occurs with muscovite, illite, and montmorillonite (fig. 28). The associated rocks are fault-bounded Oligocene intrusives (granite, granodiorite, granosyenites, and granite porphyry) (Abdullah and Chmyriov, 1977; Doebrich and Wahl, 2006) (fig. 26).

Assemblages of $\mathrm{Fe}^{2+} \mathrm{Fe}^{3+}$ and $\mathrm{Fe}^{3+}$ type 1 minerals are the foremost iron-bearing minerals mapped in the subarea (fig. 29). A small cluster of jarosite is mapped in the fault-bounded, Oligocene intrusive rocks (near 638 $8^{\prime} 12.62^{\prime \prime} \mathrm{E}, 32^{\circ} 42^{\prime} 20.88^{\prime \prime} \mathrm{N}$ ). Lesser amounts of hematite and goethite are mapped in the southeast and northwest corners of the subarea. Unmapped areas are largely calcite-rich and are not classified in the iron-bearing materials map. 


\section{EXPLANATION}

\section{Stratified rocks}

Oligocene

Eocene-Oligocene

Upper Aptian stage-Albian

Barremian-Aptian

Valanginian-Hauterivian

Berriasian-Valanginian

Intrusive rocks

Oligocene

Eocene-Oligocene

Volcanic field

Lithologic contact

\section{aults}

Non-fuel minerals

$\triangle$ volcanogenic massive sulfide

$\square \quad$ polymetallic vein

A vein barite

$\vec{x}$ Volcano

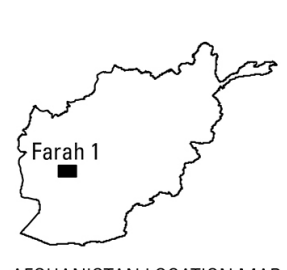

AFGHANISTAN LOCATION MAP

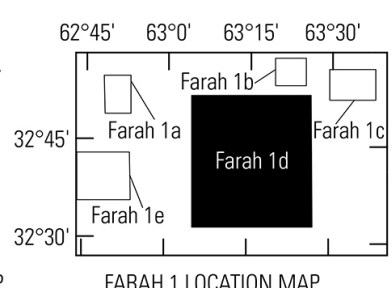

FARAH 1 LOCATION MAP

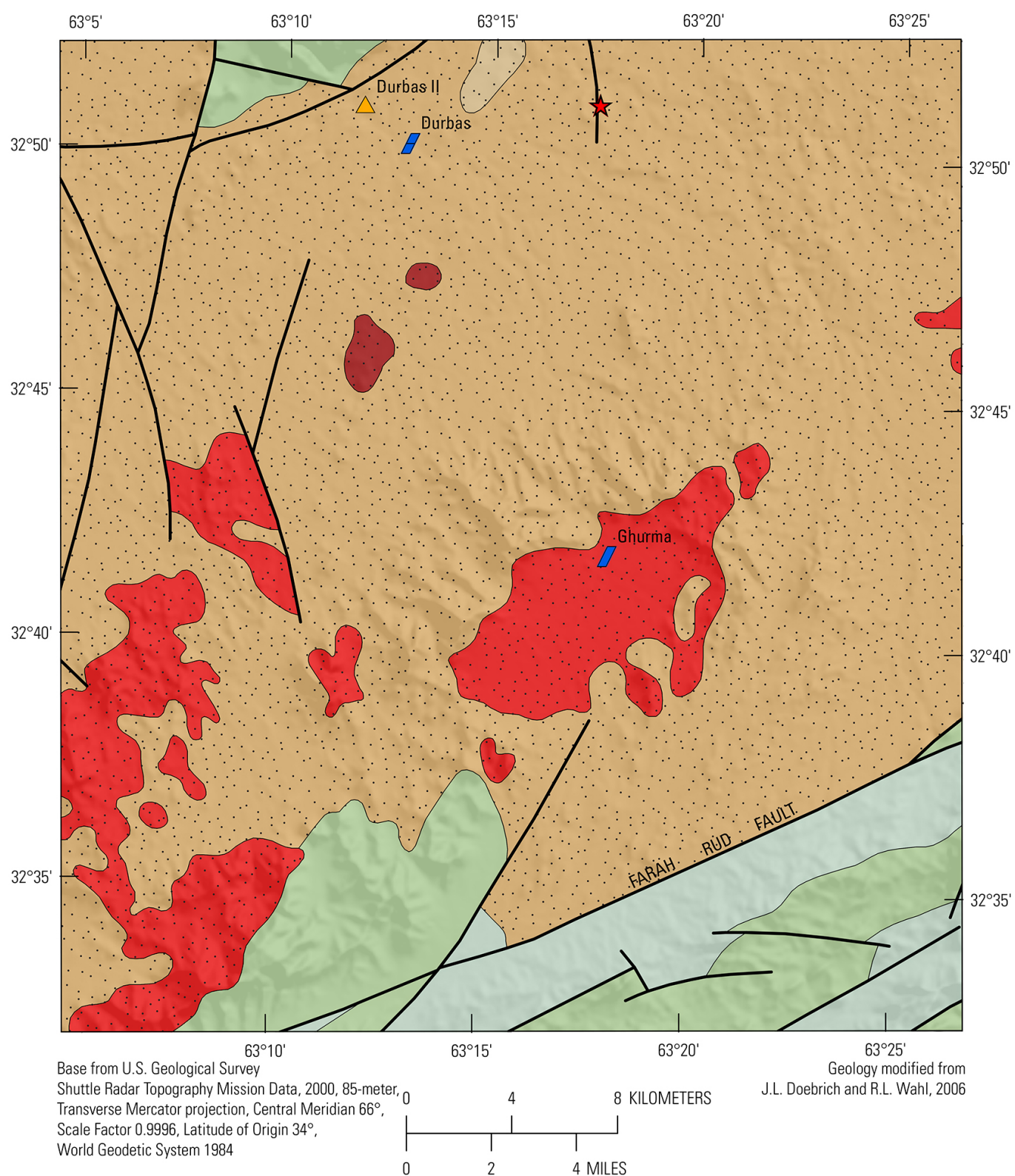

Figure 25. Geologic map and known mineral occurrences in the Farah 1d subarea in Afghanistan (Abdullah and Chmyriov, 1977; Abdullah and others, 1977; Doebrich and Wahl, 2006). 


\section{EXPLANATION \\ Lithologic contact \\ - Faults \\ Non-fuel minerals}
$\triangle$ volcanogenic massive sulfide
polymetallic vein
vein barite
文 Volcano
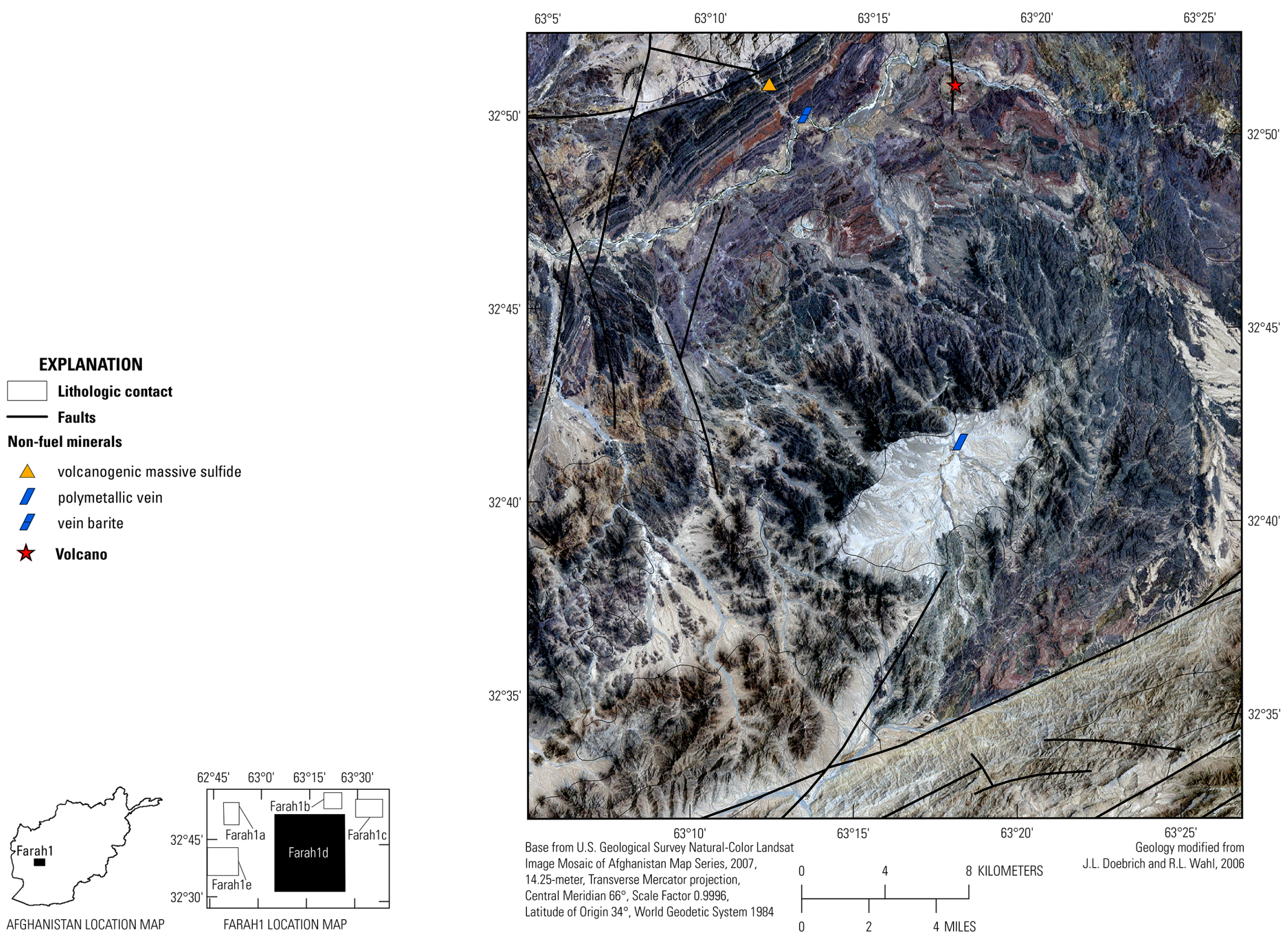

Figure 26. Contrast-enhanced sretch of the natural-color composite of Landsat Thematic Mapper bands from Davis (2007) of the Farah 1d subarea in Afghanistan. The large, light-colored oblong area in the bottom half of the image is mapped as Oligocene intrusive rocks (Abdullah and Chmyriov, 1977; Doebrich and Wahl, 2006). 


\section{EXPLANATION}

Class name (pixel count)

Not classified $(20,554)$

Calcite, abundant $(17,975)$

Calcite $(1,478,610)$

Calcite and muscovite/clay $(29,312)$

Calcite and clay/muscovite $(471,787)$

Carbonate and clay/muscovite $(10,696)$

Carbonate, iron-bearing $(4,881)$

Dolomite $(1,521)$

Dolomite and clay/muscovite $(2,612$

Epidote or chlorite $(184,115)$

Muscovite $(89,697)$

Illite $(64,398$

Kaolinite (alunite, pyrophyllite, or dickite may be present) (39)

Kaolinite (27)

Kaolinite and muscovite/clay/carbonate $(1,699)$

Montmorillonite $(19,020)$

Jarosite (9)

Buddingtonite (582)

Serpentine $(18,525)$

Serpentine, or dolomite and calcite $(6,357)$

Tremolite or talc (8)

Hydrated silica (9)

Green vegetation $(2,553)$

Dry vegetation $(5,712)$

Water $(1,168)$

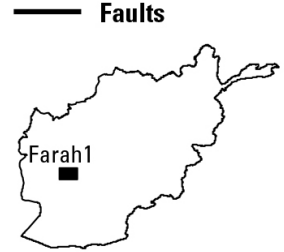

AFGHANISTAN LOCATION MA

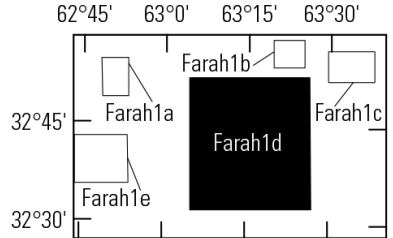

FARAH1 LOCATION MAP $63^{\circ} 5^{\prime}$

$63^{\circ} 10^{\prime}$

$63^{\circ} 15^{\prime}$

$63^{\circ} 20^{\prime}$

63025

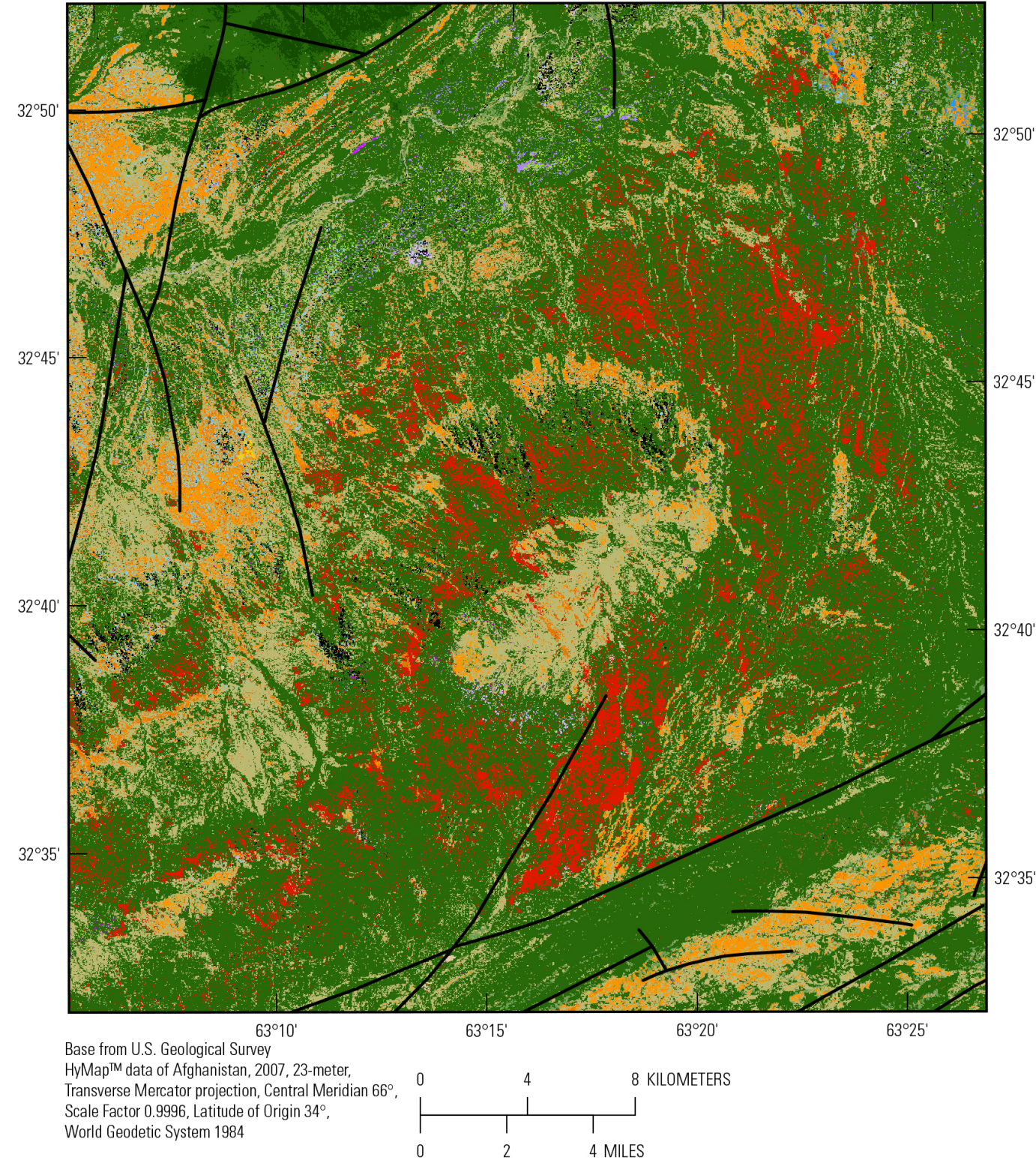

Figure 27. Map of carbonates, phyllosilicates, sulfates, altered minerals, and other materials derived from HyMap ${ }^{\mathrm{TM}}$ data in the Farah $1 \mathrm{~d}$ subarea in Afghanistan (Kokaly and others, 2011, 2013). 


\section{EXPLANATION}

Class name (pixel count)

$\square$ Carbonate, iron-bearing $(4,881)$

Epidote or chlorite $(184,115)$

Kaolinite (alunite, pyrophyllite, or dickite may be present) (39)

Kaolinite (27)

Kaolinite and muscovite/clay/carbonate $(1,699)$

Jarosite (9)

Buddingtonite (582)

Hydrated silica (9)

Lithologic contact

- Faults

Non-fuel minerals

$\triangle$ volcanogenic massive sulfide

$\square$ polymetallic vein

a vein barite

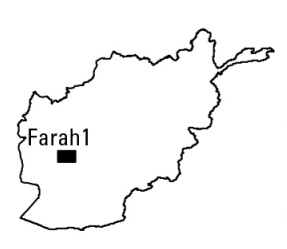

AFGHANISTAN LOCATION MAP

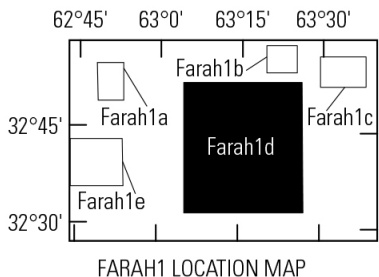

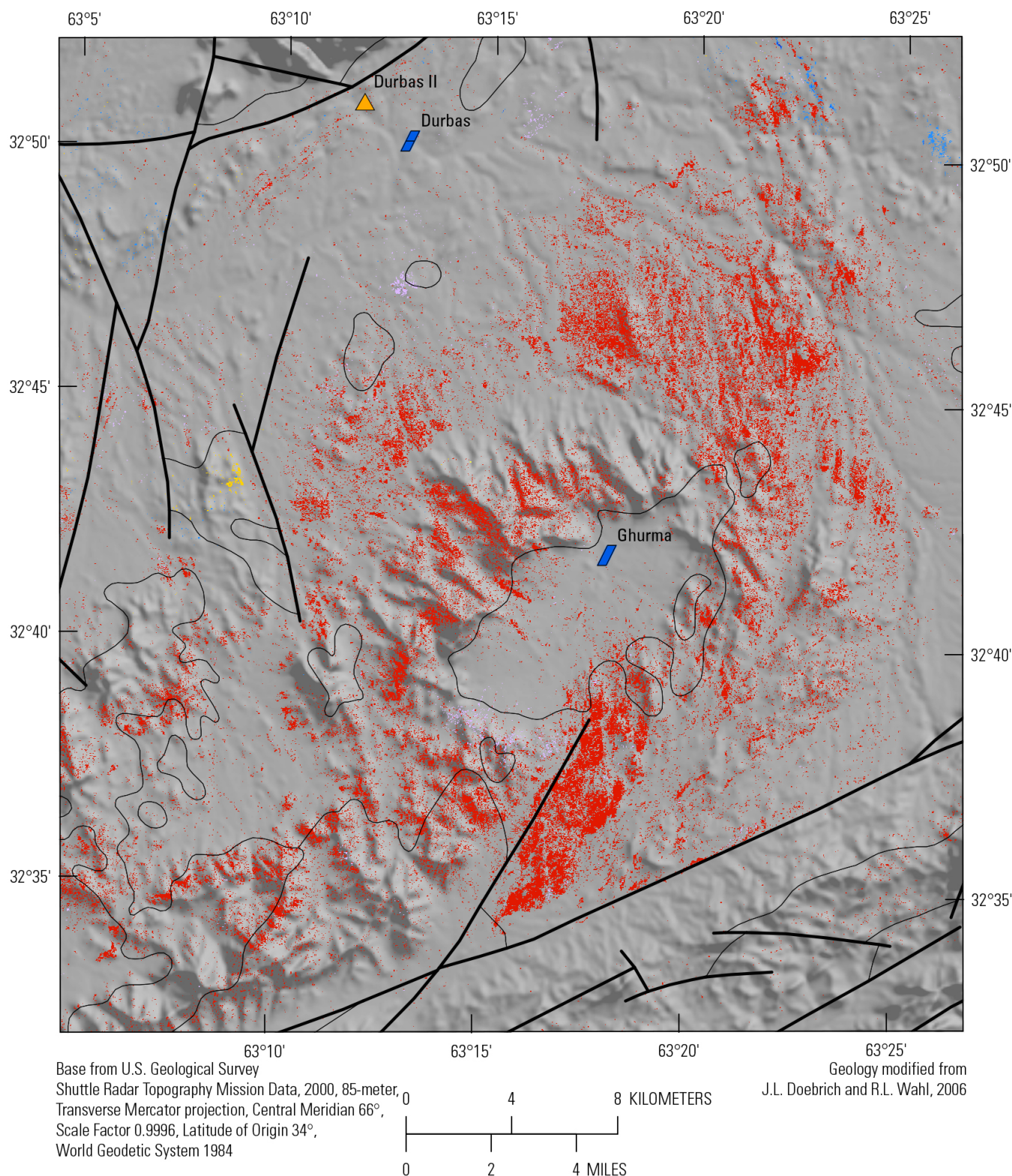

.

$2 \quad 4$ MLES

Figure 28. Map showing common alteration minerals derived from HyMap ${ }^{\mathrm{TM}}$ data in the Farah 1d subarea in Afghanistan (Kokaly and others, 2011, 2013). The detection of common alteration minerals is suggestive of possible past mineralization processes. 


\section{EXPLANATION}

Class name (pixel count)

Not classified $(1,822,644)$

Hematite, nanocrystalline $(89,099)$

Hematite, fine-grained (44)

Hematite, medium-grained (232)

Hematite, coarse-grained (306)

Iron hydroxide $(3,984)$

Goethite, fine-grained $(8,237)$

Goethite, medium-grained $(17,751)$

Goethite, coarse-grained $(23,221)$

Goethite and jarosite (80)

Jarosite (567)

$\mathrm{Fe}^{2+}$ type $2(38,489)$

$\mathrm{Fe}^{3+}$ type $1(279,252)$

$\mathrm{Fe}^{3+}$ type $2(1,065)$

$\mathrm{Fe}^{2+} \mathrm{Fe}^{3+}$ type $1(40,161)$

$\mathrm{Fe}^{2+} \mathrm{Fe}^{3+}$ type $2(86,681)$

$\mathrm{Fe}^{2+} \mathrm{Fe}^{3+}$ type $3(3,840)$

Epidote $(2,274)$

Ferrihydrite (83)

Green vegetation $(4,029)$

Dry vegetation $(8,658)$

Water $(1,168)$

Wet soils (1)

Faults
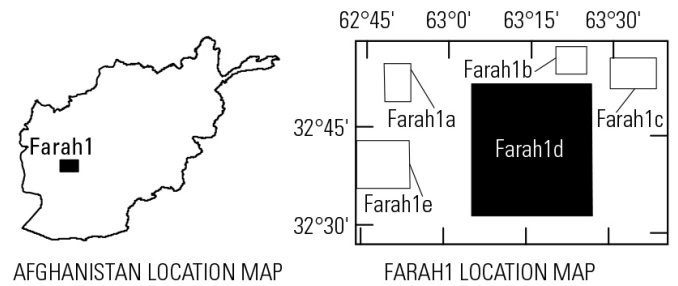

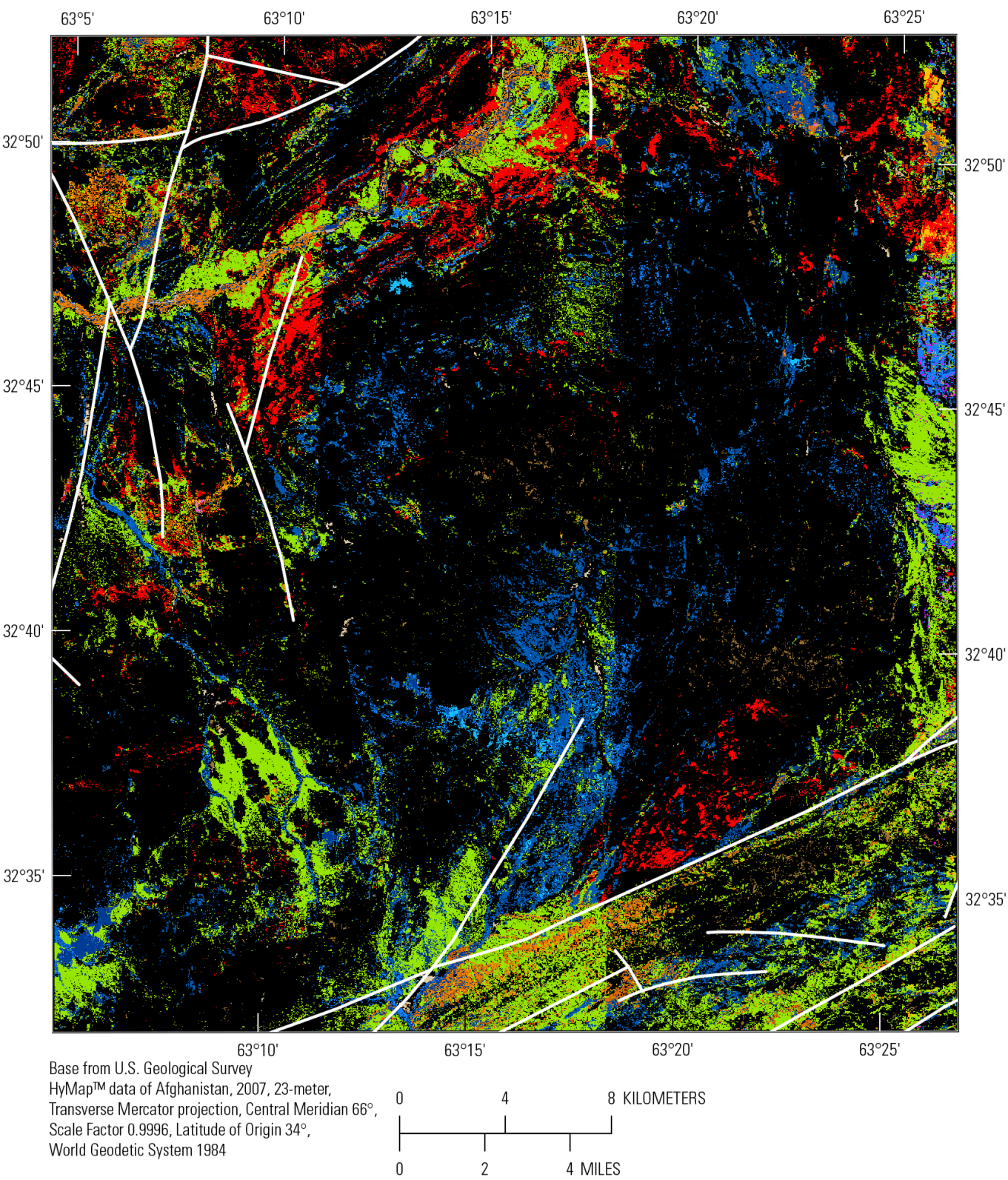

Figure 29. Map of iron-bearing minerals and other materials derived from HyMap ${ }^{\mathrm{TM}}$ data in the Farah $1 \mathrm{~d}$ subarea in Afghanistan (King and others, 2011b; Kokaly and others, 2013). 


\section{Farah 1e Subarea}

The dominant topographic feature in the Farah 1e subarea is a large, circular, topographic high (fig. 30). The subarea includes both stratified and intrusive rocks that include Early Cretaceous, late Quaternary ages (fig. 31). This is mapped as stratified Lower Cretaceous rocks (Abdullah and Chmyriov, 1977, Doebrich and Wahl, 2006) and is separated from Lower Cretaceous sedimentary rocks in the eastern half of the subarea by upper Quaternary detrital sedimentary rocks that include travertine. Wittekindt and Weippert (1973) map the Lower Cretaceous sedimentary units in the eastern half of the subarea (Abdullah and Chmyriov, 1977; Doebrich and Wahl, 2006) as Paleogene volcanic rocks.

The large circular feature is mapped as calcite in the HyMap ${ }^{\mathrm{TM}}$ data (fig. 32). Additional carbonate material is mapped in dispersed pixels and in smaller clumps across the subarea. Lesser amounts of iron-bearing carbonate, epidote or chlorite, muscovite, illite, and montmorillonite appear as dispersed occurrences and in well-defined, small clusters mainly in the Lower Cretaceous stratified rocks to the east of the circular feature. The Oligocene granite and granodiorite intrusive (fig. 31) is coincident with muscovite and muscovite-clay assemblages with lesser amounts of calcite, montmorillonite, and iron-bearing carbonate (fig. 32). Two spectrally distinct clusters of epidote or chlorite and iron-bearing carbonate are mapped in the southern part of the subarea in Lower Cretaceous stratified rocks. The Siab, Early Cretaceous, polymetallic $(\mathrm{Cu}, \mathrm{Pb}, \mathrm{Zn})$ vein mineral occurrence on the eastern side of the subarea (fig. 31) is associated with rocks mapped spectrally as calcite dominated.

Based on mineral distribution patterns, morphology and image analysis, the circular feature mapped as calcite may be related to volcanic activity. The feature resembles volcanic terrain in both the HyMap $^{\text {TM }}$ data, as well as the Landsat images (figs. 30 and 32). The calcite materials emanating from the topographic high in the center of the circular feature appear to overlay adjacent sediments, divert drainages, and interrupt sediment erosion patterns (fig. 30), thus suggesting that the feature is young relative to surrounding rocks. The German 1:500,000 geologic map (Wittekindt and Weippert, 1973) identifies the rocks in the northern part of the circular morphological feature as volcanic rocks of Paleogene age, although they are mapped as stratified mixed sedimentary rocks in other geologic maps (Abdullah and Chmyriov, 1977; Doebrich and Wahl, 2006).

The iron-bearing mineral map of the subarea le was collected under adverse light conditions and was not considered in this analysis. 
EXPLANATION

Faults

Lithologic contact
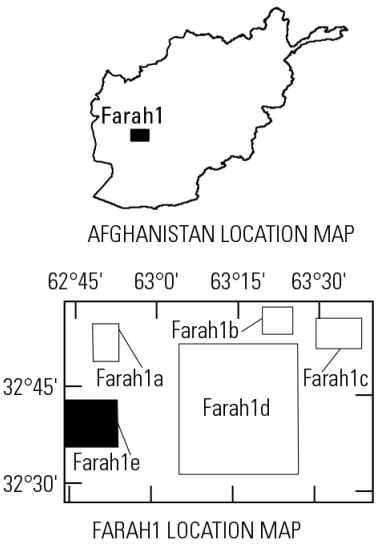

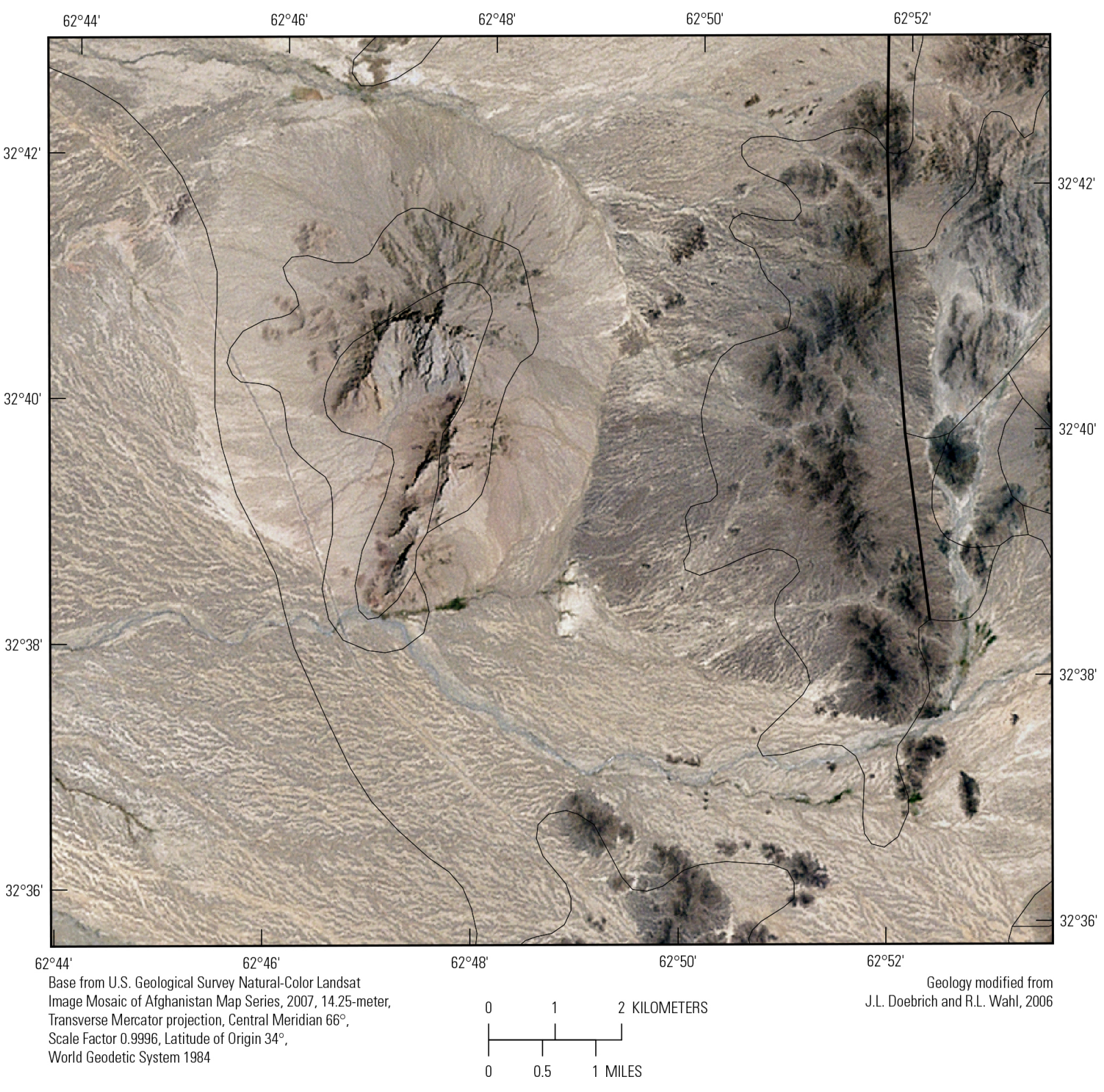

Figure 30. Contrast-enhanced stretch of the natural-color composite of Landsat Thematic Mapper bands from Davis (2007) of the Farah 1e subarea in Afghanistan. 


\section{EXPLANATION}

Stratified rocks

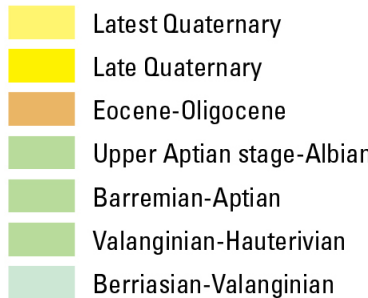

Intrusive rocks

Oligocen

Lithologic contact

- Faults

Non-fuel minerals

$\square$ polymetallic vein
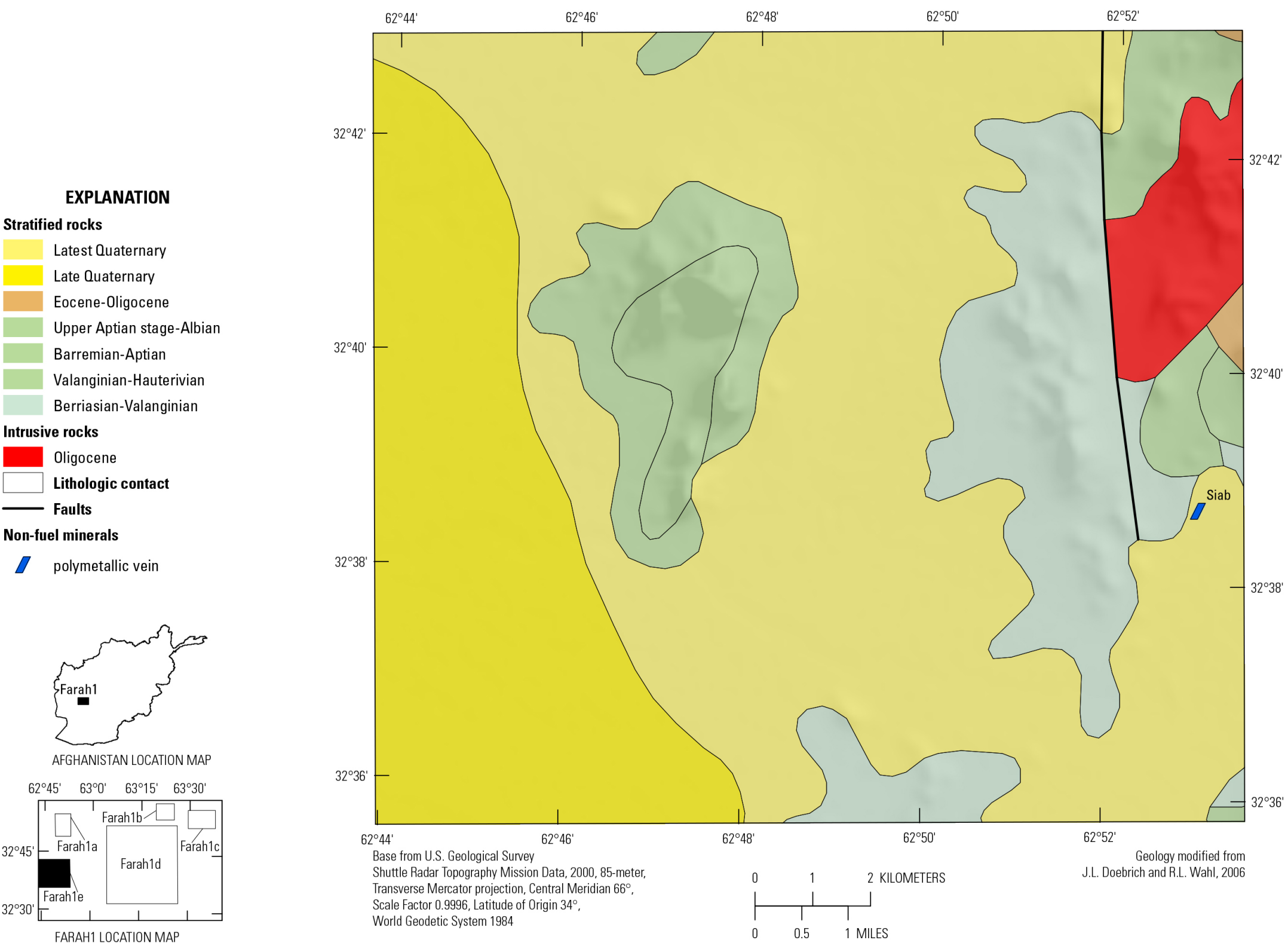

Figure 31. Geologic map and known mineral occurrence of the Farah 1e subarea in Afghanistan (Abdullah and Chmyriov, 1977; Abdullah and others, 1977; Doebrich and Wahl, 2006). 
EXPLANATION

\section{Class name (pixel count)}

Not classified (681)

Calcite, abundant (553)

Calcite $(184,480)$

Calcite and muscovite/clay $(1,485)$

Calcite and clay/muscovite $(151,676)$

Carbonate and clay/muscovite $(1,254)$

Carbonate, iron-bearing $(8,077)$

Dolomite (94)

Dolomite and clay/muscovite (156)

Epidote or chlorite $(15,196)$

Muscovite $(5,929)$

Illite $(19,324)$

Kaolinite and muscovite/clay/carbonate (62)

Montmorillonite $(1,169)$

Buddingtonite (3)

Serpentine (377)

Serpentine, or dolomite and calcite (93)

Tremolite or talc (1)

Green vegetation (52)

Dry vegetation (102)

Water (40)

Faults

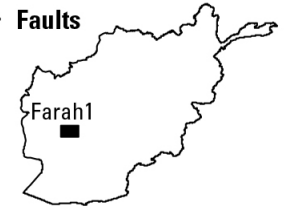

AFGHANISTAN LOCATION MAP
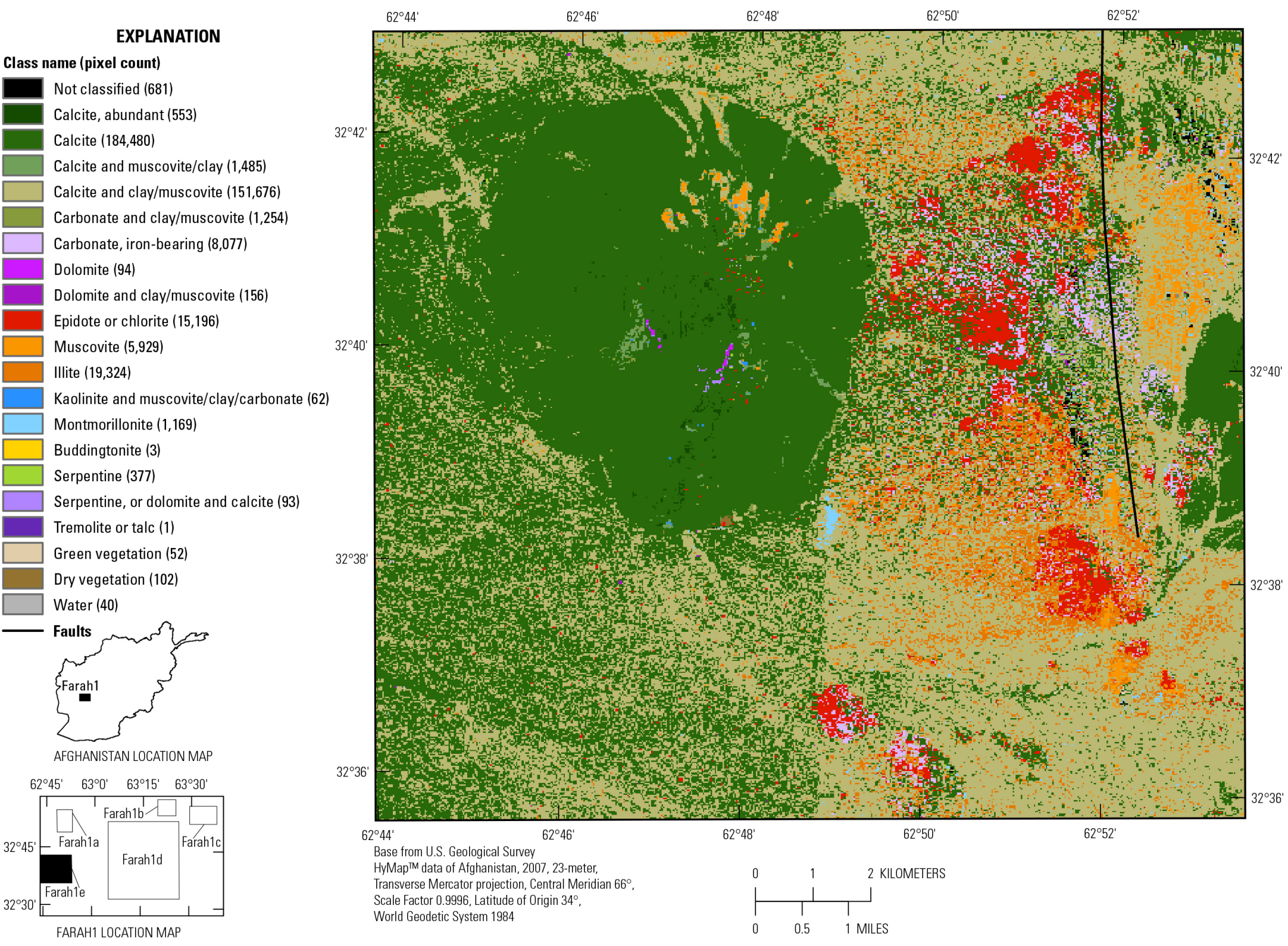

FARAH1 LOCATION MAP

Figure 32. Map of carbonates, phyllosilicates, sulfates, altered minerals, and other materials derived from HyMap ${ }^{\mathrm{TM}}$ data in the Farah 1e subarea in Afghanistan (Kokaly and others, 2011, 2013). 


\section{Summary of Potential Mineralization}

On the basis of the geology, imaging spectroscopy data, and the extent of the volcanic field, additional field verification of the Farah 1 area is warranted. The volcanic field crops out at the east end of a regionally extensive positive aeromagnetic feature, a probable magmatic-arc segment buried to the west of the volcanic field towards the town of Farah (Drenth, 2011). The preservation of some volcanic centers towards the northeast part of the field indicates the shallow extent of erosion, with the possibility of high-level hydrothermal activity, and known mineral occurrences containing $\mathrm{Cu}$ and $\mathrm{Zn}$ are scattered across the field. HyMap ${ }^{\mathrm{TM}}$ data delineate discrete areas of probable hydrothermal alteration including the occurrence of jarosite which suggests the likelihood of oxidized pyrite and other sulfides. Zoning patterns of mineral occurrences, interpretation of imaging data, and conflicting geologic maps reflect the mineralogical and structural complexity of the area. Future opportunities to collect field samples for additional analysis may identify specific targets for porphyry copper, polymetallic vein, and epithermal precious metal deposits.

\section{Ghazni 1 Area of Potential Mineralization}

The Ghazni 1 area, covering an area of $862 \mathrm{~km}^{2}$ (fig. 33), is located approximately $120 \mathrm{~km}$ southeast of Kabul in the northern part of Ghazni Province, Afghanistan, with a small section on the eastern edge in Wardak Province. The study area includes part of a north-south trending Quaternary volcanic field that transverses the Eocene-Oligocene Arghandab arc and part of a deformed tectonic unit that forms the back-arc region to the northwest of the volcano line. Montmorillonite and hydrous silica are the most common alteration phases mapped in the volcanic field, and occur in regions mapped as volcanic tuff and travertine (Abdullah and Chmyriov, 1977; Abdullah and others, 1977; Doebrich and Wahl, 2006). The alteration within the volcanic eruptive centers is consistent with high-level solfatara activity. 


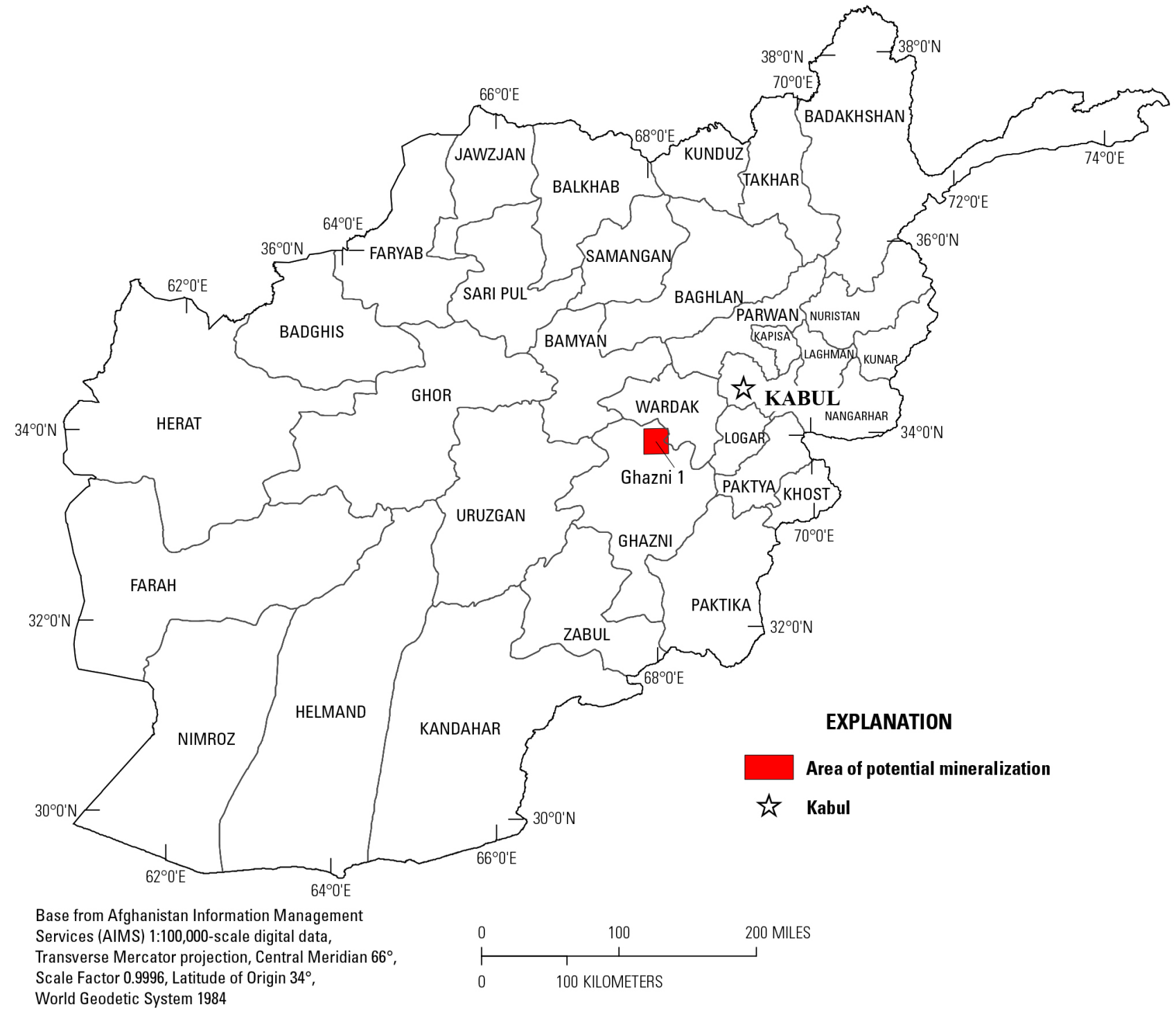

Figure 33. Location of the Ghazni 1 area in Afghanistan.

\section{Previous Work}

The most detailed, although scant, geologic information related to the Ghazni 1 area is provided by Abdullah and Chmyriov (1977), Abdullah and others (1977), and Doebrich and Wahl (2006).

Vikhter and others (1978) noted travertine occurrences around the perimeter of the Dasht-e Nawar salar, which may refer to tufa mounds. The northern tip of the Dasht-e Nawar salar is located approximately $12 \mathrm{~km}$ to the southwest of the Ghazni 1 area. Travertine tuffs are noted in the north and south parts of the volcanic field that also show hot spring activity with chloride-sulfate waters (Abdullah and Chmyriov, 1977). 


\section{Geology}

Pre-Tertiary rocks in the study area form a regionally extensive, northeast-trending, southwestplunging antiform transected by numerous post-folding northwest-striking, regionally extensive strikeslip faults. The pre-Tertiary rocks range from Ordovician through Permian and consist predominantly of siliciclastic rocks including sandstone, siltstone, and shale, but include limestone, dolomite, and marl (Doebrich and Wahl, 2006). There are no known mineral occurrences in the Paleozoic rocks within the study area, but Abdullah and Chmyriov (1977) show aluminum deposits southeast of the study area boundary. In addition, Russian stream sediment sampling to the northeast of the study area found anomalous lead and tungsten in the Paleozoic sedimentary rocks within the regional-scale antiform (Abdullah and Chmyriov, 1977).

\section{Mineralization}

A Quaternary volcanic field made up of mafic- to intermediate-composition rocks trends northsouth and makes up the western part of the study area. Lithologies include andesite, dacite tuff, and welded ash flows. Erosion trends and a north-south elongate salar suggest that the volcanic field is localized within a rift basin. Remnant volcanic centers crop out on the outer topographic walls of the rift and form linear clusters within the rift. Landsat TM imagery shows the volcanic edifices to be breached by erosion and, sector collapse may have locally exposed zones of hydrothermal alteration in the volcanic cores (fig. 34). Doebrich and Wahl (2006) show extensive areas of travertine in the northern part of the study area indicative of bicarbonate hot-spring activity, and Abdullah and Chmyriov, (1977) show the occurrence of bicarbonate spring waters as well as a siliceous spring occurrence along the edge of a travertine field. These springs are interpreted as modern equivalents of the springs that deposited travertine and silica with the siliceous spring water suggesting that higher temperature, near-neutral $\mathrm{pH}$ geothermal flow was once active and may continue to be active.

Montmorillonite and hydrous silica are the most common materials mapped in the predominantly north-south Quaternary volcanic field which defines the Ghazni 1 study area (figs. 35 and 36). Intermediate composition, tuffaceous volcanic rocks and travertine-rich terrain (Abdullah and Chmyriov, 1977; Abdullah and others, 1977; Doebrich and Wahl, 2006) are primarily mapped as montmorillonite that is intermixed with relatively minor amounts of dolomite, calcite, and kaolinite that also contains other phyllosilicate mixtures (fig. 36) (Kokaly and others, 2011, 2013). Hydrous silica is mapped using the HyMap ${ }^{\mathrm{TM}}$ data in abundances nearly equal to montmorillonite. The proximity of hydrous silica to two volcanic centers near $67^{\circ} 54^{\prime} 50.966^{\prime \prime} \mathrm{E}, 33^{\circ} 54^{\prime} 41^{\prime \prime} \mathrm{N}$ and $67^{\circ} 55^{\prime} 35.32^{\prime \prime} \mathrm{E}, 33^{\circ} 55^{\prime}$ 29.26"N (Abdullah and Chmyriov, 1977), suggests the presence of siliceous sinter deposits or their weathering products (fig. 36). 
EXPLANATION

Lithologic contact

- Faults

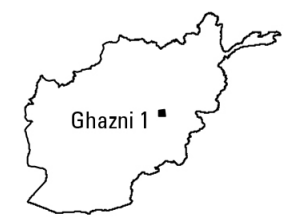

AFGHANISTAN LOCATION MAP

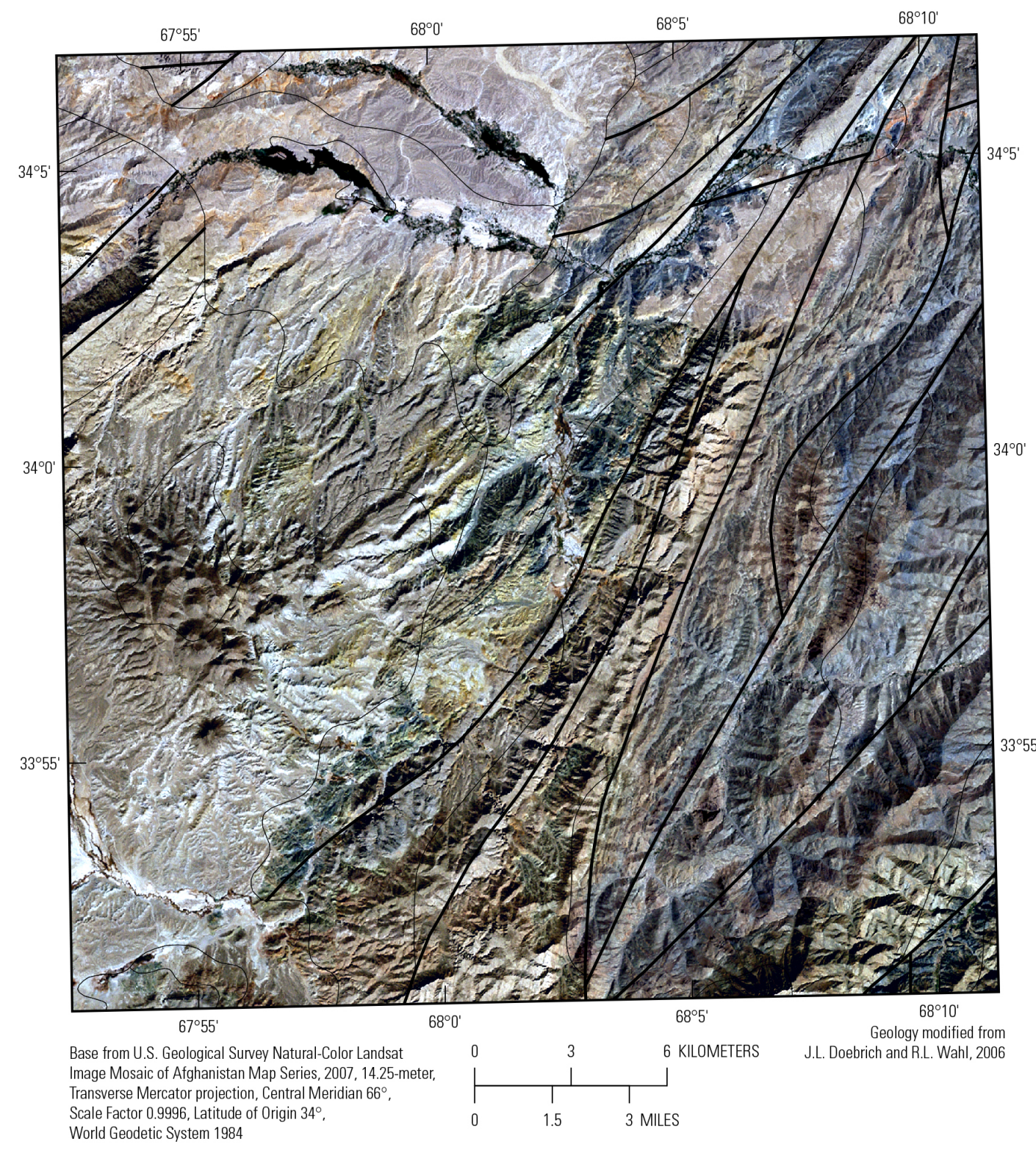

Figure 34. Contrast-enhanced stretch of the natural-color composite of Landsat Thematic Mapper bands from Davis (2007) of the Ghazni 1 area in Afghanistan. 


\section{EXPLANATION}

Stratified rocks

Late Quaternary

Middle Quaternary

Early Quaternary

Miocene. Undifferentiated

Middle Jurassic-Late Jurassic

Rhaetian-Early Jurassic

Carnian-Norian

Middle Triassic

Early Triassic

Late Permian

Carboniferous-Early Permian

Late Devonian

Early Devonian-Middle Devonian

Silurian

Ordovician

Volcanic field with travertines

Volcanic field

Lake

Lithologic contact

- Faults

文 Volcano

Mineral waters

(-) Carbonated

- Siliceous

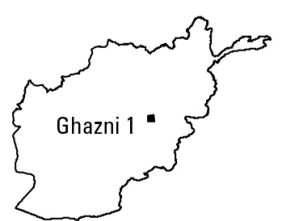

AFGHANISTAN LOCATION MAP

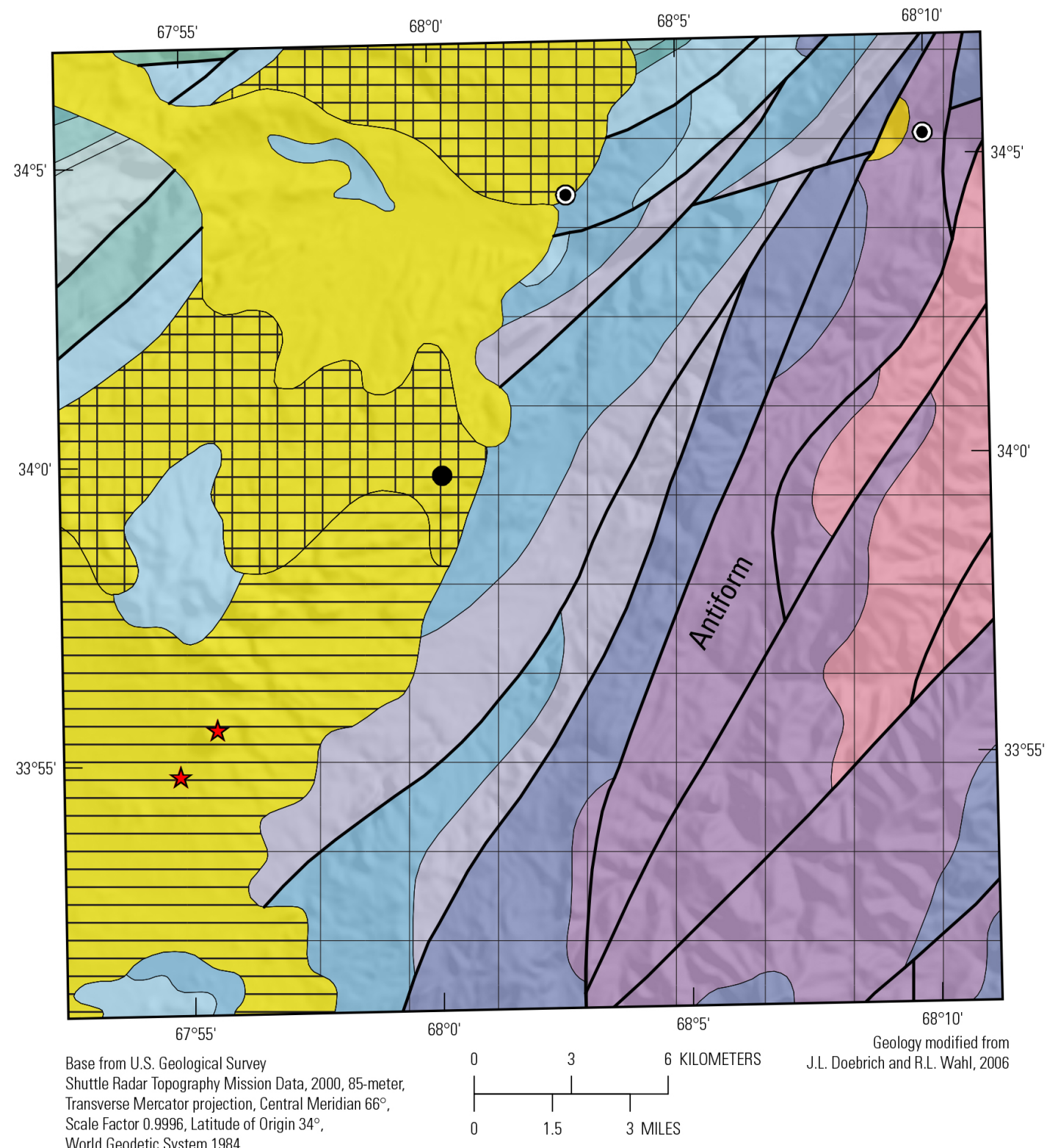

Scale Factor 09996 , Latitude of Origin $34^{\circ}$

igure 35. Geologic map and known mineral occurrences in the Ghazni 1 area in Afghanistan (Abdullah and Chmyriov, 1977; Abdullah and others, 1977; Doebrich and Wahl, 2006). 


\section{EXPLANATION}

Class name (pixel count)

Not classified $(27,155)$

Calcite, abundant $(5,997)$

Calcite $(615,567)$

Calcite and muscovite/clay $(123,513)$

Calcite and clay/muscovite $(262,743)$

Carbonate and clay/muscovite $(17,025)$

Dolomite $(30,163)$

Dolomite and clay/muscovite $(3,072$

Epidote or chlorite $(884)$

Muscovite $(181,257)$

Illite $(35,769)$

Kaolinite (alunite, pyrophyllite, or dickite may be

present) $(2,526$

Kaolinite (62)

Kaolinite and muscovite/clay/carbonate $(8,046)$

Montmorillonite $(117,525)$

Alunite (2)

Pyrophyllite (alunite or kaolinite may be present) (133)

Jarosite (9)

Serpentine $(8,960)$

Serpentine, or dolomite and calcite $(39,154)$

Tremolite or talc (19)

Hydrated silica $(23,377)$

Gypsum (574)

Green vegetation $(46,911)$

Dry vegetation $(61,369)$

Water (166)

Wet soils (244)

Cloud or cloud shadow $(17,572)$

Faults

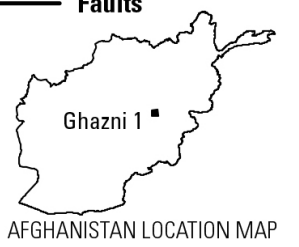

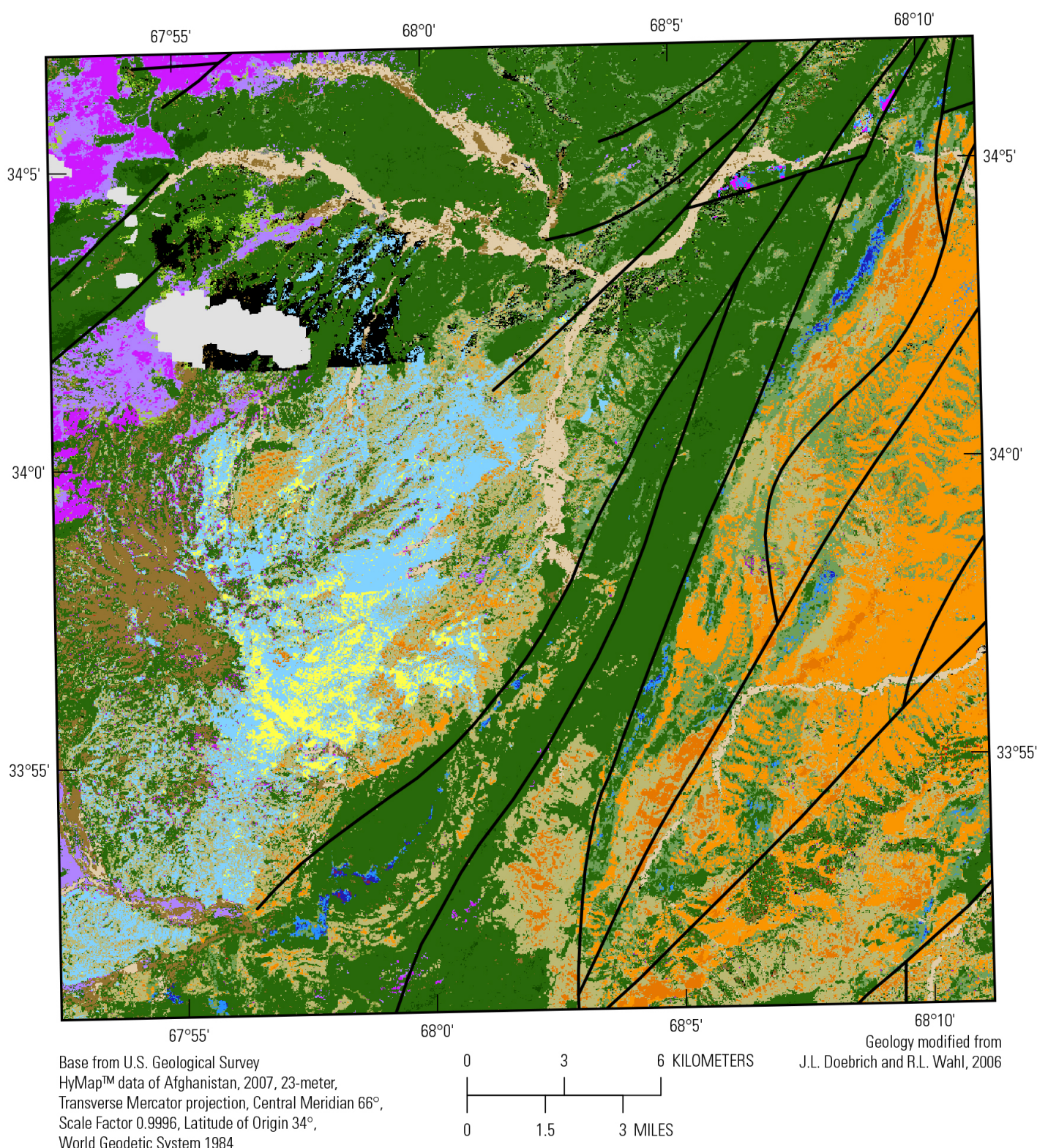

, Latitude of Origin $34^{\circ}$

Figure 36. Map of carbonates, phyllosilicates, sulfates, altered minerals, and other materials derived from HyMap ${ }^{\mathrm{TM}}$ data in the Ghazni 1 area in Afghanistan (Kokaly and others, 2011, 2013). 


\section{Imaging Spectroscopy Data}

Distribution patterns of the alteration minerals and gradational contacts between the surrounding country rocks (Abdullah and Chmyriov, 1977; Abdullah and others, 1977; Doebrich and Wahl, 2006) support the concept that the surficial minerals were constituents of an ash fall tuff, rather than mechanically transported clastic material as a flow or from products of groundwater alteration (Papke, 1969). Figure 36 shows that mixtures of montmorillonite/hydrous silica material appear to overlay Devonian sandstone, siltstone and shale and Carboniferous-Lower Permian clastic/volcanic rocks on the eastern margin of the antiform (fig. 35). The combined presence of hydrous silica and montmorillonite near the volcanic edifices and the genetically associated tuffs are suggestive of different degrees/stages of mineral weathering in ash fall beds. Montmorillonite represents near complete devitrification of the glassy volcanic ash and the hydrous silica indicates the presence of less-weathered volcanic glass.

The Permian-Jurassic sequences on either side of the western margin of the volcanic field are characterized by dolomite, calcite and muscovite/illite in the Ordovician-Permian clastic formations on the eastern flank (fig. 35). Pyrophyllite and kaolinite mineral assemblages are mapped along the contact zones between the Silurian-Devonian and Silurian-Devonian and Permian Carboniferous clastic rocks on the eastern limb (fig. 35). The linear nature of the mapped occurrence, the paucity of other mineral assemblages suggestive of hydrothermal activity, and the clastic nature of the rocks in the Ghazni 1 area, would suggest that pyrophyllite probably resulted from digenesis and prograde regional metamorphism (Henderson, 1970).

Small northeast-striking linear occurrences of gypsum, kaolinite, and clay/carbonate mixtures in the northeast part of the study area (fig. 36) are potential indicators of secondary alteration, likely associated with fluid movement at lithological contacts along faults.

Figure 37 shows the iron-bearing secondary minerals detected and mapped from the HyMap ${ }^{\mathrm{TM}}$ data, but these minerals have limited spectral expression in the Quaternary volcanic field. This is consistent with the postulate that the secondary minerals in the field have little iron in the mineral structures and (or) weathering of iron-bearing minerals is limited. Areas mapped as goethite, $\mathrm{Fe}^{2+}$ type 2, and $\mathrm{Fe}^{3+}$ type 1 (fig. 37) do not have an association with montmorillonite or hydrous silica (fig. 36) and likely represent outlier fragments of country rock.

In contrast to the alteration assemblage observed in the volcanic field, older rock units in the northwest-southeast folded sequences on either side contain abundant hematitic, goethitic, various

$\mathrm{Fe}^{2+} \mathrm{Fe}^{3+}$, and $\mathrm{Fe}-$ hydroxide assemblages particularly associated with Ordovician-Silurian rocks (figs. 35 and 37). 


\section{EXPLANATION}

Class name (pixel count)

Not classified $(1,021,939)$

Hematite, nanocrystalline $(72,032$

Hematite, fine-grained (1)

Hematite, medium-grained (23)

Iron hydroxide $(18,334)$

Goethite, fine-grained $(151,135)$

Goethite, medium-grained $(174,117)$

Goethite, coarse-grained $(8,047)$

Goethite and jarosite (2)

Jarosite (4)

$\mathrm{Fe}^{2+}$ type $2(4,938$

$\mathrm{Fe}^{3+}$ type $1(7,807)$

$\mathrm{Fe}^{2+} \mathrm{Fe}^{3+}$ type $1(29,860)$

$\mathrm{Fe}^{2+} \mathrm{Fe}^{3+}$ type $2(20,234)$

Epidote (609)

Maghemite (36)

Green vegetation $(55,635)$

Dry vegetation $(47,072$

Water (173)

Wet soils (224)

Cloud or cloud shadow $(17,572)$

Faults

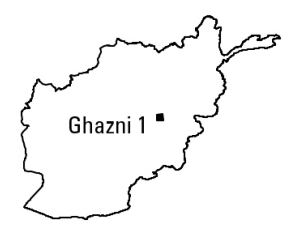

AFGHANISTAN LOCATION MAP

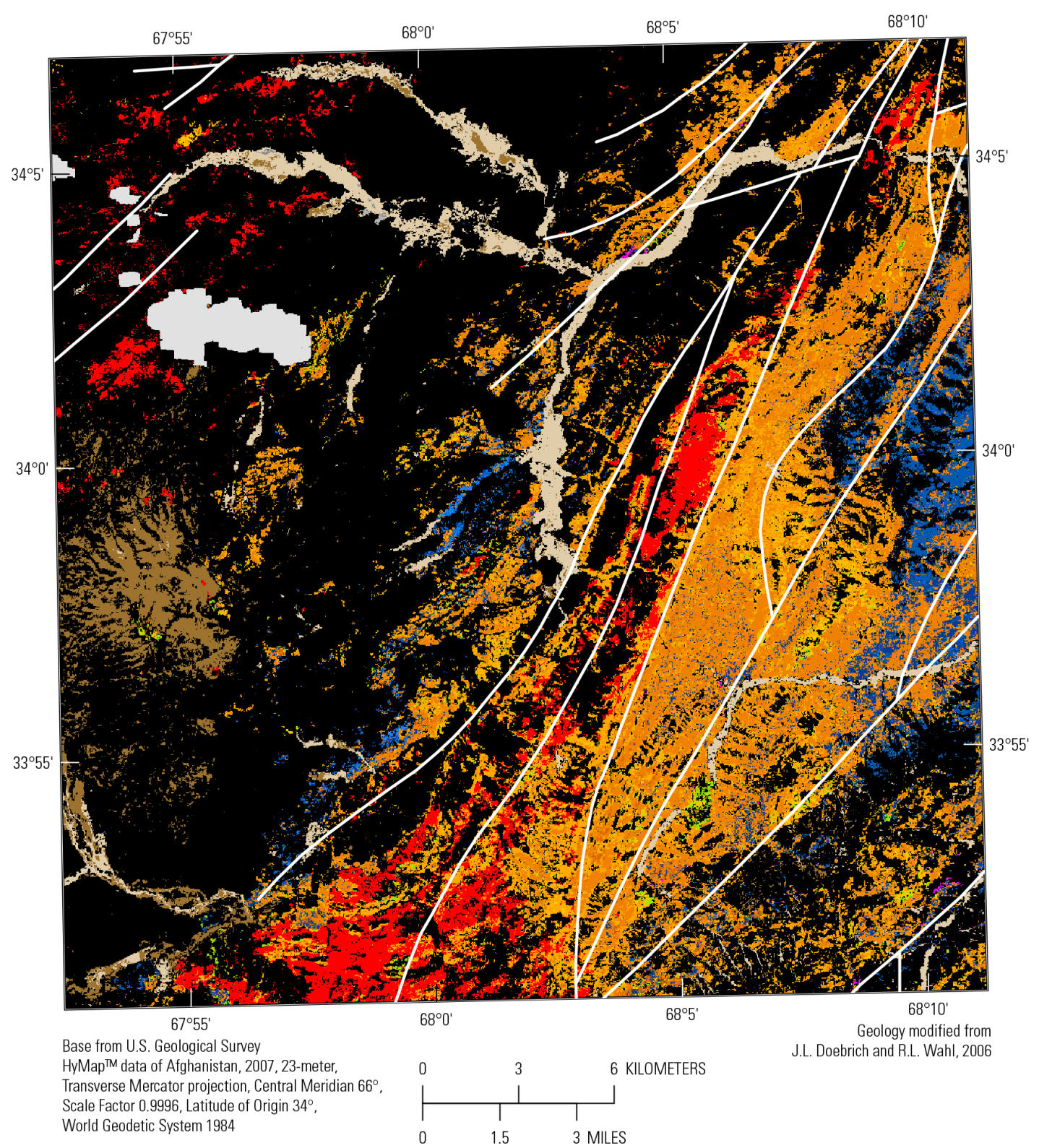

Figure 37. Map of iron-bearing minerals and other materials derived from HyMap ${ }^{\mathrm{TM}}$ data in the Ghazni 1 area in Afghanistan (King and others, 2011b; Kokaly and others, 2013). 


\section{Summary of Potential Mineralization}

Based on the distribution of alteration minerals the most significant potential in the study area is associated with the Quaternary volcanic rocks within the rift basin, although some potential exists in the Paleozoic rocks for industrial clay and aluminum.

The high level of alteration within the volcanic centers perhaps related to solatara-type activity and associated with thermal waters in the rift, suggests that the potential is greatest for mercury, sulfur, and precious metal deposits, by analogy to other active volcanoes. In the latter, high-temperature deposits related to magmatic-gas flow include sulfur and mercury deposition in the fumarolic discharge zones and high-sulfidation gold-copper deposits below the venting fumaroles. Porphyry copper deposits are also surmised to occur in these environments at depths of 1.5 to $4 \mathrm{~km}$ (Henley and Berger, 2013). Spectral signatures of hydrous silica most likely indicate the presence of sinter deposits peripheral to the centers of volcanism. By analogy to other modern geothermal systems, the sinter probably was deposited by near-neutral $\mathrm{pH}$ fluids in association with clay and mercury. Such systems may deposit gold, arsenic, and antimony within the upflow zones beneath the discharging vents (Henley and Ellis, 1983).

\section{Ghazni 2 Area}

The Ghazni 2 area, approximately $496 \mathrm{~km}^{2}$, is in a mountainous region in central Ghazni Province, southeast Afghanistan (fig. 38). It lies within a Quaternary volcanic-sedimentary rift basin that crosscuts the northeast-trending Eocene-Oligocene Arghandab magmatic arc west of the Chaman fault; the suture zone between the Central Mountains tectonic domain to the northwest and the Belutchan domain to the southeast (Abdullah and Chymriov, 1977; Wheeler and others, 2005; Doebrich and Wahl, 2006; Ruleman and others, 2007). Mineral resource potential in the study area resides predominantly in high-level hot springs and fumarolic activity in and around the Quaternary volcanic edifices (Abdullah and Chymriov, 1977). 


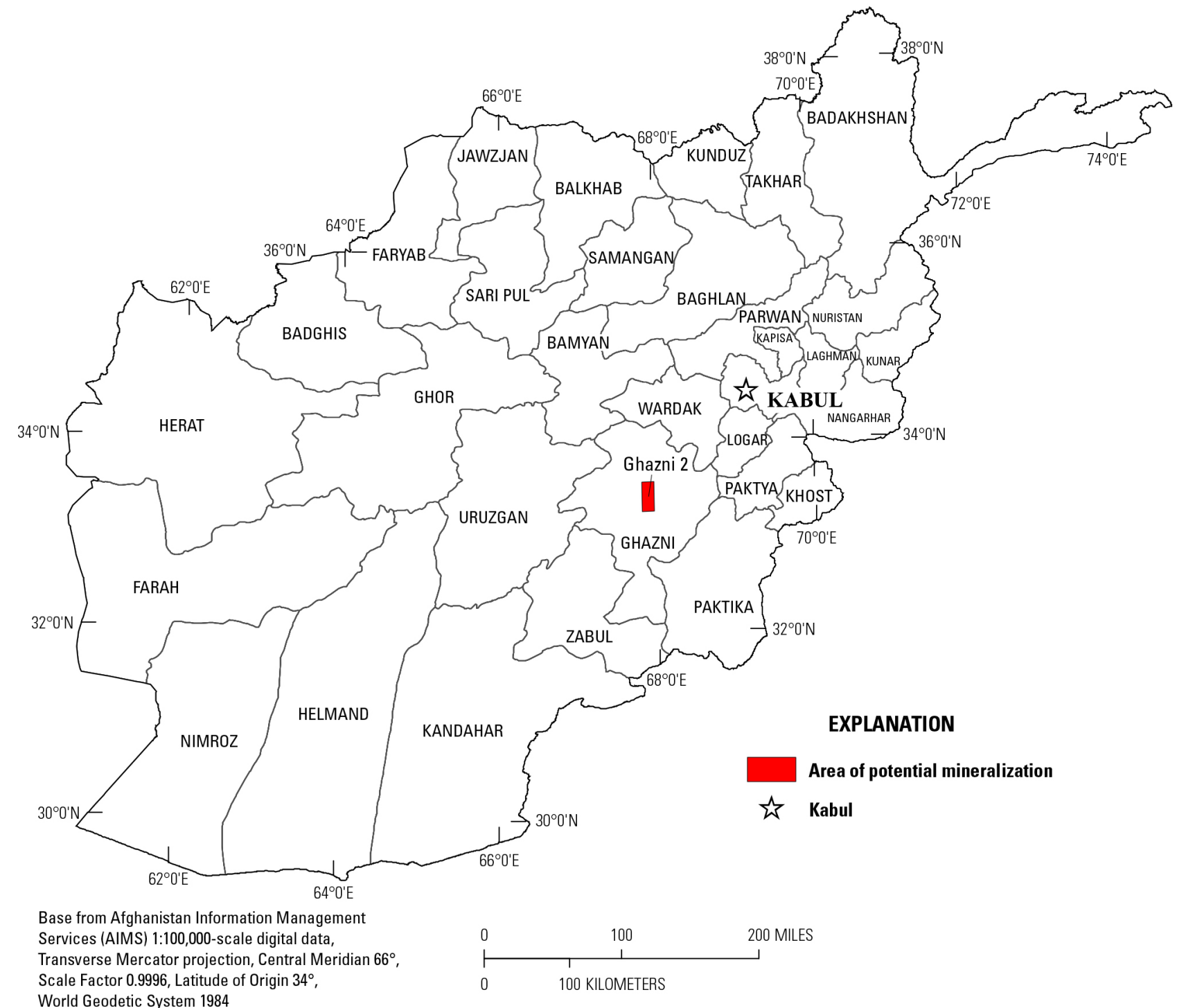

Figure 38. Location of the Ghazni 2 area in Afghanistan.

\section{Geologic Framework}

The oldest rocks in the study area occur at its northern end, and consist of Upper Devonian sandstone, siltstone, and limestone in contact with lower Quaternary volcanic and sedimentary rocks (fig. 39). The volcanic rocks are predominantly andesite, dacite tuff, and ash-flow tuff. The rift basin (Vikhter and others, 1978) sedimentary rocks consist of conglomerate, gravel, sand, siltstone, breccia, limestone, gypsum, and clay (Doebrich and Wahl, 2006).

Deep erosional features are clearly visible as radial drainages in the southern and eastern regions of the area (fig. 40). Bright surface material in the Dasht-e Nawer salar is also visible in the northwest corner of the study area (fig. 40). 

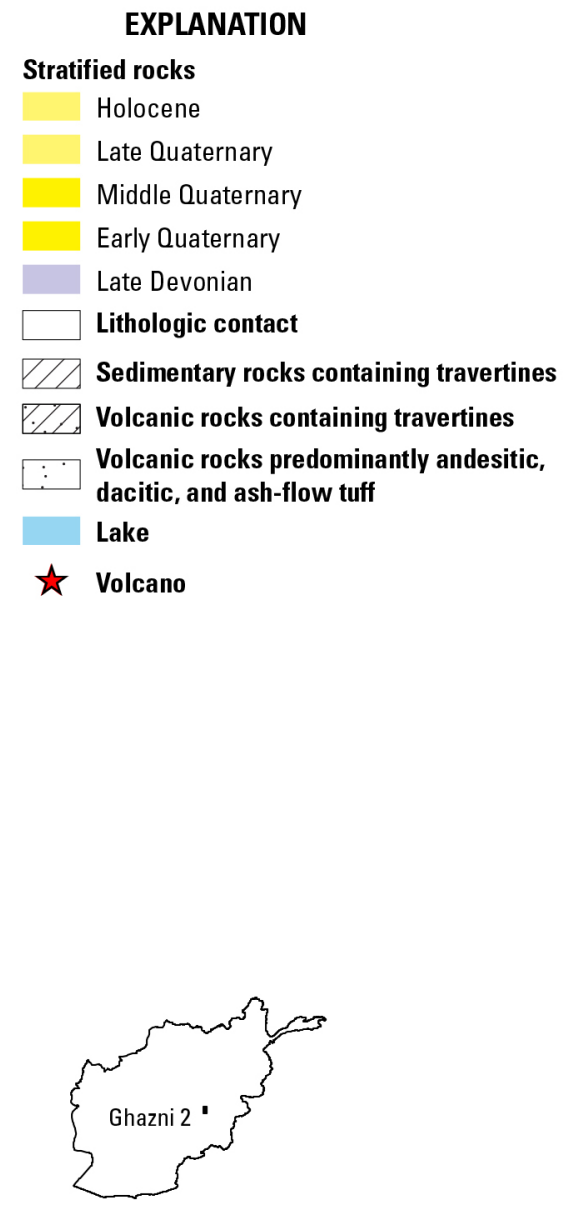

AFGHANISTAN LOCATION MAP

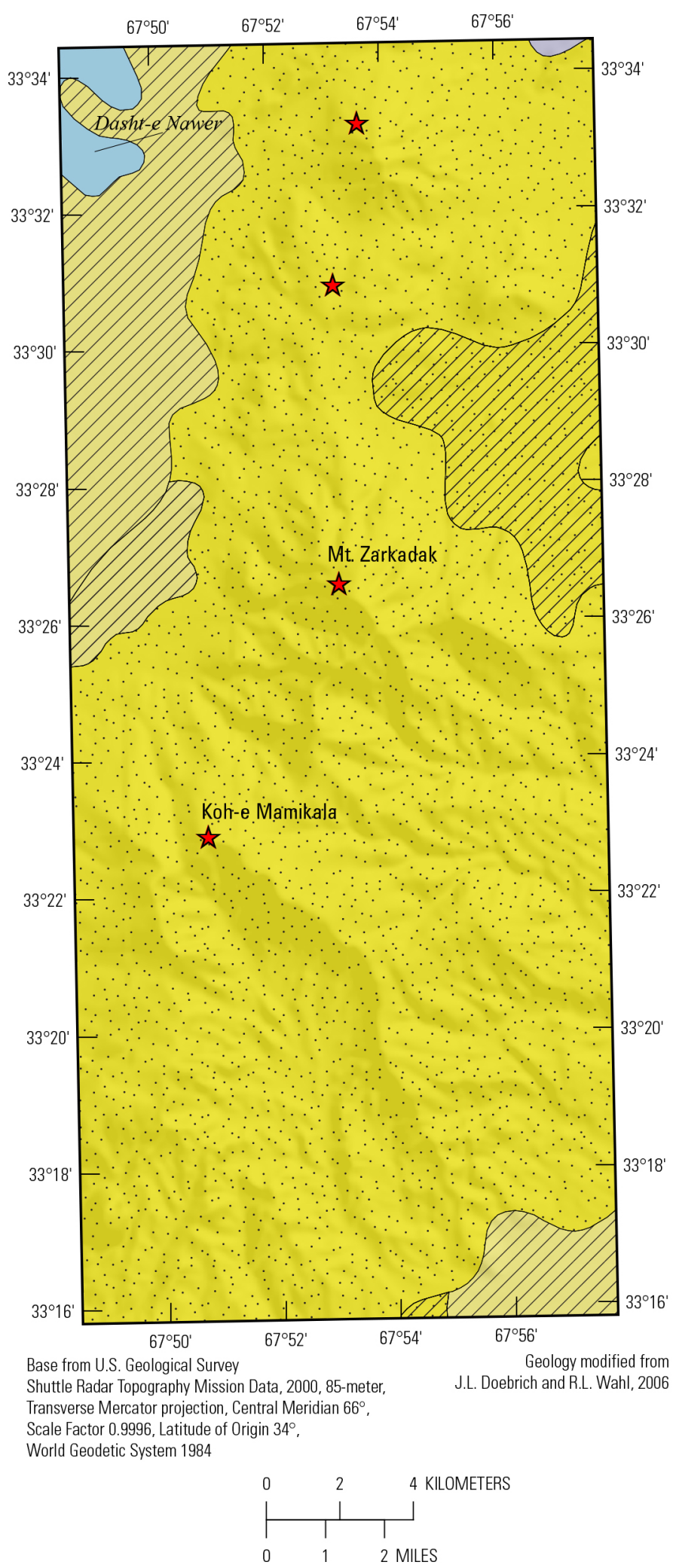

Figure 39. Geologic map and known mineral occurrences in the Ghazni 2 area in Afghanistan (Abdullah and Chmyriov, 1977; Abdullah and others, 1977; Doebrich and Wahl, 2006). 


\section{EXPLANATION}

Lithologic contact

ל̌ Volcano

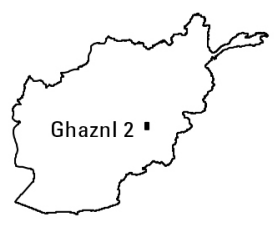

AFGHANISTAN LOCATION MAP

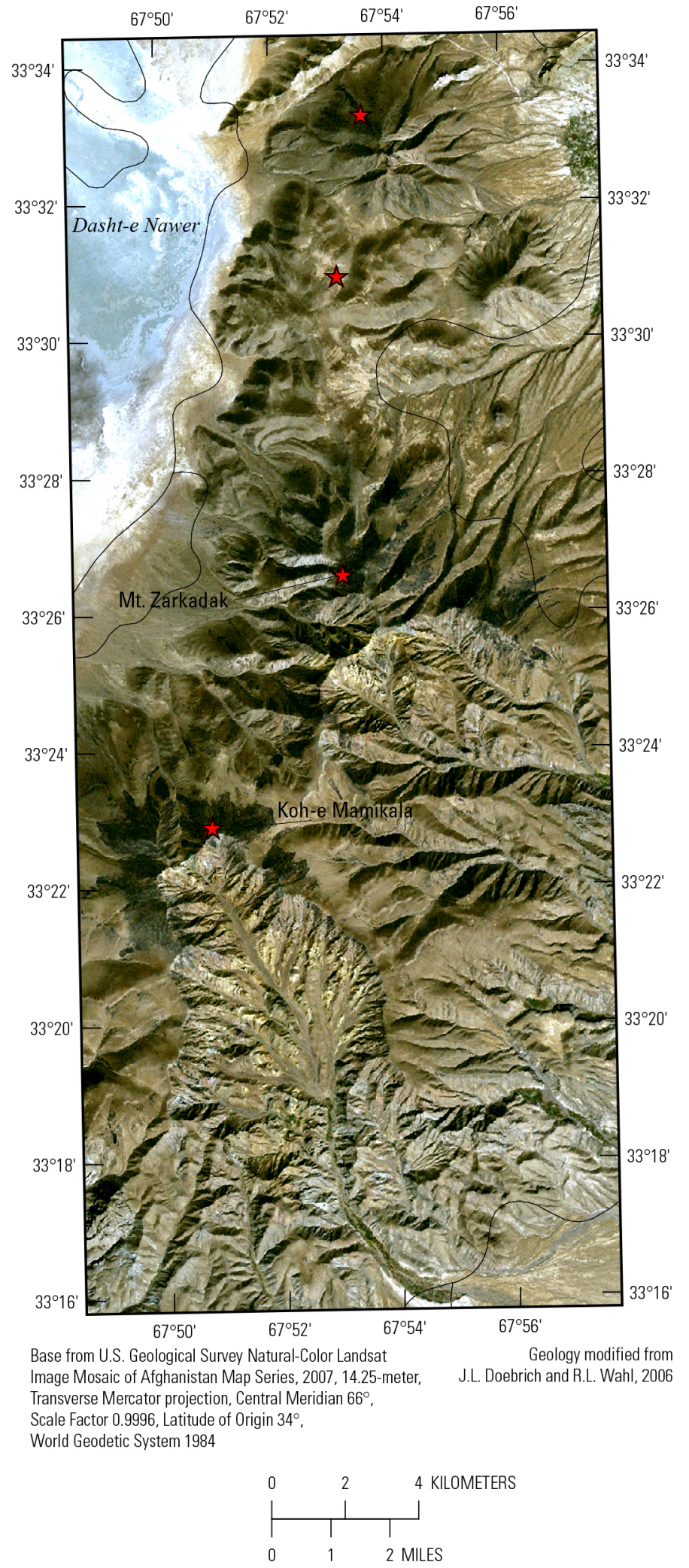

Figure 40. Contrast-enhanced stretch of the natural-color composite of Landsat Thematic Mapper bands from Davis (2007) of the Ghazni 2 area in Afghanistan. 


\section{EXPLANATION}

Class name (pixel count)

Not classified $(10,255)$

Calcite, abundant (452)

Calcite $(356,111)$

Calcite and muscovite/clay $(9,206)$

Calcite and clay/muscovite $(68,877)$

Carbonate and clay/muscovite $(2,445)$

Dolomite $(12,242)$

Dolomite and clay/muscovite $(10,670)$

Epidote or chlorite $(2,276)$

Muscovite $(5,530)$

Illite $(7,586)$

Kaolinite (alunite, pyrophyllite, or dickite may be present) $(4,648)$

Kaolinite (746)

Kaolinite and muscovite/clay/carbonate $(2,312)$

Montmorillonite $(64,750)$

Alunite $(1,001)$

Alunite and kaolinite (474)

Pyrophyllite (alunite or kaolinite may be present) (3) Jarosite (51)

Buddingtonite $(1,161)$

Serpentine $(18,614)$

Serpentine, or dolomite and calcite $(8,174)$

Tremolite or talc (2)

Hydrated silica $(1,083)$

Gypsum (1)

Green vegetation $(19,996)$

Dry vegetation $(330,022)$

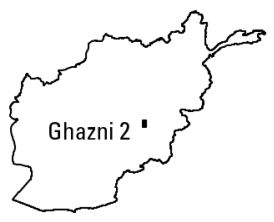

AFGHANISTAN LOCATION MAP

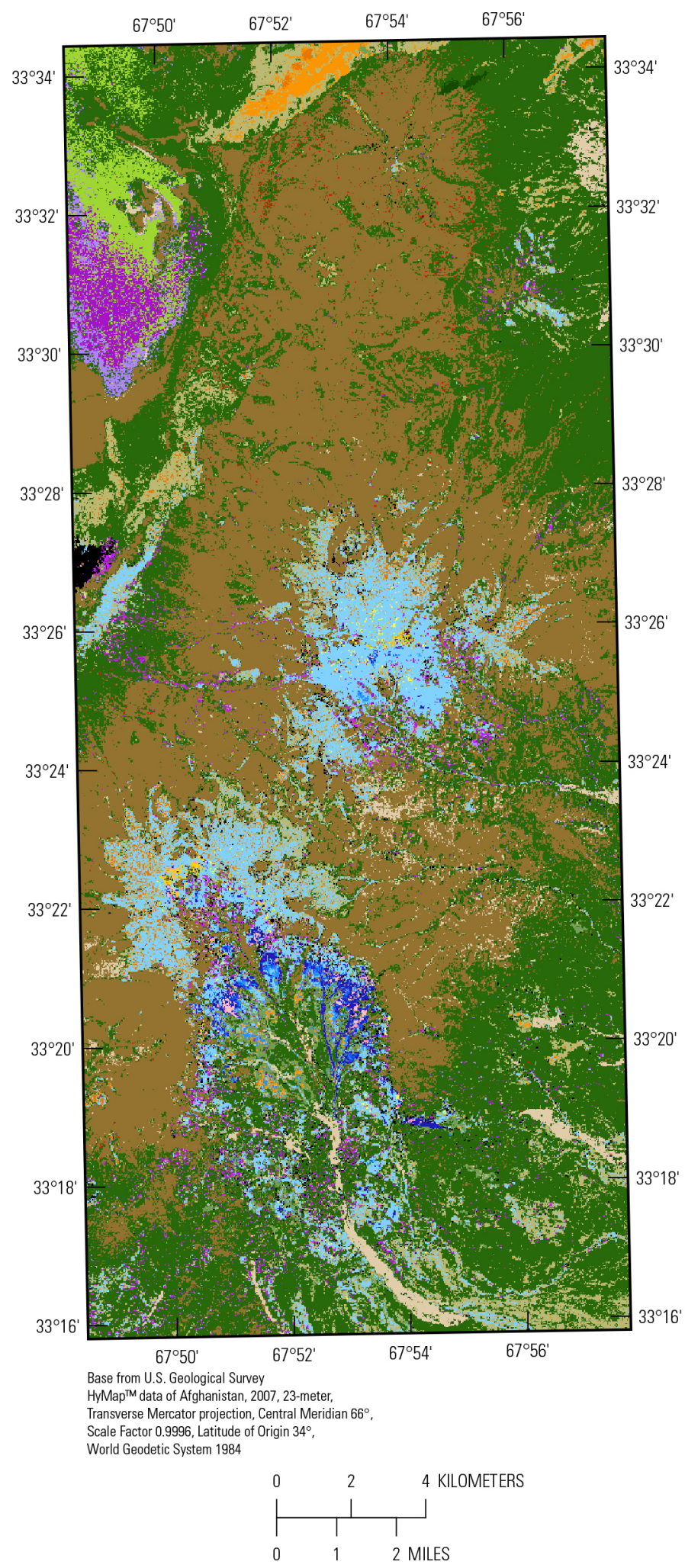

HyMap'M data of Afghanistan, 2007, 23-meter

Transverse Mercator projection, Central Meridian 66.

Scale Factor 0.9996, Latitude of Origin $34^{\circ}$

Figure 41. Map of carbonates, phyllosilicates, sulfates, altered minerals, and other materials derived from HyMap $^{\text {TM }}$ data in the Ghazni 2 area in Afghanistan (Kokaly and others, 2011, 2013). 


\section{EXPLANATION}

Class name (pixel count)

Not classified $(434,383)$

Hematite, nanocrystalline $(25,739)$

Hematite, medium-grained (70)

Hematite, coarse-grained (12)

Iron hydroxide $(14,165)$

Goethite, fine-grained $(60,401)$

Goethite, coarse-grained $(5,848)$

Goethite and jarosite (8)

Jarosite (264)

$\mathrm{Fe}^{2+}$ type $2(6,603)$

$\mathrm{Fe}^{3+}$ type $1(4,988)$

$\mathrm{Fe}^{3+}$ type 2 (569)

$\mathrm{Fe}^{2+} \mathrm{Fe}^{3+}$ type $1(1,403)$

$\mathrm{Fe}^{2+} \mathrm{Fe}^{3+}$ type $2(385)$

$\mathrm{Fe}^{2+} \mathrm{Fe}^{3+}$ type $3(14,233)$

Epidote (1,392)

Maghemite (90)

Green vegetation $(45,096)$

Dry vegetation $(320,115)$

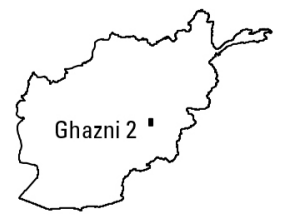

AFGHANISTAN LOCATION MAP
Goethite, medium-grained $(2,924)$

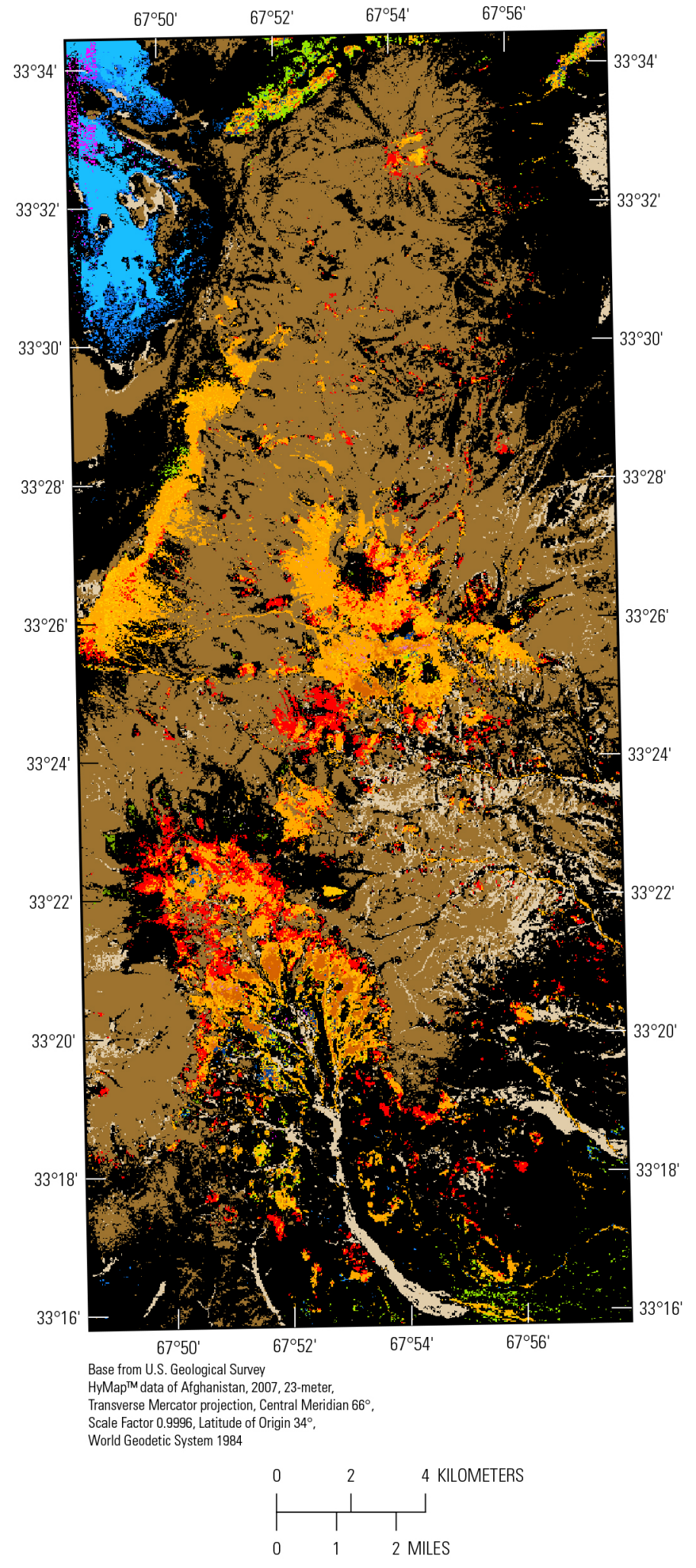

Figure 42. Map of iron-bearing minerals and other materials derived from HyMap ${ }^{\text {TM }}$ data in the Ghazni 2 area in Afghanistan (King and others, 2011b; Kokaly and others, 2013). 
In the southern part of the area, Pliocene-Quaternary lavas and dacitic, andesite-dacitic, and andesitic tuff (Vikhter and others, 1978) are associated with the two volcanoes, Koh-e Mamikala and Mt. Zarkadak (figs. 39 and 40). Significant areas of alunite group minerals and kaolinites with clustered occurrences of buddingtonite and hydrated silica are spatially associated with these volcanoes (fig. 41). In volcanic edifices, these minerals are commonly the result of hydrothermal alteration related to fumarolic venting of volcanic gases (for example, MacDonald, 1944) and may indicate a related potential for shallow mineralization or in the subsurface. Hydrothermal alteration related to solfataric venting of $\mathrm{H}_{2} \mathrm{O}, \mathrm{SO}_{2}, \mathrm{H}_{2} \mathrm{~S}$, and $\mathrm{CO}_{2}$ gases commonly forms alunite, silica, and kaolinite minerals along with native sulfur.

The alunite and kaolinite minerals group mineral assemblage are the uppermost units mapped in Koh-e Mamikala, a breached volcano near $33^{\circ} 22^{\prime} 54^{\prime \prime N}, 67^{\circ} 50^{\prime} 48^{\prime \prime} \mathrm{E}$, and exposed in the face of a ruptured wall (figs. 41, 43, and 44). The alunite minerals form a discrete layer in the exposed face of the breached wall, and are mapped near the top of the volcano and the lower reaches of the drainage. Jarosite, hydrous silica, and buddingtonite were sparingly recognized spectrally in the drainage to the southeast side of the ruptured wall (figs. 41, 43, and 44). 


\section{EXPLANATION}

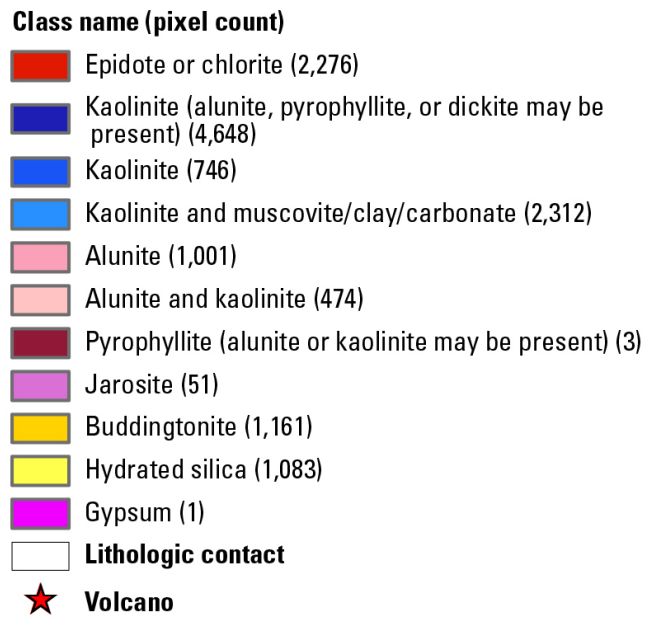

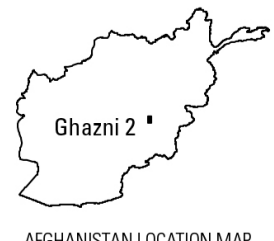

AFGHANISTAN LOCATION MAP

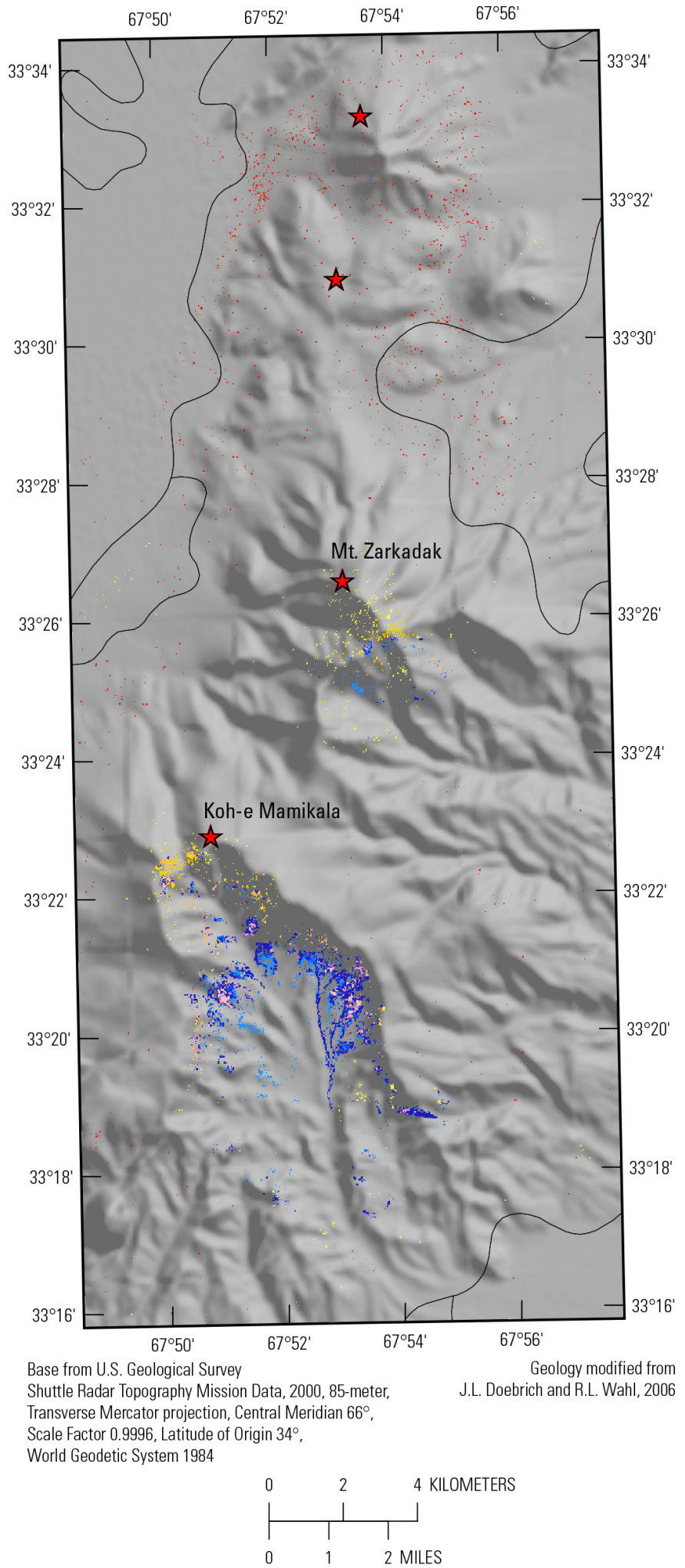

Figure 43. Map showing common alteration minerals derived from HyMap ${ }^{\mathrm{TM}}$ data and volcanoes in the Ghazni 2 area in Afghanistan (Kokaly and others, 2011, 2013). The detection of common alteration minerals is suggestive of possible past mineralization processes. 


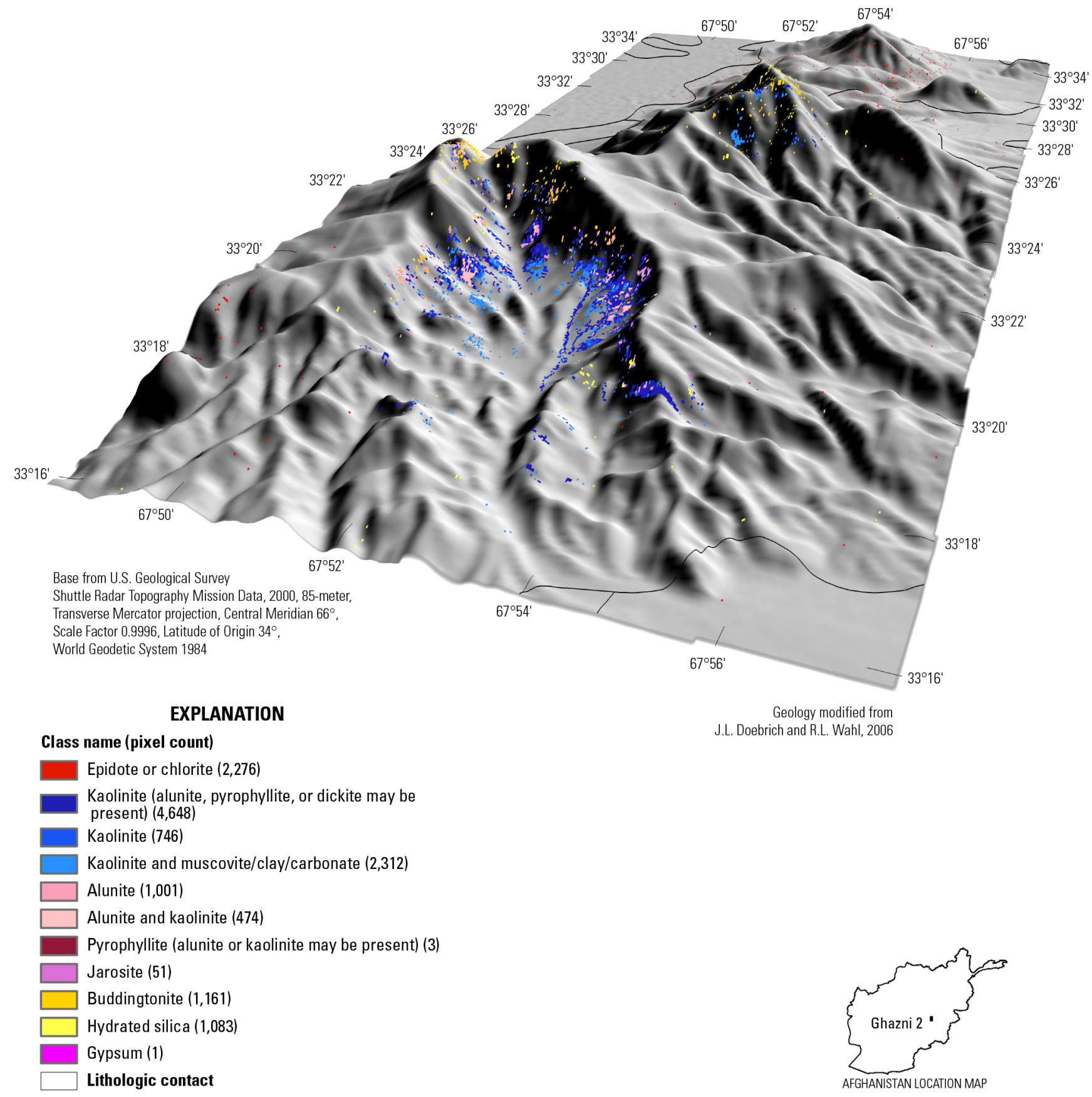

Figure 44. A three-dimensional image showing common alteration minerals derived from $\mathrm{HyMap}^{\mathrm{TM}}$ data overlain on a digital elevation model (Davis, 2007) in the Ghazni 2 area in Afghanistan (Kokaly and others, 2011, 2013).

Jarosite is also recognized in the iron-bearing minerals and other materials map (fig. 42) mixed with large volumes of goethitic minerals, hematite, and far lesser amounts of $\mathrm{Fe} 3+$ group minerals. The association of jarosite with alunite (an aluminous analog) suggests that both result from the secondary oxidation of base metal sulfides. 
A second volcanic center, Mt. Zarkadak, near $33^{\circ} 25^{\prime} 48.02^{\prime \prime} \mathrm{N}, 67^{\circ} 53^{\prime} 40^{\prime \prime} \mathrm{E}$, lacks the abundant alunite mapped in the breached volcano but buddingtonite and hydrous silica are mapped in association with widespread montmorillonite (figs. 39, 41, 43, and 44). As at Koh-e Mamikala, jarosite is also recognized in the iron-bearing minerals and other materials map (fig. 42) mixed with large volumes of goethitic minerals, hematite, and far lesser amounts of $\mathrm{Fe}^{3+}$ group minerals. Of particular note is that in this case there does not appear to be a close association of jarosite with alunite.

The two northernmost volcanic centers appear to be lower in elevation and smaller, and not as eroded and weathered as the two southern centers (fig. 40). Dry vegetation (fig. 41) and goethite minerals (fig. 42) are the primary materials mapped. However, low concentrations of epidote or chlorite class minerals and jarosite are dispersed throughout early Quaternary age rock units (figs. 43 and 44).

\section{Summary of Potential Mineralization}

The most significant mineral-resource potential in the study area is associated with the Quaternary volcanic rocks within the rift basin, although some potential also may exist in the Paleozoic rocks for industrial minerals.

The shallow level of alteration within the southern volcanic center and association with thermal waters in the basin (Abdullah and Chmyriov, 1977; Vikhter and others, 1978) suggest that mineralresource potential may include mercury, sulfur, and precious metal deposits. The alteration within the volcanic centers is reminiscent of solfataric alteration at other active systems where high-temperature magmatic-gas flow results in deposition of sulfur and mercury in fumarolic discharge zones and highsulfidation gold-copper deposits below the venting fumaroles (Henley and Berger, 2012, 2013). Porphyry copper deposits are also surmised to occur in these environments, but are most commonly formed at depths of 1.5 to $4 \mathrm{~km}$ beneath the volcanic vents (Henley and Berger, 2013). Siliceous sinter deposits peripheral to the centers of volcanism are indicative of near-neutral $\mathrm{pH}$ geothermal flow that may have deposited silica, clay, and mercury at the paleo-surface and gold, arsenic, and antimony within the upflow zones beneath the discharge vents (Henley and Ellis, 1983).

\section{Summary of Potential for Mineral Resources}

The potential for undiscovered ore deposits was evaluated in four areas: Bamyan 1, Farah 1, Ghazni 1, and Ghazni 2. The selection criteria for these areas were based on the integration of the recently acquired HyMap ${ }^{\mathrm{TM}}$ data that identified alteration mineral assemblages with supporting geological data. The HyMap ${ }^{\mathrm{TM}}$ data were the primary criteria/sources in the selection process because the alteration assemblages identify areas of hydrothermal activity that may have attendant ore deposition.

The Bamyan 1 area is located in Tertiary rocks towards the eastern end of the middle Afghanistan Farah Rud tectonic zone between the Herat fault zone on the north and the Helmand fault zone on the south. The Tertiary rocks are Eocene-Oligocene and Oligocene intermediate to silicic volcanic and associated sedimentary units that crop out in a fault-bounded block. Hyperspectral mineral mapping detected a discrete area of advanced argillic alteration consisting predominantly of silica, alunite, kaolinite, and pyrophyllite. The common association of this epithermal style of alteration with economic concentrations of copper and gold elsewhere and the size of the altered area makes the Bamyan 1 area permissive for the occurrence of precious and base metal deposits.

The Farah 1 area is located in Eocene to Oligocene volcanics and volcaniclastics and related intrusive rocks toward the western end of the middle Afghanistan Farah Rud tectonic zone between the Herat fault zone to the north and the Helmand fault zone the south. Hyperspectral mineral mapping 
shows discrete areas of structurally controlled, hydrothermal alteration that consists of predominantly muscovite, chlorite, and epidote. The common association of this style of alteration with economic concentrations of copper, zinc, lead, silver, and gold, the extent of the altered areas, and the occurrence of known polymetallic veins within the area, make the Farah 1 area permissive for the occurrence of vein-form precious and base-metal deposits.

The Ghazni 1 area is located in the northern part of Ghazni Province, Afghanistan, with a small section on the eastern edge in Wardak Province. The study area includes part of a north-south trending Quaternary volcanic field that transverses the Eocene-Oligocene Arghandab arc and part of a deformed tectonic unit that forms the back-arc region to the northwest of a volcano line. Hyperspectral data show that montmorillonite and hydrous silica are the primary alteration materials in the volcanic field and probably resulted from the weathering of volcanic tuffs. Potential in the area appears to primarily involve clay and aluminum resources in Paleozoic rocks and resources of gold, silver, mercury, and sulfur associated with hot springs.

The Ghazni 2 area is located in a mountainous region in central Ghazni Province, southeast Afghanistan. Remnant volcanic edifices are exposed in a generally north-south line that parallels the margins of a rift basin. Montmorillonite is the main weathering product of the volcanic ash and is hyperspectrally mapped in the volcanic edifices in the southern part of the field in association with the alunite group minerals, kaolinite, hydrated silica, and buddingtonite. The mineral alteration patterns within the volcanic centers and spatial association with thermal waters in the rift basin suggests that the mineral-resource potential is greatest for mercury, sulfur, and gold deposits.

Interpretation of HyMap ${ }^{\mathrm{TM}}$ and geologic data provide a firm foundation for further exploration in Bamyan 1, Farah 1, Ghazni 1, and Ghazni 2. 


\section{References Cited}

Abdullah, Sh., and Chmyriov, V.M., eds., 1977, Map of mineral resources of Afghanistan: Kabul, Ministry of Mines and Industries of the Democratic Republic of Afghanistan, Department of Geological and Mineral Survey, V/O "Technoexport" USSR, scale 1:500,000.

Abdullah, Sh., Chmyriov, V.M., Stazhilo-Alekseev, K.F., Dronov, V.I., Gannan, P.J., Rossovskiy, L.N., Kafarskiy, A.Kh., and Malyarov, E.P., 1977, Mineral resources of Afghanistan (2nd edition): Kabul, Afghanistan, Republic of Afghanistan Geological and Mineral Survey, 419 p.

Berger, B.R., 1986. Descriptive model of epithermal quartz-alunite Au, in Cox, D.P., and Singer, D.A., eds., Mineral deposit models: U.S. Geological Survey Bulletin 1693, p. 158.

Berger, B.R., and Henley, R.W., 2011, Magmatic vapor expansion and the formation of high-sulfidation gold deposits: Structural controls on hydrothermal alteration and ore mineralization: Ore Geology Reviews, v. 39, p. 75-90.

Berger, B.R., King, T.V.V., Morath, L.C., and Phillips, J.D., 2003, Utility of high-altitude infrared spectral data in mineral exploration: Application to northern Patagonia Mountains, Arizona: Economic Geology, v. 98, no. 5, p. 1003-1018.

Chirico, P.G., and Barrios, B., 2005, Void-filled SRTM digital elevation model of Afghanistan: U.S. Geological Survey Data Series 130.

Davis, P.A., 2007, Landsat ETM+ false-color image mosaics of Afghanistan: U.S. Geological Survey Open-File Report 2007-1029, 22 p.

Doebrich, J.L., and Wahl, R.R., comps., with contributions by Ludington, S.D., Chirico, P.G., Wandrey, C.J., Bohannon, R.G., Orris, G.J., Bliss, J.D., Wasy, A., and Younusi, M.O., 2006, Geologic and mineral resources map of Afghanistan: U.S. Geological Survey Open-File Report 2006-1038, scale $1: 850,000$.

Drenth, B.J., 2011, Notes on interpretation of geophysical data over areas of mineralization in Afghanistan: U.S. Geological Survey Open-File Report 2011-1258, 13 p.

Henley, R.W., and Berger, B.R., 2011, Magmatic-vapor expansion and the formation of high-sulfidation gold deposits: Chemical controls on alteration and mineralization: Ore Geology Reviews, v. 39, p. $63-74$.

Henley, R.W., and Berger, B.R., 2012, Pyrite-sulfosalt reactions and semimetal fractionation in the Chinkuashih, Taiwan, copper-gold deposit: A 1 Ma paleo-fumarole: Geofluids, v. 12, no. 3, p. 245260.

Henley, R.W., and Berger, B.R., 2013, Nature's refineries-Metals and metalloids in arc volcanoes: Earth-Science Reviews, v. 125, p. 146-170.

Henley, R.W., and Ellis, A.J., 1983, Geothermal systems ancient and modern: A geochemical review: Earth-Science Reviews, v. 19, no. 1, p. 1-50.

Henderson, G.V., 1970, The origin of pyrophyllite rectorite in shales of north central Utah: Clays and Clay Minerals, v. 18, p. 239-246.

King, T.V.V., Johnson, M.R., Hubbard, B.E., and Drenth, B.J., eds., 2011a, Identification of mineral resources in Afghanistan-Detecting and mapping resource anomalies in prioritized areas using geophysical and remote sensing (ASTER and HyMap) data: U.S. Geological Survey Open-File Report 2011-1229, 327 p.

King, T.V.V., Kokaly, R.F., Hoefen, T.M., Dudek, K.B., and Livo, K.E., 201 1b, Surface materials map of Afghanistan: Iron-bearing minerals and other materials. U.S. Geological Survey Scientific Investigations Map 3152-B, scale 1:1,100,000. 
Kokaly, R.F., 2011, PRISM: Processing routines in IDL for spectroscopic measurements (installation manual and user's guide, version 1.0): U.S. Geological Survey Open-File Report 2011-1155, 432 p.

Kokaly, R.F., King, T.V.V., and Hoefen, T.M., 2013, Surface mineral maps of Afghanistan derived from HyMapTM imaging spectrometer data, version 2, U.S. Geological Survey Data Series 787.

Kokaly, R.F., King, T.V.V., Hoefen, T.M., Dudek, K. and Livo, K.E., 2011, Surface materials map of Afghanistan: Carbonates, phyllosilicates, sulfates, altered minerals, and other materials. U.S. Geological Survey Scientific Investigations Map 3152-A, scale 1:1,100,000.

Kokaly, R.F., King, T.V.V., and Livo, K.E., 2008, Airborne hyperspectral survey of Afghanistan 2007: Flight line planning and HyMap data collection: U.S. Geological Survey Open-File Report 2008$1235,14 \mathrm{p}$.

MacDonald, G.A., 1944, Solfataric alteration of rocks at Kilauea volcano: American Journal of Science, v. 242, no. 9, p. 496-505.

Montenat, C., 2009, The Mesozoic of Afghanistan: GeoArabia, v. 14, p. 147-210.

Mosier, D.L., Singer, D.A., and Berger, B.R., 1986, Descriptive model of Comstock epithermal veins, in Cox, D.P., and Singer, D.A., eds., Mineral deposit models: U.S. Geological Survey Bulletin 1693, p. $150-151$.

Papke, K.G., 1969, Montmorillonite deposits in Nevada: Clays and Clay Minerals, v.17, p. 211-222.

Peters, S.G., King, T.V.V, Mack, T.J., Chornack, M.P., eds., and the U.S. Geological Survey Afghanistan Mineral Assessment Team, 2011, Summaries of important areas for mineral investment and production opportunities of nonfuel minerals in Afghanistan: U.S. Geological Survey Open-File Report 2011-1204, 1,810 p. plus appendixes on DVD.

Peters, S.G., Ludington, S.D., Orris, G.J., Sutphin, D.M., Bliss, J.D., Rytuba, J.J., eds., 2007, Preliminary non-fuel mineral resource assessment of Afghanistan 2007: U.S. Geological Survey Open-File Report 2007-1214.

Ruleman, C.A., Crone, A.J., Machette, M.N., Haller, K.M., and Rukstales, K.S., 2007, Map and database of probable and possible Quaternary faults in Afghanistan: U.S. Geological Survey OpenFile Report 2007-1103, 39 p., 1 plate.

Tapponnier, P., Mattauer, M., Proust, F., and Cassaigneau, C., 1981, Mesozoic ophiolites, sutures, and large-scale tectonic movements in Afghanistan: Earth and Planetary Science Letters, v. 52, p. 355-371.

Thompson, A., Scott, K., Huntington, J., and Yang, K., 2009, Mapping mineralogy with reflectance spectroscopy; examples from volcanogenic massive sulfide deposits: Reviews in Economic Geology, eds., Bedell, R., Crosta, A.P., and Grunsky, E., v. 16, p. 25-40.

Vikhter, B.Ya., Yeremenko, G.K., Chmyrev, V.M., and Abdulla, D., 1978, Pliocene-Quaternary volcanism of Afghanistan: International Geology Review, v. 20, p. 525-536.

Wheeler, R.L., Bufe, C.G., Johnson, M.L., and Dart, R.L., 2005, Seismotectonic map of Afghanistan, with annotated bibliography: U.S. Geological Survey Open-File Report 2005-1264, 31 p.

Wittekindt, H., and Weippert, D., 1973, Geologic map of central and southern Afghanistan: German Geological Mission in Afghanistan, scale 1:500,000. 